Max-Planck-Institut

für ausländisches und

internationales Strafrecht

\title{
International Max Planck Research School on Retaliation, Mediation and Punishment
}

\section{IMPRS REMEP 2008 - 2011}

\section{Speaker's Report}

On the occasion of the evaluation of the International Max Planck Research School on Retaliation, Mediation and Punishment (IMPRS REMEP) scheduled for Wednesday, 1 February 2012, at the Max

Planck Institute for Foreign and International Criminal Law, Freiburg. 
A. GENERAL INFORMATION

1. Introductory Note

2. Scientific Subject of the IMPRS REMEP

3. The Organization of the IMPRS REMEP

4. Communication

5. Partner Institutions

6. International Co-operations

B. PROGRAM OF THE IMPRS REMEP

1. Thesis Supervision

2. Curriculum \& Table of Events 2008-2011

3. REMEP Conferences, Workshops, Guest Lecture Series

4. Activities by REMEP Students

5. Research Facilities

C. STUDENT BODY

1. Recruitment Procedure

2. Academic Provenance and Nationality of the Student Body

3. Duration of Doctoral Research Projects \& Results Achieved

4. Doctoral Students

5. Personal Statements 
D. ADDITIONAL CONSIDERATIONS

1. Motivations for Joining the IMPRS REMEP

2. REMEP University Partners' Commitment to a Continued Cooperation

3. Doctoral Exams \& Language Issues

4. Alumni

E. SPONSORSHIP \& FINANCIAL INFORMATION

\section{F. APPENDICES}

1. Doctoral Research Projects

2. Members of Executive Committee and Teaching Faculty

3. University Partnership Declarations

4. Program: Conference on Retaliation

5. Application Requirements 
A. General Information 


\section{Introductory Note}

The International Max Planck Research School on Retaliation, Mediation and Punishment (IMPRS REMEP) is a research and teaching network for doctoral studies. It focuses on the role of retaliation, mediation and punishment for social order and peace in society, which constitutes a fundamental question common to the fields of sociology, social anthropology, history, jurisprudence and political science.

The Research School was founded in January 2008 and started its curricular activities in April 2008. Up until now, 33 doctoral students from Germany and abroad have been admitted to the Research School. The end of this (first) funding period will be 31 December 2013. The IMPRS REMEP is one of currently more than sixty International Max Planck Research Schools under the umbrella of, and funded by, the Max Planck Society for the Advancement of Science (MPS) and numerous German universities. Most of the Research Schools are within the areas of chemistry, physics and technology as well as biology and medicine (75\%). The IMPRS REMEP is one of currently only six Research Schools within the Human and Social Science Section with a focus on law. The
Research Schools are established for an initial six year period after successful evaluation of the research proposal by a committee involving representatives of the Max Planck Society and the Association of Universities and other German Education Institutions. Depending on the recommendation by external expert reviewers after four years, the Research School may be extended for a second funding period of another six years (in case of the IMPRS REMEP this would be 2014-2020).

The IMPRS REMEP is unique in its set-up, as it builds on the capacities of four Max Planck Institutes and two universities creating synergies necessary to conduct first class interdisciplinary research on the multi-faceted and crosscultural area of study on retaliation, mediation and punishment: the Max Planck Institute for Comparative Public Law and International Law (Heidelberg), the Max Planck Institute for European Legal History (Frankfurt), the Max Planck Institute for Foreign and International Criminal Law (Freiburg) and the Max Planck Institute for Social Anthropology (Halle), as well as the University of Freiburg and the Martin Luther University of Halle-Wittenberg. 


\section{Scientific Subject of the IMPRS REMEP}

\section{Rationale and Output}

REMEP addresses retaliation, mediation, and punishment and their role in establishing, maintaining, and forming social order in the face of conflicts, various forms of crime, terrorism, insurgencies, or civil war. At the same time, globalization, the internationalization of politics, and migration all result in new arenas of conflict and novel answers to deal with such conflicts. As such, REMEP slots smoothly into the scientific fields studied at the Max Planck Institutes in Halle, Heidelberg, Freiburg, and Frankfurt, as well as the Law School of Freiburg University and the Halle University based Seminar for Social and Cultural Anthropology. REMEP adopts an approach that is comparative and multidisciplinary; it is focused on the creation of added scientific value by building bridges between disciplines. History of law, international law, criminal law, criminology, and anthropology analyze REMEP through different lenses, at different periods of time, and on the basis of different bodies of theory and methods.

Through the lens of international (criminal) law, the focus is placed on the state and international relations. The special set of international rules developed to deal with conflicts arising between states refers to procedures of mediation and retaliatory acts recognized or outlawed by international law, moreover to mechanisms vested in the UN Security Council. Due to an assumed responsibility to protect, the scope of local conflicts with the potential to become internationalized has widened. In addition, since the early 1990s, international crimes have recaptured policy and legal attention. A normative and political framework of international criminal justice has emerged: this framework has not only drawn international law and international relations closer to criminal law and towards the body of theories that explain criminal punishment, but has also redrawn its limits, particularly in the face of the fading salience of national borders. Criminology emphasizes the study of comparative costs and benefits of formal punishment and alternative forms of punishing and doing justice, governance through punishment, regulatory norms, and self control; furthermore, it explores conflicts and conflict resolution in social settings alienated from, or not accessible to, state based formal control.
History of law places the focus on the development of a state based, formal system of punitive control, the formation of institutions of criminal justice, and the ensuing relationship between social sanctions and criminal punishment. Anthropology has a vested interest in the social significance of REMEP in processes of interaction between different models of normative and institutional ordering, particularly, though not limited to, segmentary and acephalous societies. Segmentary and acephalous societies may - to some extent - also provide a model for international relations and law in global contexts. After all, in the absence of a world government at the global level, the world is an acephalous society. At this level we find different forms of law and legal institutions, but no global law-enforcement agency independent of lower, e.g., national levels of organization. In such a context, power imbalances, power differences, and the workings of retaliatory logic have to be approached from a social science perspective. Originally, this perspective was inspired by the study of acephalous societies, but it also needs to be applied to relations between states, relations between groups, or relations in the sphere of negotiations in the "shadow of the state."

Each of the disciplines adds a special set of skills to the whole. While criminology contributes theory and research based primarily on quantitative methods and a field of research closely connecting normative and social sciences, anthropology provides a focus on the actor, theories of action, and qualitative and interpretive methods, as well as a specialization in a research field where a power monopoly and state institutions are absent, distant, or weakened. Criminal and international law studies open the way for an analysis of strongly formalized procedures, the structure, content, and meaning of normative discourses, as well as their role in the formation of criminal and international policies and institutions. History of law provides for methodological expertise and rich experiences through text analysis and the interpretation of long term social and legal processes.

The output of the first three and a half years of REMEP brought about the full implementation of the training program, a coherent body of $\mathrm{PhD}$ projects, the finalization (or close to finali-

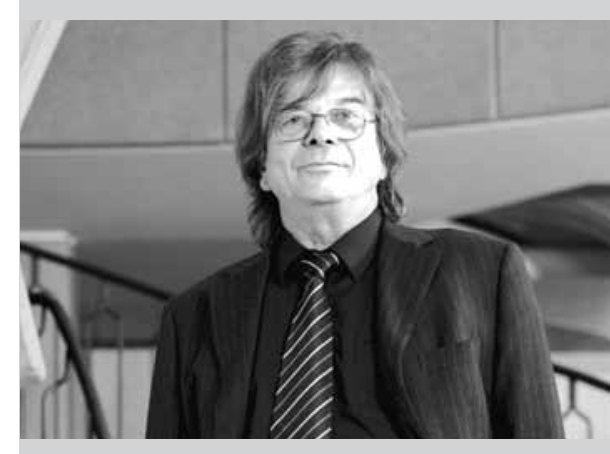

Prof. Dr. Dr. h.c. Hans-Jörg Albrecht, Director at the Max Planck Institute for Foreign and International Criminal Law and Speaker of the International Max Planck Research School on Retaliation, Mediation and Punishment 
zation) of some 15 dissertations, the unfolding of the scientific program, and a first milestone in the form of a conference on retaliation.

\section{Interdisciplinary Subjects and Innovation of Subjects}

The inter-/multidisciplinary approach adopted in REMEP is pursued and implemented along different strands.

\section{Training and curricula development}

A common curriculum introduces students attached to REMEP to theory, methods, and research as represented in the four MPIs and the two Universities. The courses provided at each institute offer basic training and are geared towards a multi-disciplinary body of students.

\section{A framework for interdisciplinary dialogue and continued exchange}

Winter and summer universities provide a framework for the presentation and discussion of PhD projects. In all the disciplines involved in REMEP, project outlines and results are placed under the review and scrutiny of both REMEP students and senior researchers.

\section{A network of scientists and research institutes dealing with REMEP}

All institutes involved in REMEP are active in developing a network of scientists and research institutes with an interest in the core questions of the Research School. To this end, internationally renowned scientists and professionals are invited to give lectures or hold workshops (which are open for all REMEP students). One such example was a workshop organized by John Braithwaite in 2009, where he presented his work on violent conflicts and peacemaking in SouthEast Asia. The aim of these lectures and workshops is to create a scientific network with REMEP as a central node.

\section{Integration of research and scientific} advances

The October 2011 conference "On Retaliation” brought together REMEP students, REMEP senior researchers, and international scientists in an inaugural event devoted to the review and summary of past and ongoing research. Follow up conferences are planned to occur at regular intervals.

\section{Topic Based Overlap of Dissertations}

The topic based overlap of dissertation projects is significant. The PhD projects of REMEP can be collapsed into five clusters which, on the one hand, create a distinct profile and, on the other hand, demonstrate the synergetic potential of the program.

\section{Cluster 1: Criminal Punishment, Retaliatory Violence, Interactions, and Social Order}

At the center of the research in this cluster we find interactions between formal criminal law responses and (retaliatory) violence. A study of "Jihadi violence" analyzes texts produced and distributed by terrorist groups and the narratives of why and how the application of violence is legitimate, functional, and necessary. Research on the Maratruchas in three Latin American countries focuses on the role of retaliatory gang violence and the impact various forms of official punitive and administrative responses can have. Closely related to this $\mathrm{PhD}$ is a study that concentrates on the role of violence in the informal economies and social orders of the Favelhas of Rio de Janeiro. Criminal law responses to honor killings in Germany provide an opportunity to look into how such motives (referring to retaliation, informal norms, and cultural differences) are construed. Interactive processes are dealt with under the research title of "Ethnographies of contentious criminalization" in three regions displaying territorial, separatist, and environmental conflicts. Legal responses to the Saxon Peasant Uprising of 1790 are analyzed, as are land-based conflicts and their settlement in Eastern Sudan.

\section{Cluster 2: Mediation and Reconciliation in Comparative Perspectives}

This cluster assembles $\mathrm{PhD}$ projects which focus on a comparative perspective and on the role of mediation, reconciliation, and consent as seen from the angle of strictly formalized procedures and plural legal orders. The emergence of informal norms justifying sentence bargaining in German criminal proceedings is studied, as is the insertion of mediation in the criminal process of countries displaying different legal cultures (Taiwan, mainland China, and Germany). A third study addresses the dynamics of dispute processes in plural legal orders in South Africa and Swaziland. 
Another angle of the relationship between punishment and reconciliation emerges with the analysis of the development of rules in Europe to protect the honor and dignity of convicted persons against elements of criminal punishment that stigmatize and socially exclude.

\section{Cluster 3: Violent Pasts, Transition, and Vario-} us Roads to Justice and Social Order

The third cluster assesses REMEP from violent pasts and/or from significant economic and political transitions; it also analyzes the various roads which might be taken when re-establishing social order and ascertains acceptable ways of delivering justice and dispute settlement. Such questions are addressed in regions where the state is either weak or virtually non-existent. Projects in a post-war region of Sudan and amidst uncertainty in Afghanistan place a focus on disputes and dispute settlement on the ground and in communities, while the Northern Uganda conflict is studied under the perspective of how retributive and restorative approaches interact in a situation which was internationalized through a referral to the International Criminal Court. The role of various non-state actors and the invocation of rights are discussed in studies on "Rights-Based Activism in Rwanda," "Transitional Justice from Below in Colombia," and "Negotiating Justice in Post-Ba'ath Iraq." These projects focus on actors, interest groups, and victims, as well as the use of national/international human rights law in the process of negotiating and implementing peace and delivering compensation. The process and outcome of organizing accountability and criminal justice through community based institutions are studied in post transition South Africa: a country still deeply divided along ethnic lines with vast inequality. Finally, Mongolia offers an interesting opportunity to study the transition from an authoritarian criminal justice system to a system which falls in line with European and international normative standards.

\section{Cluster 4: Punishment and Interactions} between Concepts of International and Local Orders

The fourth cluster centers around the international legal and policy framework and its interactions with national and regional/local levels. A project on "The Politics of Order" analyzes the notion and meaning of punishment in international law. An interest in answers to questions of how local, national, and international levels of formal justice interact, guides projects on the role of criminal law in reconstructing social order in Bosnia-Herzegovina, Croatia, and Serbia and the referral practices and patterns observed in the ICTY and the ICTR. Interactions between local conflicts and international mechanisms are examined in the field of international arrest warrants issued during ongoing and large scale violence; the study of the potential of international criminal law to protect minorities is addressed in a project on the role of the European Court on Human Rights as an external actor in resolving transitional conflicts that have arisen out of Latvian approaches towards the country's Russian minority. China's position towards the International Criminal Court and the Rome Statute is analyzed from the perspective of legal culture and the responsiveness of legal cultures to international criminal laws that express a vision of international order. Finally, a look back to war crimes trials in the French Occupation Zone in Germany (1945-1953) re-examines the onset of international criminal law practices.

\section{Cluster 5: Punishment, Social Control, Regu- lation, and Governance}

The fifth cluster is comprised of studies that deal with the interplay between legal, economic, and political rationalities in the regulation of corporate crime and how such processes form corporate criminal law and shape its practice. Interactions between criminal law, administrative regulations, and modes of self-control are analyzed in a project that looks at the control of money laundering. The emerging interplay between the private and public in the field of border and immigration control and its potential for vigilantism are studied at the US-Mexican Border.

The clusters are open and lend themselves to cross referencing between individual projects and to the building of advanced theories on retaliation, mediation, and punishment. They demonstrate the significant variance in the phenomenon described by central concepts, such as the state, conflict, actors, methods, and 
interaction. This variance is necessary to build knowledge and to test assumptions that go beyond the scope of individual projects. Each cluster is comprised of students from all participating institutes.

Particular projects from the first and third cluster have necessitated the design and implementation of measures for risk monitoring and control. Field research in violence prone areas carries particular risks. In cooperation with the Max Planck Society, a risk management scheme was developed by the REMEP coordinator. This scheme can be adjusted to the concrete situation in various research fields and includes a comprehensive discussion of the risks involved, advice as to how to respond to risks, the provision of designated contact points, and communication at regular intervals.

\section{Output and Quality in Comparison to "Standard Dissertations"}

Based on formal results of finalized $\mathrm{PhDs}$, it is not yet possible to provide a firm picture of whether a difference exists. That said, the grades of the first three PhDs submitted in Freiburg were outstanding.

As has been shown through the clustering of PhDs, the output will appear as a cohesive body of research and literature. The output certainly is characterized by the theoretical and methodological input as well as by the framework established to sustain exchange and academic guidance.

The output measured in the form of contributions to national and international conferences, the organization of workshops, and the publication of articles which flow from ongoing research is certainly far above what can be observed for "standard dissertations." This is well documented by the impressive listings of conference papers and publications that can be found in the personal home pages of the REMEP students.

\section{IMPRS REMEP - Local Perspective}

The $\mathrm{PhD}$ projects of the doctoral students in Frankfurt and Heidelberg are related to the scientific agenda of these Max Planck Institutes and integrated in their respective research fields.

\section{Freiburg}

The first wave of REMEP PhD students in Freiburg who enrolled in spring 2008 have either finalized their $\mathrm{PhDs}$ or are in the last stage of doing so. One student has fully graduated, two students will take the final PhD exams in January/February 2012, and three students are expected to take the final exams during the summer term of 2012.

The Freiburg REMEP students contribute to all of the abovementioned clusters; they have developed into a cohesive unit and present themselves as a distinct research group. The group has demonstrated its commitment through the organization of lecture series, workshops and discussion groups, and special events. The scientific output is visible in publications and lectures at national and international conferences. They have provided input to American Society of Criminology meetings and have contributed to the annual conferences of the European Society of Criminology. Such activities create conditions well suited to foster ongoing discussions and the exchange of ideas in the group.

The synergetic effects of REMEP can be easily demonstrated. The systematic consideration of retaliation, mediation, and punishment - coupled with the Research School's multidisciplinary approach - exposes aspects and possible consequences of (criminal) punishment which hide behind formal procedures and deeply entrenched assumptions on the legitimacy and effectiveness of state based punitive responses. Legal history, international relations, and anthropology have synergetic effects in terms of adding and modifying research questions and hypotheses and providing a different view on concepts firmly established in criminal law and criminology. The Freiburg REMEP students also profit from the expertise on qualitative methods and interpretive access available through ethnology. This has, in particular, enhanced studies on sentence bargaining and Jihadi violence and will result in adding qualitative methods to the Freiburg based training courses through expertise available at the Freiburg Institute of Sociology.

\section{Halle*}

REMEP PhD students in Halle, being fully integrated in different research units at the MPI and SSCA, have developed a strong internal cohesion and REMEP identity and have adopted 
an academic culture of comparative and interconnected research. The nine $\mathrm{PhD}$ projects are at different stages. They all revolve around the basic REMEP agenda and are intertwined through their orientation towards a number of basic concepts. Dimensions of disputing in connection with trans-scale arrangements (local - state - transnational), competing concepts of order and the problem of securitization politics in connection with divergent concepts of justice are addressed throughout all projects in Halle. Thus the basic sequence of the IMPRS Retaliation - Mediation - Punishment is contextualized and pushed to further theorizing both from an anthropological perspective as well as through a transdisciplinary lens. The totality of projects covers two research areas, one is South and East Africa the other the Greater Middle East.

Those students in the final stage of their doctoral projects have developed with support of the Halle group coordinator a series of initiatives to present their research results to the academic community. Apart from other activities, three of them attended the Congress 'Living Realities of Legal Pluralism' organized by the Commission on Legal Pluralism together with the Centre for Legal and Applied Research (CLEAR) and the Research Chair in Customary Law and the Chair for Comparative Law in Africa, at the University of Cape Town, South Africa in September 2011. The active attendance of Halle REMEPs at the International REMEP Conference 'On Retaliation' in October 2011 at the MPI in Freiburg was also a great success. Moreover, the students have taken up the initiative to self-organize a panel at the Annual Meeting of the American Law and Society Association in 2012.

\section{Benefits from Transdisciplinary Cooperation}

Apart from that cooperation synergy effects by far transcend the framework of the Halle group. Some of the common fields of interest that proved to attract $\mathrm{PhD}$ students across the contributing MPIs - and which have led to stimulating debates - are narratives and politics of memorization, processes of law production and competing concepts of justice.
So, the cooperation with criminologists, historians of law, experts in criminal law and international law brings a fresh input to anthropological research on global and transnational processes, e.g. on ongoing processes of an increasing transnationalisation of law and its consequences. This allows for a widened scope on translocal and transnational interactions.

Since the establishment of IMPRS REMEP this ambitious project seems to be on the right track in order to generate the epistemological benefits sought by all contributing disciplines. The first and foremost advantage materializes in a mutual sensitising process that allows students and faculty members to avoid mutual misunderstandings resulting from different terminologies and prioritisations of perspectives while doing research on the same or comparable topics. There is not only a growing interest in each other's trajectory; also an approximation in the sense of an identification of analytical overlaps or the possible adoption of new perspectives manifests in the research projects. In the course of time a number of overarching topics has been identified, such as the impact of global governance institutions, especially the International Criminal Courts (ICCs), the impact of transnational securitization politics, or the importance of global financial flows for the management of conflict. Also in regard to methodological issues interesting dynamics evolved. Jurisprudential projects increasingly adopt an empirical component and also take the social working of law into consideration, while anthropological research accepts the transformation of social realities into normative texts as an indispensable component which proves to be accessible through anthropological theory. Logics of retaliation and compensation have been controversially discussed with respect to the role of the state and its institutions in the maintenance of order and in relation to differing social conditions. The best proof for this progress is the agenda of the transdisciplinary conference on retaliation mentioned above.

\section{* Dr. Bertram Turner, Senior Researcher,} Max Planck Institute for Social Anthropology

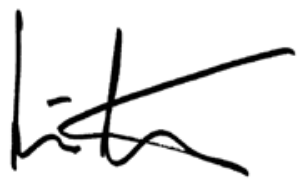

Prof. Dr. Dr. h.c. Hans-Jörg Albrecht

Freiburg, 13 January 2012 


\section{The Organization of the IMPRS REMEP}

Prof. Dr. Dr. h.c. Hans-Jörg Albrecht, Director at the Max Planck Institute (hereafter MPI) for Foreign and International Criminal Law, Freiburg, is Speaker and Dean of the IMPRS REMEP. He represents the Research School and chairs its Executive Committee. Deputy is Prof. Dr. Günther Schlee, Director at the MPI for Social Anthropology, Halle (Saale). The main tasks of the Executive Committee of the IMPRS REMEP are to direct and supervise all academic and administrative activities, and to take all important financial decisions. Hence, it is responsible for all major policy decisions, the formal admission of doctoral students to the program, the overall organization of the training activities as well as the evaluation of the students and their research projects. The Executive Committee meets at least once a year, usually, at one of the IMPRS locations.

Apart from the speaker and his deputy, the Executive Committee is made up of members of each of the six institutions participating in the IMPRS REMEP:

- Prof. Dr. Franz v. Benda-Beckmann, head of the "Project Group Legal Pluralism" at the Max Planck Institute for Social Anthropology;

- Prof. Dr. Keebet v. Benda-Beckmann, head of "Project Group Legal Pluralism" at the Max Planck Institute for Social Anthropology;

- Prof. Dr. Thomas Duve, Director at the Max Planck Institute for European Legal History, Frankfurt, succeeded Prof. Dr. Dr. h.c. mult. Michael Stolleis;

- Prof. em. Dr. Wolfgang Frisch, Director of the Institute for Criminal Law and Legal Theory at the Faculty of Law, University of Freiburg;

- Prof. Dr. Roland Hefendehl, Director of the Institute for Criminology and Business Criminal Law at the Faculty of Law, University of Freiburg;

- Prof. Dr. Walter Perron, Chair for Criminal Law, Criminal Procedure and Comparative Criminal Law at the Faculty of Law, University of Freiburg;

- Prof. Dr. Richard Rottenburg, Director of the Institute of Social Anthropology at the Faculty of Philosophy, Martin Luther University Halle-Wittenberg;

- Prof. Dr. Dr. h.c. mult. Ulrich Sieber, Director at the Max Planck Institute for Foreign and International Criminal Law, Freiburg;

- Prof. Dr. Dr. h.c. Rüdiger Wolfrum, Director at the Max Planck Institute for Comparative Public Law and International Law, Heidelberg;

until July 2010:

- Prof. em. Dr. Dr. h.c. mult. Michael Stolleis, Director at the Max Planck Institute for European Legal History, Frankfurt;

The Research School Office is located at the Max Planck Institute for Foreign and International Criminal Law in Freiburg. Dr. Carolin F. Hillemanns is in charge of the coordination of the IMPRS REMEP. She assists the Executive Committee in its work and the IMPRS RE-

MEP students in overall curricular and administrative issues. At all IMPRS locations, senior research scientists function as local coordinators and are in charge of the implementation of the REMEP training program.

\section{Local Scientific Coordinators / Teaching Faculty:}

- Prof. Dr. Karl Härter, Senior Research Scientist, and PD Dr. Miloš Vec, Senior Research Scientist at the Max Planck Institute for European Legal History, Frankfurt;

- Dr. Carolin Hillemanns, IMPRS REMEP Coordinator and Dr. Michael Kilchling, Senior Research Scientist at the Max Planck Institute for Foreign and International Criminal Law, Freiburg;

- Dr. Pietro Sullo, Senior Researcher at the Max Planck Institute for Comparative Public Law and International Law, Heidelberg;

- Dr. Bertram Turner, Senior Research Scientist at the Max Planck Institute for Social Anthropology, Halle (Saale). 


\section{Communication}

Efficient communication within the IMPRS REMEP is key, especially given the four locations of the partners. The Executive Committee and the local coordinators meet in person once a year in order to discuss and decide all important curricular, administrative and financial decisions. The heads of administration of the respective Institutes make quarterly reports to the Research School office. The local coordinators communicate on a regular, at times weekly basis, either via email or telephone. At each REMEP location the student body and the local coordinator get together in group meetings. One-on-one meetings are held whenever needed.

The preferred method of communication among the Executive Committee as well as with the student body is email (via mailing groups or individually) on a need-to-know basis. Furthermore, all relevant documents both for the Executive Committee as well as for the student body are made available online. The REMEP web page has an extra- and an intranet environment featuring the personal homepages of everyone involved, data regarding the research projects of the doctoral students, a REMEP event calendar, basic information such as rules on good scientific practices, post-doc positions

\section{Partner Institutions}

\section{Freiburg}

Criminal law studies at Freiburg University School of Law focus on legal theory, comparative legal studies and (international) commercial criminal law. These three fields are closely linked with each other. In line with this strategy, research in legal theory focuses mainly on the analysis of the supranational foundations for legitimating criminal law whereas comparative legal sciences study and compare specific regulations and the structural fundaments of regulation systems. Historical and philosophical aspects constitute the starting point for these considerations. The close cooperation with the MPI Freiburg ensures additional synergetic effects. Studies in (international) commercial criminal law concentrate on challenges and problems of criminal law occurring in a globalized and transnational economy. Re- and important practical information for the student body, ranging from health insurance issues to language classes. Course information packs as well as protocols and budget information are made available on the IMPRS REMEP intranet page, which is password protected to ensure privacy and confidentiality.

$58 \%$ of the doctoral students judge the flow of communication with their respective supervisors very positively (15\% excellent, $15 \%$ very good ( 5 responses respectively) and $27 \%$ good (9 responses)) while 15\% are satisfied and $6 \%$ (2 responses) are unsatisfied, leaving $21 \%$ with no answer. $76 \%$ of the responses by the students were very favorably in regards to receiving necessary and useful information by the REMEP student office ( $42 \%$ very good ( 14 responses), 33\% good (11 responses)), leaving 9\% (3 responses) unsatisfied and 15\% (5 responses) with no answer.

$64 \%$ (21 responses) of the doctoral students judge the communication amongst the student body as excellent and another $12 \%$ (4 responses) as good, while 6\% (2 responses) felt it was unsatisfactory, leaving 18\% (6 responses) with no answer.

search is based on legal theory, comparative legal studies and the empirical basis of criminal law; it profits greatly from the interaction with the MPI Freiburg. Because of the importance of basic research, comparative legal studies and (international) commercial criminal law, the University of Freiburg created a completely new branch of criminal law studies. Additionally there is intensive research in the fields of criminal processes as well as criminal sanctions and sentencing, which are of great importance in criminal practice.

The MPI Freiburg (criminal law and criminology) is dedicated to comparative normative and empirical research in the fields of crime, criminal law and criminal justice. The Institute consists of the Department of Criminal Law (Ulrich Sieber) and the Department of Crimi- 
nology (Hans-Jörg Albrecht). Placed at the intersection between law and social sciences with a strong comparative focus, the research agenda of the MPI Freiburg is interdisciplinary in scale and international in scope. On this basis, both departments work together to address normative and empirical questions of crime, national, supranational and international crime control policies and criminal law. The goal is to understand the interdependencies of crime, crime control and criminal law as well as to support worldwide the reform of criminal law and crime control policies. The broad disciplinary scale and scope of the research agenda of the MPI Freiburg is reflected by the multidisciplinary and international composition of the Institute's staff, which is comprised of lawyers, sociologists and psychologists from different countries in and outside Europe. This interdisciplinary environment is facilitated by an international structure whereby the major regions of the world are divided for the purpose of study into country sections. Within this structure, the expertise of many decades of comparative research on criminal justice systems of the world has been accumulated. Present projects of the MPI Freiburg related to the topic of the IMPRS REMEP scientific agenda and training focus on the death penalty, hate crimes, drug markets, organized crime, terrorism and victims of war as well as on criminal law and state crime, honor and criminal law, the implementation of the Statute of the International Criminal Court and conflict resolution strategies in different cultural settings.

Doctoral students at the MPI Freiburg in the Department of Criminal Law graduate with a doctoral degree "Dr. iur." at the Faculty of Law of the University of Freiburg where the Directors of the MPI Freiburg hold an honorary professorship. Both Directors participate in the curriculum of the Faculty of Law lecturing each semester on criminology and specific fields of criminal law, holding seminars and participating in exams at the undergraduate, graduate and postgraduate level. At the same time, two of the professors of criminal law who hold chairs at the University of Freiburg participate in the IMPRS (Wolfgang Frisch, Walter Perron) and are external members of the Max Planck Society. In the Department of Criminology approximately two thirds of the doctoral students graduate with the "Dr. iur." title because criminology is based within the Faculty of Law of the University of Freiburg (like in most other universities in Germany). Depending on the individual educational background, doctoral students are also graduated by the Departments of Sociology at the Faculty of Philosophy to which the Director of the Department of Criminology at the MPI (Hans-Jörg Albrecht) belongs as a member. On this basis, all disciplines that are of relevance for research at the MPI Freiburg can be integrated in the doctoral education. Of major importance for the training of doctoral students at the MPI Freiburg is the IMPRS on Comparative Criminal Law jointly run by the Faculty of Law at the University of Freiburg since 2006.

\section{Frankfurt}

Since its foundation in 1964, the Max Planck Institute for European Legal History has been dedicated to basic research from a historical perspective in the field of law. The Institute uniquely combines the knowledge of its experts and expertise on the history of law in Byzantine and Roman Europe in Late Antiquity and the Early Middle Ages, and the ius commune of the High and Late Middle Ages along with the history of private, criminal, public and church law in the early modern era and current age. The scope of historical analysis of law transfer processes, the interaction between law and other normative systems in a historical context as well as self-organization and law is becoming ever broader. A particular challenge embraced by the Institute in cooperation with other Institutes of the Max Planck Society is to create historical and empirical bases for a critical study of the system of law in a globalized world. To this end, the Institute is paying increasing attention to the interrelationships between European and non-European legal systems. The comparative dimension of research into legal history is also becoming increasingly significant. The Institute is headed by Managing Director, Thomas Duve. A team of permanent scientific staff are engaged in numerous research projects that are amalgamated in seven areas of research focus and two special research fields. The Institute also continues to dispose over expertise acquired in research projects completed in meanwhile eight competence areas.

Current projects of particular interest for the topic of the IMPRS scientific agenda and training deal with the history of crime and criminal justice, focusing on the normative construction and prosecution of deviance, the development of state based systems of formal punitive con- 
trol and the politics of public order and public security from the Late Middle Ages to the early 20th century. Specific projects explore the media's representation of crime and punishment, the origins and establishment of criminology and criminal research, the legal responses to political crime and the formation of transnational prosecution regimes from the 18th century onward.

With visiting scientists, doctoral students and post-docs, as well as a large number of researchers from abroad, a grant program including the option of accommodation on the premises, participation in international graduate schools and links with cooperating partners in Germany, the Institute is a reference point for the national and international scientific community. Doctoral students can prepare their theses in the fields of European legal history or modern history. Two members of the senior staff (Karl Härter, Miloš Vec) support their work and participate in the curriculum by lecturing and holding seminars. They are members of the Department for Social and Historical Sciences and the Faculty of Law at the University of Darmstadt and the University of Frankfurt. Doctoral students can also graduate under the supervision of Thomas Duve at the Johann-Wolfgang-Goethe University of Frankfurt am Main. Great importance is attached to the IMPRS for Comparative Legal History which has been active since the winter semester 2002/2003. The IMPRS for Comparative Legal History is jointly sponsored by the MPI Frankfurt and by the Department of Legal History of the Faculty of Law at the University of Frankfurt/Main, and has developed into a major vehicle for the support of young academics. The work of the IMPRS for Comparative Legal History consists of weekly seminars, in which the members of the school present their projects in turn, or other presentations on themes of general interest are held, as well as in regular academic conferences. IMPRS REMEP students are most welcome to participate in these seminars and conferences.

\section{Halle/Saale}

The Seminar for Social and Cultural Anthropology (SSCA) at the Martin-Luther-University Halle-Wittenberg (MLU) focuses on contemporary developments related to new forms of globalisation and localisation and hence on the emergence and the contestations of a world society with transnational networks and all-embracing mediatisations. These developments raise new questions about old anthropological issues like universalism and difference. The challenge of revealing the blind-spots of Euro-American cultures by learning about other cultures is part of this contemporary process. Attempts at de-escalating conflicts and catastrophes inside and outside Euro-America also need to (or should need to) negotiate between, on the one hand, interventions (necessarily based on universal standards) in intolerable developments and, on the other hand, the potential hegemony coinciding with these interventions. From a methodological point of view, social anthropology, as practiced at the SSCA, belongs to the category of qualitative and interpretive social and cultural sciences. Within this group of disciplines it sets itself apart via its central theoretical question: How is it possible to translate inaccessible alienity into intelligible alterity (from alius to alter) without losing the difference in the process of doing so? The skilled processing of this paradox is the business of social anthropology. The three sections of the Seminar for Social and Cultural Anthropology at the MLU reflect this agenda in their further specifications: "Law, Organisation, Science and Technology" with a regional focus on Africa; "Tourism/ Diaspora/ Anthropology of the Night/ Modi of Transmaritime Connectivity / Port Cities / Small Islands" with a regional focus on South Asia (especially Orissa) and the Indian Ocean (especially Mauritius); and the "Anthropology of Europe and the Mediterranean (EuroMed)".

The MPI for Social Anthropology (Halle/S.) concentrates on the comparative analysis of contemporary social organization and change with a view to anthropological theory building. The MPI for Social Anthropology is organized in two departments - Department I 'Integration and Conflict' (headed by Günther Schlee) and Department II (headed by Chris Hann) -, the "Siberian Studies Centre" (Schlee and Hann), and the Project Group 'Legal Pluralism' (headed by Keebet von Benda-Beckmann and Franz von Benda-Beckmann). In a joint set of interrelated questions, the research units analyse issues of integration and conflict, social identification, property relations, religion, forms of social security, economy and ritual, political economy of cultural heritage, historical anthropology and legal pluralism. Within this framework researchers address basic social problems and theory building in social sciences. Extensive fieldwork is an essential part of 
all research projects. Focal research areas are spread throughout Europe, Asia, and Africa. The MPI for Social Anthropology is embedded in an international research network. Since its foundation in 1999 it has developed alongside the neighboring SSCA of the Martin Luther University Halle-Wittenberg (founded in 2002) to become the largest centre of anthropological competence and research in Europe. For many years now, the Martin Luther University HalleWittenberg and the Max Planck Institute for Social Anthropology have collaborated in a series of research projects on the basis of a quite broad cooperation agreement. Research projects addressing issues related to the IMPRS REMEP research design and training include those dealing with conflict analysis in settings where a background of segmentary social organization and clan or tribal structures interacts with the state. Furthermore, retaliation -particularly in processes of conflict regulation - within and beyond state normative systems in connection with transnationalism, religion and migration are being addressed in the current research programmes of the Project Group 'Legal Pluralism'.

Doctoral students at the MPI for Social Anthropology are being graduated Dr. phil. at the SSCA of the Martin-Luther-University HalleWittenberg by the Faculty of Philosophy I and at the Faculty of Law and Economics (due to the cooperation with the Project Group 'Legal Pluralism'). Both directors and both heads of the Project Group hold honorary professorships at the Martin-Luther-University Halle-Wittenberg as well as at the University of Leipzig. The directors/heads and the (senior) staff of the MPI participate in the curriculum of the Seminar for Social and Cultural Anthropology and of the Faculty of Law and Economics. The directors and heads of the project group participate in exams at the graduate and post-graduate level while the senior staff is regularly engaged in lecturing at the SSCA and, occasionally, at the Institute for Anthropology in Leipzig. Since 2005 Richard Rottenburg (chair holder at the SSCA and university partner in the IMPRS REMEP) holds the position of a Max Planck Fellow at the MPI, heading the Max Planck Fellow Group "Law, Organisation, Science and Technology (LOST)”. In addition, both the MPI for Social Anthropology and the MartinLuther-University Halle-Wittenberg closely cooperate in the Graduate School 'Society and Culture in Motion' and the 'Centre for Inter- disciplinary Area Studies - Middle East, Africa, Asia (ZIRS)'. This includes the participation of the directors and senior staff (Bert Turner) in lecturing. Since 2010 both institutions jointly organize a post-graduate course in social anthropology open to all PhD candidates.

Besides graduation at the adjacent Universities - which includes also the University of Leipzig - supervision and graduation of "external" doctoral students in cooperation with other German universities and joint doctoral procedures in collaboration with foreign universities are conducted (i.e. Erasmus University Rotterdam, University of Wageningen, Université de Provence, Aix-en-Provence). Moreover, the MPI and the SSCA are engaged in cooperation in the Priority Programme 1448 "Adaptation and Creativity in Africa - Significations and Technologies in the Production of Order and Disorder" together with the University of Leipzig. The Priority Programme is funded by the German Research Foundation. Furthermore the two institutes in Halle have recently submitted a further research programme to the German Federal Ministry of Education and Research for funding. This programme is entitled "Human Security in African Contexts". The internationality of doctoral students connected with the expectation that students spend a full year in the field requires special support and training. Training in local languages and supervision of the students in the field facilitated by the above mentioned regional clusters supports discussion of individual research and the sharpening of comparative dimensions. Language acquisition of rarely spoken local languages has been financially supported by special funding of the Max Planck Förderstiftung and private sponsorship.

\section{Heidelberg}

The MPI for Comparative Public Law and International Law (Heidelberg) combines fundamental research in public international law with a comparative approach to constitutional and administrative law. As in the case of the MPI Frankfurt, the MPI Heidelberg is not organized in departments but rather aims at a scholarly elaboration of legal questions, treating their international, European and national components as a functional unity. Research at the MPI Heidelberg comprehends the foundations and the exercise of public functions of states and transnational entities in all their manifestations, based on the premise that pub- 
lic international law and domestic public law are increasingly intertwined. This inte-grated approach allows for the analysis and understanding of the preconditions and structures of the exercise of public authority in the 21 st century. The goal is the conceptual and theoretical permeation of positive law as well as the promotion of the formulation and development of positive law. Research concentrates on the theoretical foundations of transnational law and legal theory, the law of the European Union, constitutional developments in Islamic states, Africa, and Asia. In the field of public international law, research focuses on the law of international organizations, in particular the United Nations, international economic law, international environmental law, the international protection of human rights, and the law of war. Current projects of special interest for the topic of the IMPRS scientific agenda and training address the fundamental question of legitimacy in international law, legal questions of transnational multilevel systems as well as the systematization of theories on international law.

Doctoral students who are affiliated with the MPI Heidelberg receive the graduation title of Dr. iur. from the Faculty of Law of the Ruprecht-Karls University of Heidelberg or the Faculty of Law of the University of Hamburg. The Directors of the MPI Heidelberg (Armin von Bogdandy and Rüdiger Wolfrum) hold chairs at the University of Heidelberg. Additionally, Rüdiger Wolfrum holds a chair at the University of Hamburg. Both Directors and senior staff participate in the curriculum of the Faculty of Law of the University of Heidelberg. In addition, the MPI Heidelberg is closely integrated into a dense network of national and international cooperative arrangements which are, in part, institutionally anchored. Regarding the latter, one example is the Minerva Centre for Human Rights of the University of Tel Aviv and Hebrew University in Jerusalem. Rüdiger Wolfrum is Managing Director of the Minerva Foundation and Armin von Bogdandy a Member of the Board. In addition, Wolfrum has contributed over the years to the curriculum of the Rhodes Academy for Ocean Law and Policy, which is sponsored by American, Dutch, Icelandic, and Greek institutions. He also belongs to the International Max Planck Research School on Maritime Affairs in Hamburg. Besides this, Wolfrum contributes to an international project of the Harvard Law School aimed at codifying the customary law rules of air and missile warfare. Finally, mention must be made to the establishment and realization of an LL.M. program on international economic law together with the University of Santiago de Chile and the Faculty of Law of the University of Heidelberg. This program is supervised by a senior staff member and one of the Directors (Rainer Grote and Rüdiger Wolfrum).

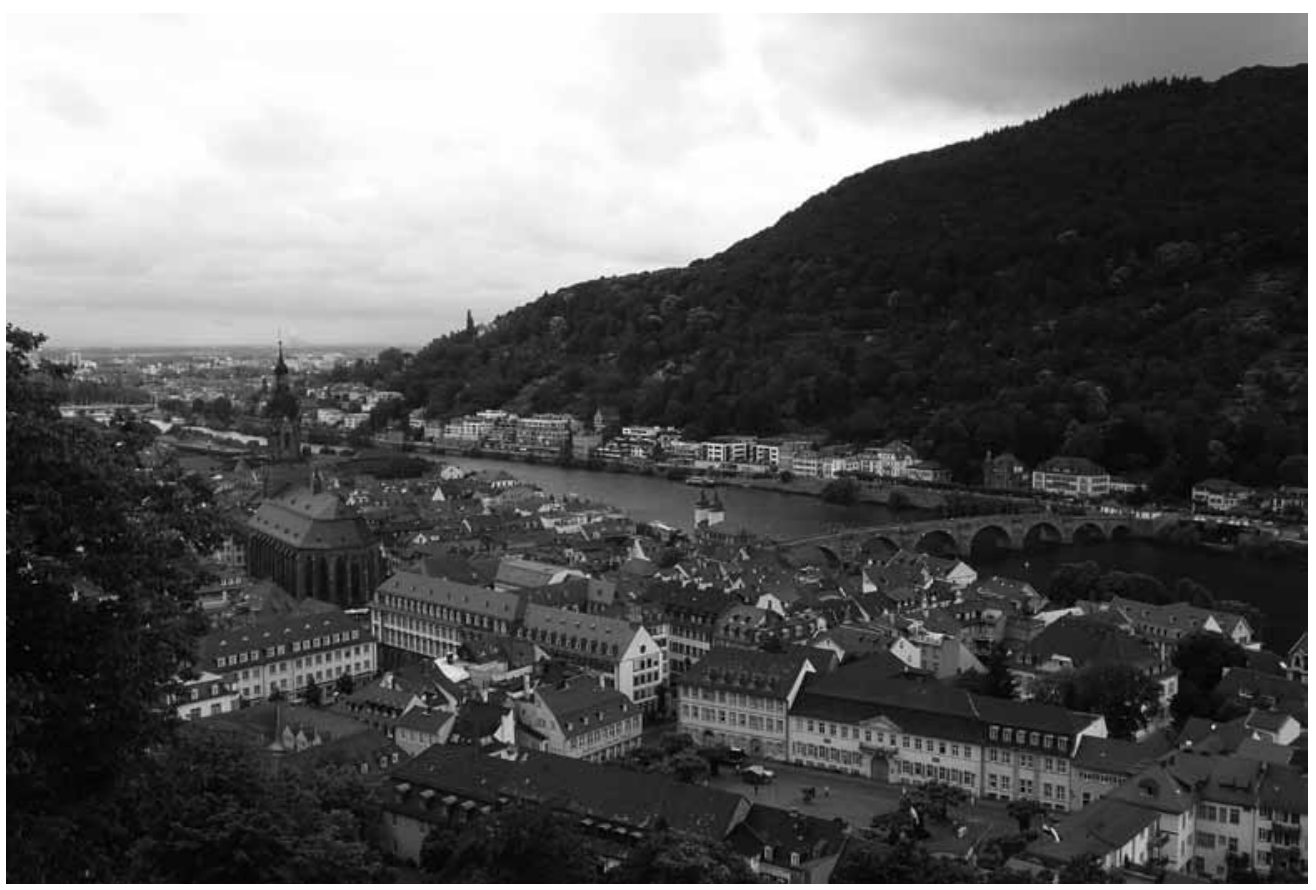




\section{International Co-operations}

The IMPRS REMEP has established international partnerships and collaborations with other universities and research institutions.

The IMPRS REMEP and the Bern Graduate School of Criminal Justice (BGCJ), a graduate school at the Faculty of Law of the University of Bern, Switzerland, started their collaboration in the fall of 2009. Both partners jointly organize tutorials and soft skills training for their doctoral students and support the scientific exchange between both students and senior researchers across the fields of international and comparative criminal law, theory and philosophy of criminal law, criminology, and psychology of law. The IMPRS REMEP doctoral students may attend and participate in the scientific program of the BGCJ offered in Bern and vice versa. REMEP and BGCJ students may choose to conduct parts of their research at the partner institute for up to one academic year. During this exchange period the students are fully integrated into the scientific and social life of the partner institute and are also supervised by a professor of the host institute.

Since 2009, Hofstra School of Law (NY, USA)is another international partner of the IMPRS REMEP. The core element of this partnership is the Summer Law Program, which takes place at the
Max Planck Institute for Foreign and International Criminal Law in Freiburg during the first two weeks in August every summer. Faculty members from the Hofstra School of Law and senior researchers from the MPI as well as invited speakers (co-)teach subjects relevant to REMEP, such as criminology, comparative criminal law, and criminal policy. A student body of up to 25 , composed of students from American law schools and doctoral candidates from the IMPRS REMEP, participate in this American Bar Association-accredited program annually. Moreover, under the International Visiting Researcher Program, doctoral students from the IMPRS REMEP may conduct research for periods of up to three months at Hofstra School of Law on Long Island, NY.

In mid 2011, the IMPRS REMEP and the Centro Studi "Federico Stella" sulla Giustizia penale e la Politica criminale (CSGP) in Milan, Italy, entered into a collaboration to promote joint research, symposia and conferences in the area of criminal law and criminal justice reform with a focus on restorative justice. The first jointly organized workshops are set to take place in 2012. The CSGP is a research centre for criminal law and criminal policy at the Università Cattolica del Sacro Cuore, which is one of the leading academic institutions in Italy. 


\section{B. Program of the IMPRS REMEP}




\section{Thesis Supervision}

The thesis supervision may vary in detail from one REMEP location to another. However, the standard form of supervision is the following: All doctoral students conduct their research at and under the supervision of two professors of one of the REMEP partner institutions. One supervisor may, at times, be an outside expert affiliated with another institution, e.g. the home university of the doctoral student.

In general, each doctoral student has a day-today supervisor, who is usually a senior researcher at the respective partner institution and who provides guidance to the doctoral student on a regular and informal basis. The doctoral student and the first supervisor jointly agree on who should be the second supervisor and the day-to-day supervisor.

The two supervisors and the day-to-day supervisor constitute the so-called Thesis Advisory Committee (TAC) which takes all relevant decisions, such as, e.g., the approval or rejection of the proposal defense, which usually takes place after the drafting of the research design, i.e. after six to eight months after acceptance into the Research School. It is also responsible, where applicable, for the approval of fieldwork plans. The doctoral student shall meet at least every half year with all members of his or her TAC in order to report on and seek guidance and feedback about the research of the past six months and the research planned for the upcoming half year. A written progress report to the TAC is due every year; this report is also to be sent to the Research Schools Office to be included in the student files.

The Max Planck Society for the Advancement of Science does not confer doctoral degrees and titles. Therefore, all REMEP students are doctoral candidates at the partner universities, or home universities in the case of some of the foreign doctoral students. According to the pertinent rules of the partner universities on the conferral of doctoral degrees and titles ("Prüfungs- und Promotionsordnung"), both the first and usually also the second supervisor grade the written thesis and examine (in part) during the oral exams.

According to the student survey, $48 \%$ of the responses were very positive in regards to the academic supervision by the respective first supervisor (15\% / 5 responses excellent, $18 \%$ / 6 responses very good, $15 \%$ good), while $15 \%$ were satisfied ( 5 responses) and one person was unsatisfied (3\%), leaving 27\% (9 responses) with no answer. $49 \%$ of the responses were also positive in regards to the thesis supervision by the second supervisor, leaving two persons unsatisfied and 15 providing no answer. 51\% of the responses were also very positive in regards to the academic guidance they received from other faculty members $(21 \% / 7$ responses excellent, $18 \%$ / 6 responses very good, $12 \%$ good), another $12 \%$ were satisfied (4 responses), while 1 person was unsatisfied, leaving 33\% with no answer (11 responses). 


\section{Curriculum \& Table of Events 2008-2011}

\section{Selected IMPRS REMEP Conferences, Workshops \& Seminars}

\begin{tabular}{|c|c|c|}
\hline Timing & Title & Venue \\
\hline 26 - 29 0ct. 2011 & Conference on Retaliation & Freiburg \\
\hline 29 Sept. 2011 & $\begin{array}{l}\text { Information on the Alexander v. Humboldt Foundation Programs } \\
\text { for PostDoc Fellowships }\end{array}$ & Freiburg \\
\hline 1 - 13 Aug. 2011 & $\begin{array}{l}\text { IMPRS REMEP \& Hofstra University School of Law } \\
\text { Summer Law Program on Policing Youth and Immigration and } \\
\text { Crime }\end{array}$ & Freiburg \\
\hline 13 - 15 July 2011 & Introductory Workshop on Social Anthropology & Halle \\
\hline 29 June - 1 July 2011 & Introductory Workshop on Criminal Law and Criminology & Freiburg \\
\hline 27/28 June 2011 & Soft Skills Workshop on Presentation Skills & Freiburg \\
\hline 1 - 4 June 2011 & Introductory Workshop on Legal History & Frankfurt \\
\hline 30 May - 1 June 2011 & Introductory Workshop on International Law & Heidelberg \\
\hline 28 - 31 March 2011 & Bern Graduate School of Criminal Justice - REMEP Retreat & $\begin{array}{l}\text { Berner Oberland/ } \\
\text { Switzerland }\end{array}$ \\
\hline 2 - 5 March 2011 & Bern Graduate School of Criminal Justice - REMEP Retreat & $\begin{array}{l}\text { Berner Oberland/ } \\
\text { Switzerland }\end{array}$ \\
\hline 18 - 25 Feb. 2011 & IMPRS REMEP Winter University 2011 & Halle \\
\hline Fall Term 2010/2011 & $\begin{array}{l}\text { REMEP Doctoral Students Lecture Series on Violence and } \\
\text { Order }\end{array}$ & Freiburg \\
\hline 13 Dec. 2010 & $\begin{array}{l}\text { Workshop on "Regime Change, State Crime and Transitional } \\
\text { Justice" }\end{array}$ & Freiburg \\
\hline 9 Dec. 2010 & Workshop on EU Funding Opportunities & Freiburg \\
\hline 27/28 Nov. 2010 & Soft Skills Workshop on Academic Writing & Freiburg \\
\hline 18 Nov. 2010 & $\begin{array}{l}\text { Short Course on the History of Retaliation, Mediation and } \\
\text { Punishment: Long Term Developments and Historical Models }\end{array}$ & Frankfurt \\
\hline 150 ct. 2010 & $\begin{array}{l}\text { REMEP colloquium on plea-bargaining „Konsens als Regel - } \\
\text { Was gilt in Mauschelhausen? } 1 \text { Jahr Absprachegesetz“ }\end{array}$ & Freiburg \\
\hline 8/9 Sept. 2010 & IMPRS REMEP Workshop on Retaliation & Bad Lauterberg \\
\hline 1 - 13 Aug. 2010 & $\begin{array}{l}\text { IMPRS REMEP \& Hofstra University School of Law } \\
\text { Summer Law Program on Policing Discretion and on Discretion } \\
\text { at Sentencing and Beyond }\end{array}$ & Freiburg \\
\hline 22/23 June 2010 & Peacebuilding Workshop & Freiburg \\
\hline
\end{tabular}




\begin{tabular}{|c|c|c|}
\hline Timing & Title & Venue \\
\hline 1. & 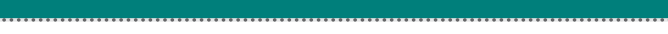 & 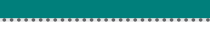 \\
\hline 18/19 Feb. 2010 & $\begin{array}{l}\text { Soft Skills Training on Presentation Skills and Academic } \\
\text { Writing }\end{array}$ & $\begin{array}{l}\text { Husseren-Les- } \\
\text { Châteaux, Alsace/ } \\
\text { France }\end{array}$ \\
\hline 13 - 19 Feb. 2010 & IMPRS REMEP Winter University 2010 & $\begin{array}{l}\text { Husseren-Les- } \\
\text { Châteaux, Alsace/ } \\
\text { France }\end{array}$ \\
\hline 10 Nov. 2009 & Workshop on International Criminal Law & Freiburg \\
\hline 27 July - 8 Aug. 2009 & $\begin{array}{l}\text { IMPRS REMEP \& Hofstra University School of Law } \\
\text { Summer Law Program on Intl. Financial Crimes and Death } \\
\text { Penalty }\end{array}$ & Freiburg \\
\hline 5/6 March 2009 & IMPRS Soft Skills Seminar cont. on Presentation Techniques & Freiburg \\
\hline 12/13 Feb. 2009 & IMPRS Soft Skills Seminar on Presentation Techniques & Freiburg \\
\hline 2 - 7 Feb. 2009 & IMPRS REMEP Winter University 2009 & Freiburg \\
\hline 22 - 25 June 2008 & $\begin{array}{l}\text { Introductory Workshop on Social Anthropology - IMPRS } \\
\text { REMEP Teaching Course }\end{array}$ & Halle \\
\hline 16 - 20 June 2008 & $\begin{array}{l}\text { Introductory Workshop on Criminal Law \& Criminology as it } \\
\text { relates to REMEP }\end{array}$ & Freiburg \\
\hline 19/20 June 2008 & Soft Skills Workshop on Poster Writing & Freiburg \\
\hline 16/17 June 2008 & Soft Skills Workshop on Project Management; Speed Reading & Freiburg \\
\hline 26 - 28 May 2008 & $\begin{array}{l}\text { Introductory Workshop on Public International Law and its } \\
\text { Role for REMEP }\end{array}$ & Heidelbeg \\
\hline 21 - 24 May 2008 & Introductory Workshop on Legal History & Frankfurt \\
\hline 14 - 16 April 2008 & Introductory Seminar & Freiburg \\
\hline 25 Jan. 2008 & Assessment Workshop & Freiburg \\
\hline
\end{tabular}




\begin{tabular}{|c|c|c|}
\hline Timing & Speaker/Affiliation & Topic \\
\hline 11 Aug. 2011 & $\begin{array}{l}\text { Frank Stratz, Police Officer, Police Department } \\
\text { Freiburg }\end{array}$ & Street Work \& Crime Prevention \\
\hline 9 Aug. 2011 & $\begin{array}{l}\text { Cornelia Helfferich, Professor at the Protestant } \\
\text { University of Applied Sciences, Freiburg }\end{array}$ & $\begin{array}{l}\text { Immigration and Crime: Victims of } \\
\text { Human Trafficking }\end{array}$ \\
\hline 5 Aug. 2011 & Marion Sieber, Juvenile Court Judge, Freiburg & $\begin{array}{l}\text { Policing Youth: Discussion on German vs } \\
\text { American Juvenile Sentencing }\end{array}$ \\
\hline 30 June 2011 & $\begin{array}{l}\text { Anna Alvazzi del Frate, Senior Researcher, Small } \\
\text { Arms Survey (Geneva) }\end{array}$ & $\begin{array}{l}\text { Armed Violence in Urban Settings - } \\
\text { Cities as Opportunities for Violence and } \\
\text { Facilitators for Change }\end{array}$ \\
\hline 20 June 2011 & $\begin{array}{l}\text { Reinhart Kößler, Arnold Bergstraesser Institute, } \\
\text { Freiburg }\end{array}$ & $\begin{array}{l}\text { Reconciliation and Transition in Post- } \\
\text { Colonial Namibia }\end{array}$ \\
\hline 3 June 2011 & $\begin{array}{l}\text { Daniel Saxon, Leverhulme Visiting Professor, } \\
\text { Lauterpacht Centre for International Law, } \\
\text { Cambridge University / Former Senior Prosecutor } \\
\text { ICTY }\end{array}$ & $\begin{array}{l}\text { Conflicting Rights in International } \\
\text { Criminal Trials }\end{array}$ \\
\hline 20 April 2011 & $\begin{array}{l}\text { Joxerramon Bengoetxea, Professor of Law at the } \\
\text { International Institute for the Sociology of Law, } \\
\text { Antigua Universidad, Oñati/Spain }\end{array}$ & $\begin{array}{l}\text { Could Judges Make Mistakes? Legal } \\
\text { Reasoning and International Criminal } \\
\text { Law in the Garzon Case }\end{array}$ \\
\hline 21 Feb. 2011 & $\begin{array}{l}\text { David Whyte, Professor at the School of Sociolo- } \\
\text { gy and Social Policy, University of Liverpool }\end{array}$ & $\begin{array}{l}\text { The Preconditions of State Terror: } \\
\text { Dismantling The Reasons of State }\end{array}$ \\
\hline 19 Feb. 2011 & $\begin{array}{l}\text { Anne Griffiths, Professor of Law at the School of } \\
\text { Law, University of Edinburgh }\end{array}$ & $\begin{array}{l}\text { Integrating a Perspective on Gender in } \\
\text { Social Science and Law }\end{array}$ \\
\hline 10 Nov. 2010 & $\begin{array}{l}\text { Ferdinand Gillmeister, Criminal Defence Lawyer } \\
\text { with Expertise in White Collar Crime Defence, } \\
\text { Freiburg }\end{array}$ & $\begin{array}{l}\text { Kronzeugenregelung und Absprachen in } \\
\text { Strafverfahren - Ein Jahr Erfahrung aus } \\
\text { Sicht der Strafverteidigung ["A defence } \\
\text { lawyer's perspective on the new law on } \\
\text { crown witnesses and plea bargaining"] }\end{array}$ \\
\hline 260 ct. 2010 & $\begin{array}{l}\text { Klaus Hoffmann, Prosecutor at the District } \\
\text { Attorney's Office Freiburg, Former Prosecutor at } \\
\text { the ICTY }\end{array}$ & $\begin{array}{l}\text { German and International Prosecutions - } \\
\text { A Comparison }\end{array}$ \\
\hline 12 July 2010 & $\begin{array}{l}\text { Gunther Teubner, Professor of Private Law and } \\
\text { Legal Sociology, Goethe University / Frankfurt } \\
\text { a.M }\end{array}$ & $\begin{array}{l}\text { Constitutionalism beyond the State: } \\
\text { Social Movements and the Codes of } \\
\text { Transnational Corporations }\end{array}$ \\
\hline $\begin{array}{l}22 / 23 \text { June } \\
2010\end{array}$ & $\begin{array}{l}\text { Chris van der Borgh, Assistant Professor at the } \\
\text { Centre for Conflict Studies, Utrecht University }\end{array}$ & $\begin{array}{l}\text { Practice of International Interventions } \\
\text { in El Salvador - Problems of Building a } \\
\text { Liberal Peace }\end{array}$ \\
\hline 15 May 2010 & $\begin{array}{l}\text { Arata Takeda, Researcher at Deutsches Seminar } \\
\text { of Tuebingen University }\end{array}$ & $\begin{array}{l}\text { Skizze einer „anderen“ Kulturgeschichte } \\
\text { des Selbstmordattentats. Ein ungewöhn- } \\
\text { licher Spaziergang durch die abendlän- } \\
\text { dische Kultur }\end{array}$ \\
\hline 16 March 2010 & $\begin{array}{l}\text { Jeffrey Fagan, Professor of Law \& Public Health, } \\
\text { Director }\end{array}$ & $\begin{array}{l}\text { Surveillance and Suspicion: Crime } \\
\text { Control and Pretextual Intelligence }\end{array}$ \\
\hline 14 Feb. 2010 & $\begin{array}{l}\text { Ineta Ziemele, Judge of the European Court of } \\
\text { Human Rights }\end{array}$ & $\begin{array}{l}\text { Key Note Speech: International Human } \\
\text { Rights Justice and State Building in } \\
\text { Post-Conflict Societies. Dilemma } \\
\text { Encountered by the Strasbourg Court }\end{array}$ \\
\hline
\end{tabular}




\begin{tabular}{|c|c|c|}
\hline Timing & Speaker/Affiliation & Topic \\
\hline 10 Nov. 2009 & $\begin{array}{l}\text { Koffi Afande, Legal Officer, Head of Appeals } \\
\text { Chamber Support Unit / ICTR }\end{array}$ & $\begin{array}{l}\text { Referral of Cases to National } \\
\text { Jurisdictions }\end{array}$ \\
\hline 5 Aug. 2009 & $\begin{array}{l}\text { Wolfgang Hetzer, Advisor to the Director General, } \\
\text { European Anti-Fraud Office (OLAF) }\end{array}$ & Legalising Corruption? \\
\hline 13 July 2009 & Serge Brammertz, Prosecutor of the ICTY & $\begin{array}{l}\text { Specific Challenges of International } \\
\text { Investigations }\end{array}$ \\
\hline 25 May 2009 & $\begin{array}{l}\text { Michael Tonry, Marvin J. Sonosky Professor of } \\
\text { Law and Public Policy, School of Law at } \\
\text { University of Minnesota }\end{array}$ & $\begin{array}{l}\text { Penal Policy Studies } \\
\text { - A Natural History }\end{array}$ \\
\hline 4 Feb. 2009 & $\begin{array}{l}\text { Trutz v. Trotha, Professor of Sociology, University } \\
\text { of Siegen }\end{array}$ & About Cruelty \\
\hline 3 Feb. 2009 & $\begin{array}{l}\text { Olivia Swaak-Goldmann, ICC-OTP - } \\
\text { Jurisdiction,Complementarity, Cooperation } \\
\text { Division }\end{array}$ & $\begin{array}{l}\text { International Criminal Prosecutions: } \\
\text { Their Role and Challenges in } \\
\text { Establishing Social Order }\end{array}$ \\
\hline 2 Feb. 2009 & $\begin{array}{l}\text { Albin Eser, Professor of law em., University } \\
\text { of Freiburg; director em. MPI for Foreign and } \\
\text { International Criminal Law \& Eugene 0'Sullivan, } \\
\text { International Defence Attorney }\end{array}$ & $\begin{array}{l}\text { Common vs. Civil Law: which legal } \\
\text { system is better suited to address the } \\
\text { challenges posed by international } \\
\text { criminal justice? }\end{array}$ \\
\hline 22 Jan. 2009 & $\begin{array}{l}\text { Margit Oswald, Professor of Psychology, Insti- } \\
\text { tute for Social Psychology, University of Berne }\end{array}$ & $\begin{array}{l}\text { Layperson's Judgment on Punishment } \\
\text { of Crime }\end{array}$ \\
\hline 27 Nov. 2008 & $\begin{array}{l}\text { Ferdinand Gillmeister, Criminal Defence Lawyer } \\
\text { with Expertise in White Collar Crime Defence }\end{array}$ & Plea Bargaining in White Collar Crimes \\
\hline 27 0ct. 2008 & $\begin{array}{l}\text { Martti Koskenniemi, Director of the Eric Castrén } \\
\text { Institute of International Law and Human Rights, } \\
\text { University of Helsinki }\end{array}$ & Between Impunity and Show Trials \\
\hline
\end{tabular}

The integrated multidisciplinary curricular activities of the IMPRS REMEP are designed for a three year period. The teaching language is English. Participation in most tutorials and workshops is mandatory. Purposely, no credit system has been put in place. The group of doctoral students is relatively small and has a diverse academic background. Therefore, it does not seem to make sense to set up a credit system but to ensure on an individual basis that the respective student receives the necessary training in order to successfully conduct his or her research within his or her discipline, while being acquainted with the pertinent methods and theories also of the other disciplines involved in and focusing on retaliation, mediation, and punishment. In this regard, the TAC and the other faculty members provide necessary guidance during one-on-one meetings, the introductory courses, the annual Winter Uni- versity and the thematic workshops as well as on an ad hoc basis.

Key literature from each discipline comprising four volumes, classified in both mandatory and recommended literature, is made available to the student body via the IMPRS REMEP intranet. Moreover, for course or workshop, the faculty requests the doctoral students to read specific literature which is also made available on the intranet.

Introductory Workshops: At the beginning of the first year, all incoming doctoral students are required to participate in so-called Introductory Workshops, consecutively taking place at each of the IMPRS locations. The doctoral students are acquainted with the relevant empirical methods and significant theories of each discipline involved within the context of REMEP. 
Each workshop lasts three days and, thus, allows sufficient time for both the faculty and the student body to get to know all participants as well as other researchers at the Max Planck Institutes and universities. The program addresses the following topics:

(1) History of the state and the emergence of modern punishment (Frankfurt/Main): The course covers the history of criminal law, criminal justice, modern punishment and the modern state in Europe from the late middle ages to modern times, including the development of state based forms of institutionalised, formalised, punitive control and the establishment of a monopoly of power.

(2) Criminal Justice History (Frankfurt/Main): The course covers theory, models, methods and results of research in the field of Criminal Justice History, including issues like the "enforcement/implementation of norms", "participation of the social community in criminal justice, punitive control and coercion", the "negotiation/mediation of norms, conflicts and social/punitive control" and the "complex relationships between norm and practice" as well as models like "utilization/instrumentalization of criminal justice" (Justiznutzung) and "infrajustice".

(3) Retaliation and mediation in tribal societies (Halle/Saale): The course focuses on REMEP as conflictive and/or integrative socio-legal strategies of exclusion and inclusion highlighting processes of conflict management ranging from the exercise of violence to reconciliation between formally equal social, political or organisational formations on various institutional levels from kinship structures via state organization to the international level.

(4) Conceptualising REMEP in legal anthropology (Halle/Saale): This course covers normative ordering and retaliatory practices in plural legal configurations; global justice; the transnationalization of legal standards and the idea of retaliation; the anthropology of retaliation (from an evolutionary model of blood feud to the conceptualisation of the social working of the idea of reciprocity in normative ordering and conflict settlement, including colonial-postcolonial settings), cultural defence.

(5) International justice (Heidelberg): The course covers concepts of international justice as embodied in international law, including issues like the enforcement and implementation of international law norms, negotiation and mediation in international law, the international law of retaliation, the element of reciprocity in international law and its limits.

(6) Weak/failed states, the concepts of war and crime and the role of the Security Council (Heidelberg): The course covers issues of inclusion of non-state actors (International Organisations and individuals) in retaliation, mediation and punishment in international law and overlapping concepts of war and crime in international law e.g. in the fight against terrorism.

(7) Theories of crime and punishment (Freiburg i.Br.): The course covers the development of theories concerning criminal sanctions and punishment, including sentencing and the relationship between models of man, theories of crime and punishment theory. The course shall convey basic knowledge about the goals that can be pursued with criminal punishment as well as information on contemporary systems of criminal sanctions. The introduction into systems of criminal sanctions is presented in a comparative perspective and includes criminological findings about the actual effects of criminal punishment and sentencing.

(8) Retaliation and mediation within the framework of criminal law (Freiburg i.Br.): The course covers the escalation potential of retaliation, the reintroduction of mediation and reconciliation as a result of rediscovering the victim and developing crime victim policies, restorative justice as an alternative to maintaining order and peace through retaliatory punishment; prospects and limits of mediation and reconciliation in individualized and heterogeneous societies.

Winter University: At the beginning of each year, all doctoral students and the faculty convene during the so-called Winter University. The Winter University lasts one week and is organized by the student body with the help and guidance of the Student Office. The Winter University is currently designed on a three tier model: incoming doctoral students are required to present their research plan (30 minutes) and to answer questions and engage in discussion with the faculty and student body (30 minutes). Second-year-students are expected to share their research results (30 minutes presentation), which will then be discussed again in the 
plenary (30 minutes). Thus, the Winter University offers the students a platform to compare their research results on a cross-disciplinary basis with the results of their colleagues while being made aware of the connections and discontinuities between social and legal developments. The relative quality of one's own concepts, methods, and theoretical background is also tested. Students in their final year act as chair persons and deliver paper presentations in thematic workshops. The aim is to contribute to a theory of the role of retaliation, mediation, and punishment for peace and social order by categorizing varying forms of interaction related to REMEP between different social agents, and, on this basis, by determining and classifying on a comparative basis REMEP and social order in theoretical models. Purposely, the teaching component, which used to be more prominent during the first two years of the IMPRS REMEP has been reduced to now only a few teaching modules of faculty members as well as internationally renowned guest researchers because it was felt that the doctoral students benefit most from discussions and directions from the faculty in this arrangement.

The scientific part of the Winter University is followed by a two-day soft skills seminar, e.g. on project management \& trouble shooting, rhetoric \& presenting skills or academic writing conducted by a professional soft skills trainer.

The student body published the Summary of Proceedings of the Winter University 2009 in Research in Brief, an in-house publication of the Max Planck Institute for Foreign and International Criminal Law. The papers presented during the Winter University 2011 were submitted for publication on an individual basis.
The Winter University is regularly organized as a retreat in a relatively secluded area, allowing for an intensive exchange of ideas and a strengthening of the team spirit of the group. It is complemented by a social program including hikes, wine tasting, visits to museums and nearby towns etc. It is worth mentioning that according to the survey, $82 \%$ of the doctoral students cherish the REMEP team spirit and claim that they feel very well integrated into the Research School. 64\% (21 responses) feel that there is a strong mutual support among the student body, $12 \%$ (4 responses) judge the mutual support as good, while 2 persons $(6 \%)$ feel that the support is unsatisfactory, leaving $6(18 \%)$ with no answers.

Fieldwork: Usually, after having successfully defended their research proposal, doctoral students at the MPI for Social Anthropology spend up to one year abroad doing their fieldwork. Doctoral students at the MPI for Foreign and International Criminal Law might also do expert interviews, surveys or observations, however, usually during a significantly shorter period of time.

The Research School is considering reducing the number of mandatory curricular activities. The feedback of the student body showed that $75 \%$ (24 responses) do not ask for an increase in mandatory activities but would prefer more optional curricular activities. However, 50\% (16 responses) consider the work load as adequate, $19 \%$ as inadequate (6 responses), and $31 \%$ provided no answer to this question (10 responses).

\section{REMEP Conferences, Workshops, Guest Lecture Series}

Thematic workshops / short courses (ranging from 1 to 3 days) are taught by the REMEP faculty and senior researchers of the partner institutions throughout the academic year. All interested REMEP students are welcome to attend.

From 26 - 29 October 2011, the REMEP faculty organized an international conference "On
Retaliation" (cf. program in F. Appendices, 4., pp. 98) at the Max Planck Institute for Foreign and International Criminal Law in Freiburg and thus followed up on previous conferences and joint publication projects on retaliation, mediation, and punishment. Even prior to the establishment of the Research School, the IMPRS REMEP faculty members had collaborated in organizing a series of workshops. Two focused 
on conflict resolution in the Middle East, taking place in Istanbul in 2003 and 2004. They resulted in a joint publication: Albrecht, Simon, Rezaei, Rohne, Kiza (ed.), Conflicts and Conflict Resolution in Middle Eastern Societies - Between Tradition and Modernity, Duncker \& Humblot, 2006, 658 pp. A workshop on retaliation and regulation without central power ("Vergeltung und Regulation ohne Zentralgewalt") followed in Stuttgart in 2004 and led to another joint publication: Günther Schlee et al., Vergeltung, Campus, 2008, 188 pp.. In October 2011, the conference "On Retaliation" brought together ten invited guest speakers from Germany and abroad, internationally renowned experts in the fields of criminology, econometrics, history, management, psychology, and social anthropology. In addition to the external experts, five REMEP faculty members as well as five doctoral students presented papers. The sessions were mainly chaired by the student body. The conference papers are currently being edited and will most likely be published by Berghahn Books. Similar international conferences with a focus on mediation and punishment are to follow in 2013. The student survey made clear that the doctoral students appreciate and are very supportive of such conferences: $62 \%$ judged the academic and scientific quality of this conference very favorably (19\% excellent (6 responses), 29\% (9 responses) very good, $16 \%$ good (5 responses), while one person judged it as unsatisfactory $(3 \%)$ and $34 \%$ provided no answer (11 responses).

A key aspect of the Research School is the REMEP Guest Lecture Series, which has featured up until now about thirty internationally renowned experts, academics as well as practitioners, who give talks, present papers and/ or offer a workshop on questions regarding the role of retaliation, mediation and punishment for peace and social order. The doctoral students are encouraged to invite experts in whose work they take a special interest and with whom they wish to establish closer working relationships.

Since 2011, the Bern Graduate School of Criminal Justice (BGCJ) and the IMPRS REMEP jointly carry out a tutorial each winter in the Swiss Alps. Doctoral students of both schools present their research projects and findings and discuss them with faculty members of the BGCJ and the IMPRS REMEP.
Since 2009 the IMPRS REMEP and Hofstra School of Law jointly organize a Summer Law Program during the first two weeks of August at the MPI for Foreign and International Criminal Law in Freiburg. The senior researchers of the MPI as well as invited speakers (co-) teach on varying topics with relevance for REMEP on criminology, comparative criminal law, and policy during two weeks each summer (the subjects vary but always have a comparative perspective: juvenile justice and immigration \& crime [2011], discretion at sentencing and policing discretion [2010], international financial crimes and mass incarceration \& death penalty [2009]). A student body of up to twenty-five US American law students and doctoral students of the IMPRRS REMEP participate in this American Bar Association accredited program.

At each partner Institute and university a whole range of lectures, brown bag seminars and other curricular activities are offered on a regular / weekly basis to which all REMEP students are invited to attend.

Depending on the individual needs of the doctoral student, he or she is advised by his or her TAC to also attend specific seminars and courses at the partner or local university. In specific cases the doctoral student may be required to do so as a prerequisite to be admitted as a doctoral student by the university.

Apart from the scientific curricular activities, the IMPRS REMEP regularly offers to its doctoral students so-called soft skills training, ranging from e.g. project and time management, to presenting skills (rhetoric and poster writing), to academic writing as well as grant application writing, usually within the context of the Winter University. Additional soft skills training units are offered on demand at the various REMEP locations, such as on software tools for publishing and managing bibliographies, speed reading etc. IGA, the International Graduate Academy of Freiburg University, complements these curricular activities by also offering a whole range of soft skills as well as language classes, proof reading and many more services for free to all doctoral students enrolled at the University of Freiburg.

Conferences: The doctoral students are encouraged to participate in national and international conferences relevant to their specific research. Financial support is granted for paper pres- 
entations but at most REMEP locations also for passively attending important conferences in their field of interest. Financial support for submitting papers is granted as well. According to the feedback of the student body, $74 \%$ of the responses judge the financial support for attending (inter-) national conferences as very positive (45\% excellent [ 15 responses], 9\% very good [3 responses], 18\% good [6 responses]) while one person (3\%) was unsatisfied and 8 (24\%) provided no answer.

\section{Activities by REMEP Students}

The IMPRS REMEP has fostered a student body which is diverse, vibrant and pro-active. For example, at the MPI for Foreign and International Criminal Law, doctoral students initiated a lecture series at the University of Freiburg within the context of the so-called "Studium Generale" during the Winter Term 2010/11. They presented their research results and discussed them with a broad audience. Furthermore, the group of advanced doctoral students meets biweekly to discuss their draft chapters inviting discussants. The doctoral students are also encouraged and (financially) supported to organize their own conferences and to publish the presentations made on that occasion. Up until now several such conferences have been organized and several more are planned for 2012 :

Kiyomi v. Frankenberg, REMEP colloquium on plea-bargaining „Konsens als Regel - Was gilt in Mauschelhausen? 1 Jahr Absprachegesetz," 15 October 2010, MPI for Foreign and International Criminal Law. The conference proceedings were published: Kiyomi v. Frankenberg, Konsens als Regel - Was gilt in Mauschelhausen? Ein Jahr Absprache-Gesetz, Monatsschrift für Kriminologie und Strafrechtsreform vol. 94 (2011) issue 3, pp. 228-235.

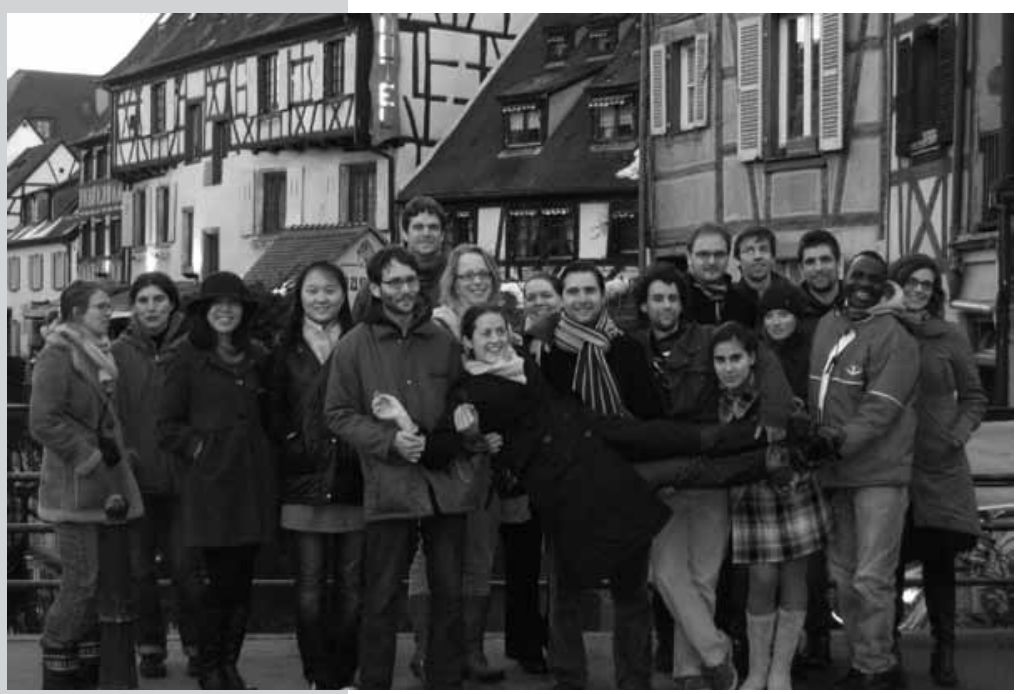

Johanna Mugler, Workshop on "A World of Indicators. Knowledge Technologies of Regulation, Domination, Experimentation and Critique in an Interconnected World," 12-15 October 2011, MPI for Social Anthropology. Currently, Johanna Mugler and her co-conveners are editing the papers to be published by transcript Verlag.

Daniel Bonnard, „Anthropologie historique des pratiques de violence de masse“ (Journées d'étude franco-allemandes de doctorantEs en sciences humaines et sociales) Maison Heinrich Heine, Cité Universitaire Internationale, Paris 25-26 November 2011.

Carolijn Terwindt and Gustavo Rojas Paez, "Whose natural resources? Criminalization of social protest in a globalizing world?" at International Institute for the Sociology of Law in Oñati, Basque Country, 26-27 April 2012.

Csaba Györy is currently preparing a conference on insider trading, a comparison between German and U.S. American regulation and policies which is scheduled to take place at the MPI for Foreign and International Criminal Law in Freiburg in September 2012.

In February 2012, the student body will launch a REMEP - Blog, which will be edited by Kerrin-Sina Arfsten and Peju Solarin, two doctoral students, and feature the research being undertaken by the IMPRS REMEP and their partner institutions. The blog will be content driven. The two editors will publish two to three articles per month and invite other contributions from their fellow doctoral students as well as faculty members and external academics. 


\section{Research Facilities}

Each doctoral student has an individual office space equipped with the latest telecommunication and IT infrastructure at one of the REMEP partner institutions. Specifically, for the purpose of empirical research in the fields of social anthropology and criminology where additional equipment is needed for fieldwork and analysis, students benefit from audio-visual technologies, specific software, and other special tools for qualitative and quantitative data analysis. All students have full access to the partners' extensive libraries, which belong to the largest and most important of their kind in the world, as well as electronic journal and online databanks. Doctoral students receiving a scholarship may ask for financial support, for instance, to purchase literature necessary for their own research (Sachkostenzuschuss) of up to $103 €$ per month. In addition to the modern infrastructure available, doctoral students have benefited from the international composition of the staff at the partner institutions, the multidisciplinary environments, and the numerous foreign researchers from all over the world who come to the institutes and universities to participate actively in the process of research, presenting their work on a regular basis in lectures and workshops.

$82 \%$ of the responses of the student body were positive in regards to the research facilities (office equipment and quality of libraries and online databanks) offered by the partnering institutions (55\% (18 responses) very good, $27 \%$ (9 responses) good while $18 \%$ (6 persons) provided no answer. 


\section{Student Body}

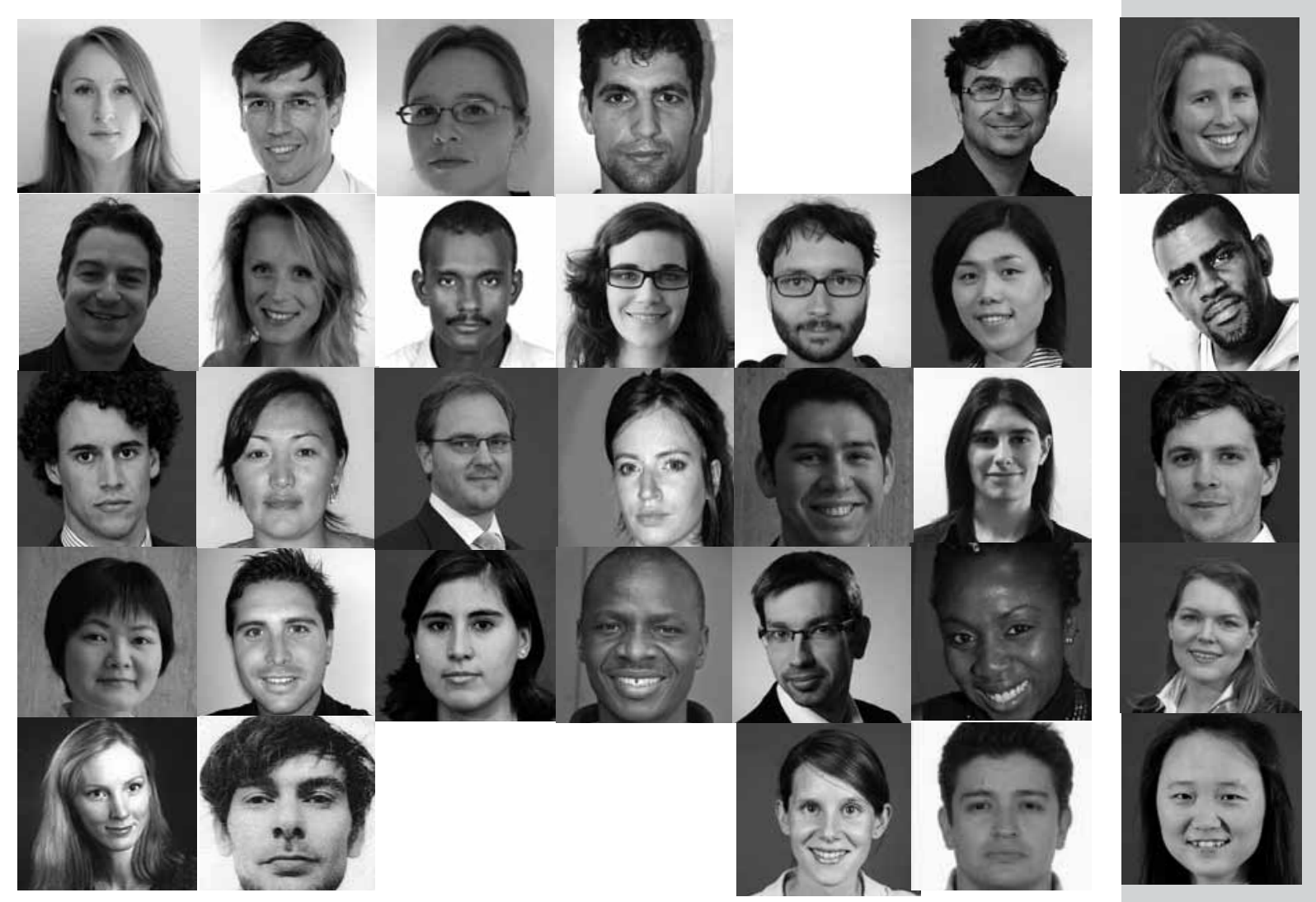




\section{Recruitment Procedure}

In April 2008, the first group of doctoral students was admitted to the IMPRS REMEP at all six institutions. Ever since the acceptance to the Research School has been made on a rolling-entry basis, preferably prior to the spring or fall term.

International calls for applications are launched two months before the closing date for applications on the REMEP and the partners' web pages. The German Academic Exchange Service also promotes the IMPRS REMEP in its paper and online publications. Most importantly, calls for applications are sent through the long-standing international networks of the IMPRS member institutions which make them public on their notice-boards and websites. In addition, calls for applications have been channeled through net works and mailing lists as the Brussels based "kowi" and advertised directly through career centers of word class universities.

More than half of the doctoral students applied to the Research School following a personal recommendation (54\%), a third due to job announcements in the IMPRS REMEP information material (web, flyer, brochure, 16\%) and the webpage of the Max Planck Society $(16 \%)$, and $6 \%$ in response to information on the REMEP partners' web pages. An indicator of the visibility of the Research School is also the number of visits to its web page, which was visited 887 times in August, 826 times in September, 984 times in October, 1010 times in November, and 1019 in December 2011.

The complete application package needs to be sent via email to the Research School's Office, which forwards them to the respec- tive institution at which the doctoral student wishes to conduct his or her research. A local selection committee, staffed with REMEP faculty members, evaluates the applications and invites promising applicants to personal interviews or to participate in an assessment workshop in case several positions are posted. Interviews via video conference are the exception and only done in case the applicants are outside of Europe and the costs of a face-toface interview seem to be out of proportion. Admission to the Research School is on a competitive basis. In case of admission to the spring term, the Executive Committee takes the final decision of admission upon suggestion of the respective institution during its annual meeting. In case of admission to the fall term, the Research School's Office informs and asks the members of the Executive Committee to provide their opinion to the suggested choice via email.

Applicants must have a degree equivalent to the German Diploma/State Exam (e.g. a Master of Science, including a master's thesis) to obtain a doctoral degree from the universities at one of the IMPRS locations. At the universities of Freiburg and Frankfurt it is theoretically possible to begin doctoral studies whilst completing a master's program (LL.M.) of oneand-a-half years. Students who already hold a master's degree can be directly admitted to the doctoral program. Up until now, only doctoral students with a German Diploma/State Exam, an equivalent master's degree, or a submitted master's thesis have been admitted to the IMPRS REMEP. Cf. F. Appendices, pp. 104, 5. Application Requirements. 


\section{Academic Provenance and Nationality of the Student Body}

The International Max Planck Research Schools are supposed to attract at least $50 \%$ of their student body from abroad (IMPRS Concept issued by the Senate of the Max Planck Society in March 1999). At present, 33 doctor-

al students have been admitted to the IMPRS REMEP, out of which 13 (33\%) are of German and 20 (66\%) of non-German citizenship. Among these 33 doctoral students $17(52 \%)$ are female and $16(48 \%)$ male.

Academic provenance of doctoral students (2008-2011):

$\begin{array}{ll}\text { 1. } & \text { Austria: } 1 \\ \text { 2. } & \text { Brazil: } 1 \\ \text { 3. } & \text { Canada: } 1 \\ \text { 4. } & \text { China: } 2 \\ \text { 5. } & \text { Colombia: } 1 \\ \text { 6. } & \text { Costa Rica: } 1 \\ \text { 7. } & \text { Germany: } 12 \\ \text { 8. } & \text { Hungary: } 1 \\ \text { 9. } & \text { Latvia: } 1 \\ \text { 10. } & \text { Mongolia: } 1\end{array}$

11. The Netherlands: 2

12. Peru: 1

13. Spain: 1

14. Sudan: 2

15. Sweden: 1

16. Switzerland: 1

17. Taiwan: 1

18. Uganda: 1

19. USA / Nigeria: 1

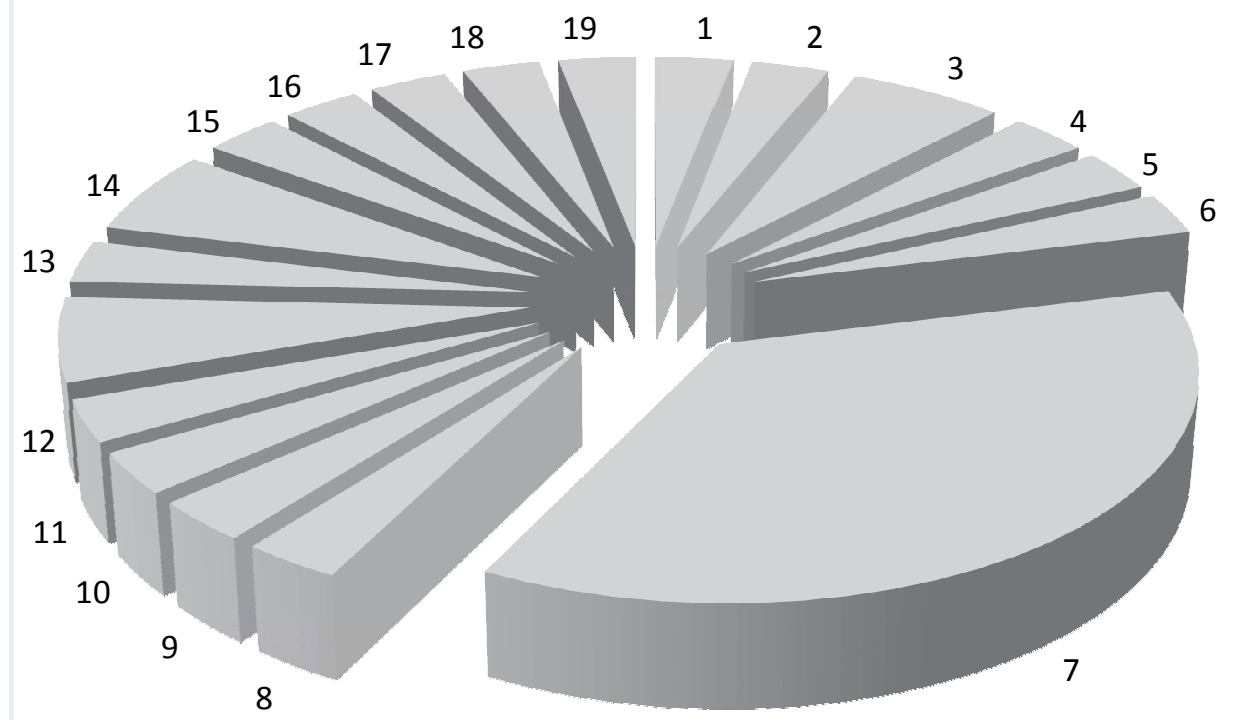




\section{Duration of Doctoral Research Projects \& Results Achieved}

Initially the principal investigators of the IMPRS REMEP had assumed that the students would need two years for writing dissertations in law and three years, including one year of fieldwork, for dissertations in social anthropology (Proposal for the Establishment for the IMPRS REMEP). However, this assumption has proved wrong. Instead the time needed amounts on average to more than 3 years $(37$ months on average for concluded dissertations). There seem to be three main reasons for this. Firstly, more than half of the student body is from abroad; these students have to learn German since the oral exams in law at the universities of Freiburg and Heidelberg are only conducted in German. Secondly, a considerable number of doctoral students with a focus on criminology collect and analyze empirical data, spending several weeks to a few months in the field carrying out interviews and observations. Thirdly, the curriculum of the IMPRS REMEP is quite demanding and time consuming, which no doubt contributes to a slightly prolonged duration.

Three doctoral students already completed their doctoral theses: Juan Canizares Navarro (July 2011, defense at the Faculty of Law of the University of Valencia, Spain, "doctor europeus", excellent cum laude) and Carolijn Terwindt (November 2011, defense at the Faculty of Law of Columbia University, USA) and Lejla Vujinovic (accepted by the Faculty of Law of Bern University, Switzerland, in December 2011). The following doctoral students have already handed in their dissertations and their exams are set to take place in February 2012: Andreas Armborst (Faculty of Philoso- phy of Freiburg University), and David Jensen (Faculty of Law of Freiburg University); the dissertations of Kiyomi von Frankenberg, Mayeul Hiéramente (Faculty of Law of Freiburg University), and Inga Švarca (Faculty of Law, Hamburg University) are currently under review. The dissertations of Meng-Chi Lien, Shakira Bedoya Sánchez and Jennifer SchuetzeReymann are expected to be handed in during the spring term 2012 at the Faculty of Law of Freiburg University. The same is expected for the dissertations of Johanna Mugler, Friederike Stahlmann, and Severin Lenart, which will be handed in at the Faculty of Philosophy 1 at the University Halle-Wittenberg during the spring term 2012.

Up until now, the pertinent rules on the conferral of doctoral degrees and titles ("Priifungs-und Promotionsordnung") at most German law faculties as well as those of other faculties in the humanities and social sciences still require the doctoral students to write a monograph versus a cumulative dissertation. The number of peer reviewed publications in internationally recognized journals of the REMEP student body needs to be seen in this context, thus being in line with the still prevailing scientific tradition in this area of study. However, the Research School strongly encourages and also supports the doctoral students to publish parts of their research results at least once in an internationally recognized journal during their stay at the IMPRS. Specifically for this purpose, academic writing workshops are offered. Moreover, financial support for submitting draft papers is granted. Cf. publication records below (Doctoral Research Projects, pp. 47). 


\section{Doctoral Students}

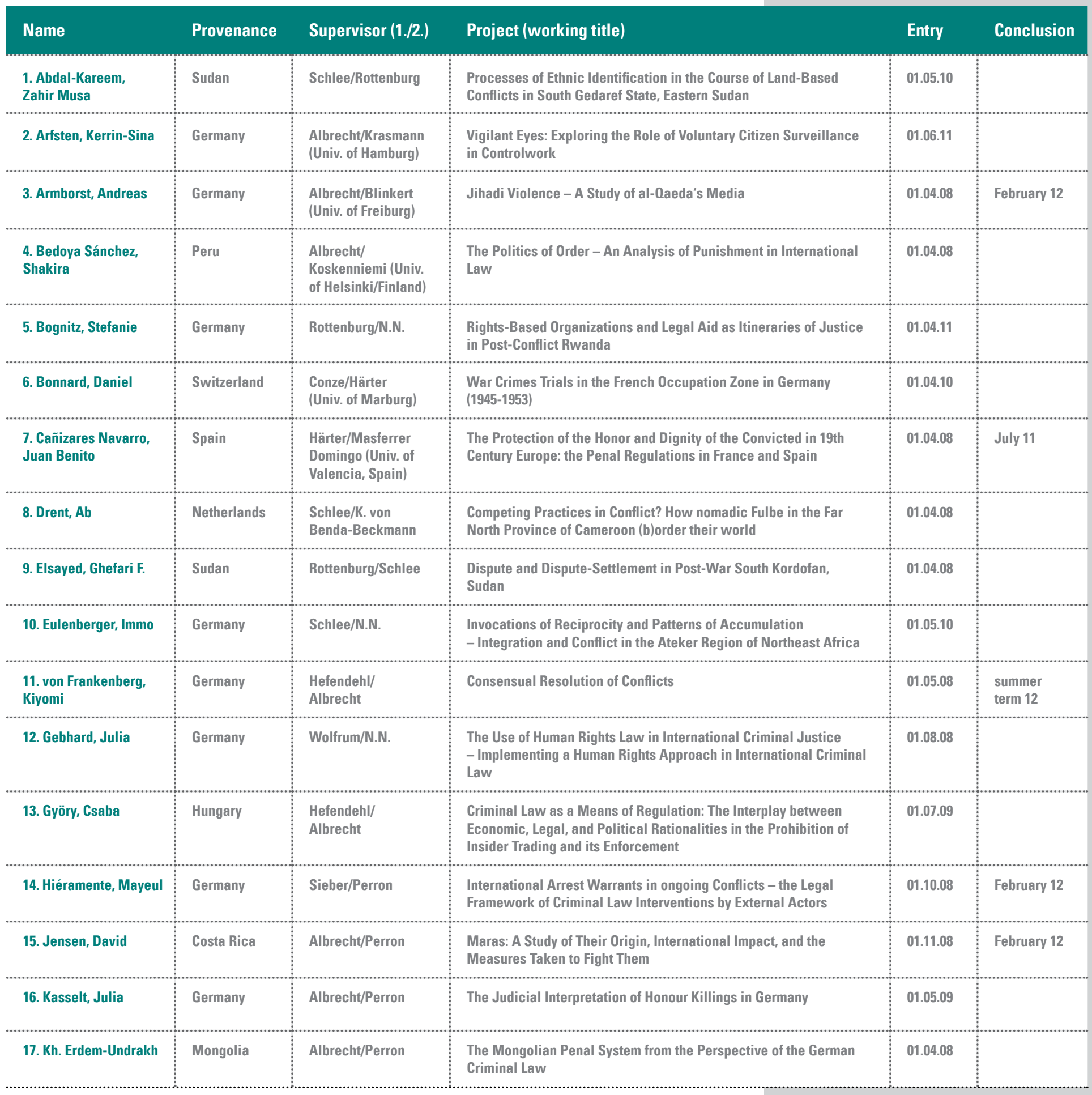




\section{Doctoral Students (cont.)}

\begin{tabular}{|c|c|c|c|c|c|}
\hline Name & Provenance & Supervisor (1./2.) & \multirow[t]{2}{*}{ Project (working title) } & \multirow[t]{2}{*}{ Entry } & \multirow[t]{2}{*}{ Conclusion } \\
\hline & & & & & \\
\hline 18. Lenart, Severin & Austria & $\begin{array}{l}\text { K. von Benda- } \\
\text { Beckmann/ } \\
\text { Rottenburg }\end{array}$ & $\begin{array}{l}\text { At the Margins of the South African Lowveld - The Dynamics of } \\
\text { Disputing Processes in Plural Legal Orders }\end{array}$ & 01.04.08 & \\
\hline 19. Lien, Meng-Chi & Taiwan & $\begin{array}{l}\text { Albrecht/ } \\
\text { Hefendehl }\end{array}$ & $\begin{array}{l}\text { Victim-Offender Mediation and the Role of the Public Prosecutor } \\
\text { - A Comparison of Germany, Taiwan, and China }\end{array}$ & 01.04 .08 & \\
\hline 20. Lin, Jing & China & $\begin{array}{l}\text { Albrecht/ } \\
\text { Hefendehl }\end{array}$ & $\begin{array}{l}\text { Compliance and Money Laundering Control by Financial Institu- } \\
\text { tions in China - Self Control, Administrative Control, and Penal } \\
\text { Control }\end{array}$ & 01.09 .09 & \\
\hline 21. Moradi, Fazil & Sweden & Rottenburg/N.N. & $\begin{array}{l}\text { Negotiating Social Justice in Post-Ba'ath Iraq: A Recognition and } \\
\text { Reparation Campaign against the Iraqi State }\end{array}$ & 01.07.11 & \\
\hline $\begin{array}{l}\text { 22. Moura de Souza, } \\
\text { Cléssio }\end{array}$ & Brazil & Albrecht/Perron & Youth and Violence in Brazil: The Reality behind the Rates & 01.10 .11 & \\
\hline 23. Mugler, Johanna & Germany & $\begin{array}{l}\text { Rottenburg/K. von } \\
\text { Benda-Beckmann }\end{array}$ & Organizing Accountability and Criminal Justice in South Africa & 01.04 .08 & \\
\hline 24. Muwereza, Nathan & Uganda & Albrecht/von Trotha & $\begin{array}{l}\text { Retributive vs. Restorative Justice in the Northern Uganda Conflict } \\
\text { - A Case for Selective Justice; the Application of Different Forms } \\
\text { of Criminal Justice }\end{array}$ & 01.08 .10 & \\
\hline $\begin{array}{l}\text { 25. Rojas Paez, } \\
\text { Gustavo José }\end{array}$ & Colombia & Albrecht/Perron & $\begin{array}{l}\text { Transitional Justice from Below: Chances and Prospects in } \\
\text { Contemporary Colombia }\end{array}$ & 01.10 .10 & \\
\hline $\begin{array}{l}\text { 26. Schuetze-Reymann, } \\
\text { Jennifer }\end{array}$ & Canada & Sieber/Perron & $\begin{array}{l}\text { International Criminal Justice on Trial: The Legal Implications } \\
\text { of the Referral Practice of Cases from International to National } \\
\text { Justice Mechanisms - the ICTY/ICTR Experience and its Possible } \\
\text { Relevance for the ICC }\end{array}$ & 01.04 .09 & \\
\hline 27. Solarin, Adepeju 0. & USA/Nigeria & $\begin{array}{l}\text { Rühland (Freiburg } \\
\text { University) } \\
\text { /Albrecht }\end{array}$ & $\begin{array}{l}\text { Restorative Justice Peacemaking Circles: What Relevance to } \\
\text { Intractable Conflicts? }\end{array}$ & 01.09 .11 & \\
\hline $\begin{array}{l}\text { 28. Stahlmann, } \\
\text { Friederike }\end{array}$ & Germany & $\begin{array}{l}\text { Schlee/K. von } \\
\text { Benda-Beckmann }\end{array}$ & $\begin{array}{l}\text { Procedures of Dispute Management in 'Post-War' Times } \\
\text { - a Disputing Parties Account, Bamyan/ Afghanistan } 2009\end{array}$ & 01.04 .08 & \\
\hline 29. Švarca, Inga & Latvia & Wolfrum/N.N. & $\begin{array}{l}\text { The Procedure of the European Court of Human Rights Regarding } \\
\text { Countries in Transition - The ECtHR's Transitional Justice Cases } \\
\text { Against Latvia }\end{array}$ & 01.03 .09 & \\
\hline 30. Terwindt, Carolijn & Netherlands & $\begin{array}{l}\text { Fagan, Povinelli, } \\
\text { Richman (Columbia } \\
\text { Univ.)/Albrecht }\end{array}$ & $\begin{array}{l}\text { Ethnographies of Contentious Criminalization } \\
\text { - Expansion, Ambivalence, and Marginalization }\end{array}$ & 01.08 .09 & Novemb. 11 \\
\hline 31. Vujinović, Lejla & Germany & $\begin{array}{l}\text { Vest (Univ. of Bern)/ } \\
\text { Albrecht }\end{array}$ & $\begin{array}{l}\text { Dealing with War Crimes in Bosnia and Herzegovina } \\
\text { - Transitional Justice Mechanisms, Deals, and Public Perception }\end{array}$ & 01.09 .08 & February 12 \\
\hline 32. Walter, Thomas & Germany & Härter/N.N. & $\begin{array}{l}\text { Legal Responses to Revolts during the French Revolution: } \\
\text { The Case of the Saxon Peasant Uprising of } 1790\end{array}$ & 01.03 .11 & \\
\hline 33. Zhao, Chenguang & China & Albrecht/Eser & $\begin{array}{l}\text { The ICC and China: The Principle of Complementarity and the } \\
\text { National Implementation of International Criminal Law }\end{array}$ & 01.07 .09 & \\
\hline
\end{tabular}




\section{Personal Statements}

\section{Doctoral student's personal experiences with the IMPRS REMEP}

Quotations (doctoral questionnaire, November 2011):

"The interdisciplinary nature of the REMEP program has made me holistically conceptualize criminality from psychological, historical, sociological and legal perspectives.”

"Well funded and independent research. Great liberties, flexibility and adequate level of obligations (such as workshops and Winter Universities). Adequate income. Research budget for fieldwork, conferences, and other expenses available. Excellent infrastructure at the institute (IT, library). Large network of international REMEP students.”

"Very good international contacts to researchers in my field and in legal fields. the name Max Planck helped me a lot to get access to potential interview partners I could attend very good conferences and got to know many relevant people. Multidisciplinary working environment great and very important for my research topic. Wonderful student body. It is so much easier and productive to have such a great group over an extended period of time. We really got on well and helped each other and developed our research projects together. My expectations were fully met. "

"I appreciate the team spirit that evolved among the doctoral students of REMEP and the mutual support we gave/give each other. Furthermore, I enjoy the interdisciplinary character of the REMEP since the experiences and incitements from the faculty members as well as from the doctoral students from the other institutes were very helpful and inspiring for my research.”

"Esp. doctoral students' support (in Halle and Freiburg) and support of Dr. Bertram Turner in Halle.“

"It helps me quickly adapt to the multicultural environment. In REMEP both English and German are spoken, which are both foreign language for me, and they help open new windows with different culture."
"I have experienced so many good chances to attend conference, soft skills, team work which are all helpful for my academic life! The interdisciplinary research methods and concepts helped me a lot to find solutions to my project from different perspectives. With the great help of supervisors and coordinator of REMEP, I made more progress as I have expected from the PhD study."

"Broadening of perspective on respective issues of my topic due to the interdisciplinary composition of the REMEP.”

"Interdisciplinarity, great scientific and personal experiences with REMEP colleagues, excellent library, concentration on my project."

"An improved interdisciplinary understanding of the fields we are working on, furthered by personal contacts and the chance of feedback in order to gain a broader understanding as well as the chance to address a broader scientific audience. "

"Structuring the timeframe available for completing a dissertation. - Exchange with REMEP students and faculty. - Interinstitutional exchange and collaborations."

"Interesting insight in how lawyers think; good ambiance in the workshops."

"Positive: full support in exploring things that will help me succeed in my PHD research."

"In the case of my two last presentations, I got good and helpful feedbacks from the REMEP members."

"From the very first day, I felt that I had come to the right place. I was welcomed warmly not only by the other REMEP candidates, but also by the coordinator and the teaching/supervising faculty. From the start I was provided with all the information I needed to settle in comfortably and to start with my work right away. Everyone is very approachable and if there are ever 
any open questions or problems I know who to turn to and I know I will receive answers/ help promptly. The REMEP spirit is amazing. After only a few days in the research school, my REMEP colleagues already seemed like family, which was also due to the fact that I was able to participate in an introductory workshop during my first week in the research school. The mutual support in the group is remarkable and because we all come from different disciplinary backgrounds, cultures, etc. - our exchanges both on an academic and personal level are invaluable. I know these relationships will last for life. In addition, the availability of support and of resources at the Institute is fantastic. I am able to find everything I need for my work. And while the research school is challenging and demanding, it still leaves me with enough time and space to work on other little projects, such as journal articles or conference papers. In fact, this additional work is encouraged and support is made available for it as well."

"The REMEP research school is embedded in a thriving academic environment and inspirations from other research schools, researchers, etc. abound. It is easy to be inspired in this environment and to exchange views on various topics relating to one's dissertation or not."

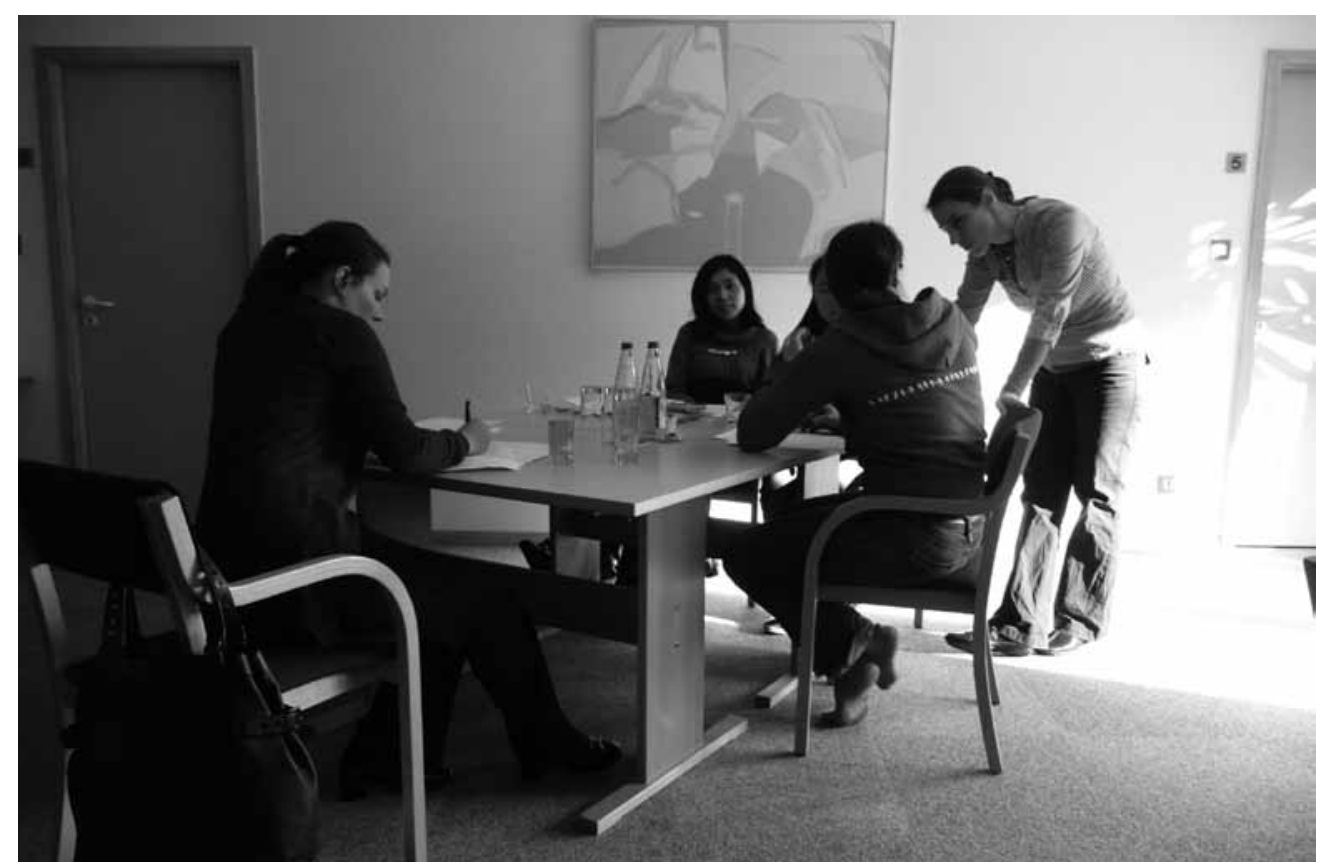




\section{Additional Considerations}




\section{Motivations for Joining the IMPRS REMEP}

The IMPRS REMEP was specifically designed, by means of a close co-operative effort between the two partnering universities and the four Max Planck Institutes to improve the education and training of junior scientists in the interest of all parties. The IMPRS REMEP managed to attract highly-qualified young scientists from Germany and abroad. According to the survey among the doctoral students most explained their motivation to join the IMPRS REMEP because of the subject area and interdisciplinary of the Research School (64\%), followed by the REMEP having an international set-up of the student body (58\%), providing attractive financial support (55\%) and the structured program $(36 \%)$. 35\% also mentioned the reputation of the institutions involved as a motivation of joining the IMPRS REMEP. However, the location of the partnering institutions was of minor importance in their choice to join the research school (4\%). It is worth noting that in the survey $90 \%$ of the doctoral students would recommend the IMPRS REMEP to other doctoral candidates, while $10 \%$ provided no answer. $96 \%$ considered their career options likely to be better in comparison to structured doctoral programs elsewhere.

\section{REMEP University Partners' Commitment to a Continued Cooperation}

Both Freiburg University's Faculty of Law and the Institute for Social and Cultural Anthropology at the University Halle-Wittenberg are partnering in the IMPRS REMP and have agreed to do so in case the IMPRS REMEP will receive funding for another six year period. Cf. F. Appendices, 3. University Partnership Declarations. Therefore, a continued close and excellent collaboration of the University of Freiburg and Halle-Wittenberg with the Max Planck Institutes within the context of the IMPRS REMEP is guaranteed.

The financial contributions of the two partnering universities (1 doctoral position each) as well as the ratio university (2) - Max Planck Institutes (4) might seem unbalanced and is asking for further explanation. However, one has to consider that both in Frankfurt as well as in Freiburg two IMPRS already existed when the
IMPRS REMEP came into being in 2008; the IMPRS for Comparative Legal History (Frankfurt) and the IMPRS for Comparative Criminal Law (Freiburg). Both research schools are bipolar and sponsored by the respective MPI and the local university, only. Especially the financial capacities of the partnering universities do not allow increasing the number of doctoral positions that have been allocated to the IMPRS REMEP from the very beginning. The same holds true for the financial situation at the University Halle-Wittenberg. Until very recently, the rules and regulations for the conferral of doctoral degrees and titles at the Faculty of Law at Heidelberg University have been such to deter foreign doctoral students as well as Germans who wished to write their dissertation in English. Therefore, doctoral students of Prof. Wolfrum did their doctoral degree at Hamburg University's Faculty of Law. 


\section{Doctoral Exams \& Language Issues}

At the Universities of Darmstadt (history), Frankfurt (history), Freiburg (law and sociology), Halle-Wittenberg (social anthropology) and Hamburg (law) dissertations can be submitted in English. The oral exams in Freiburg and Frankfurt, in principle, are taken in German. At the Martin-Luther University Halle and the University of Darmstadt (history) orals

\section{Alumni}

The REMEP alumni continue to be featured in the REMEP brochure and on the REMEP webpage within a special section devoted to them. They are being kept abreast about ongoing events and most welcome to actively participate in upcoming REMEP conferences and workshops. Some of the REMEP students were offered PostDoc positions within the context of REMEP and other research projects at the re- in English are facultative. So far four doctoral students submitted their dissertations in English (Armborst at the Faculty of Philosophy of the University of Freiburg, Jensen at the Faculty of Law of Freiburg University, Terwindt at Columbia University School of Law, and Vujinovic at Faculty of Law, University of Bern).

\section{Social Integration}

Social integration is excellent at all REMEP partner locations. According to the survey 25 doctoral students (72\%) feel welcome and well integrated both within the IMPRS REMEP as well as at their respective partner institution,

spective REMEP partner institutions and are involved in tutoring junior doctoral students. Since the REMEP student network is currently quite strong, we have the expectation to be able to build an equally strong alumni network. According to the survey, $96 \%$ of the doctoral students intend to maintain contact to their colleagues (25 responses) and 88\% (23 responses) to their respective first supervisor.

while 2 persons $(6 \%)$ are unsatisfied with their level of integration and 7 provided no answer (21\%). Language courses are offered at all REMEP locations.

Winter University 2011 Halle/Saale

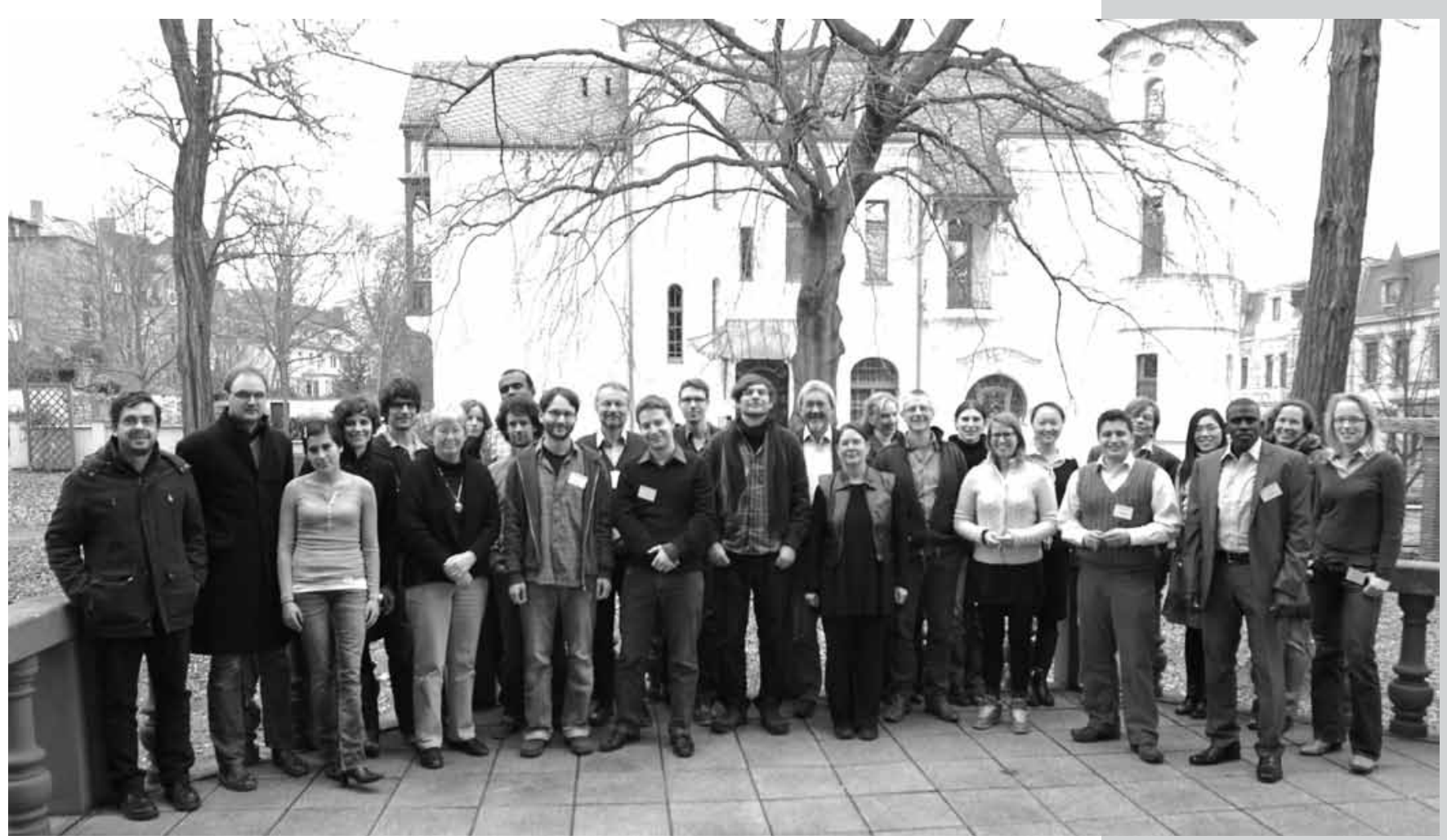




\section{E. Sponsorship and Financial Information}


The Max Planck Society for the Advancement of Science and the partnering universities, University of Freiburg and University of Halle-Wittenberg, share the costs of the IMPRS REMEP.

Both universities provide for one doctoral position each and their professors are very engaged in the course work and supervision of the doctoral students. The Max Planck Society provides the funding for eight scholarships: three scholarships are allocated to the MPI for Foreign and International Criminal Law and the MPI for Social Anthropology, respectively. One scholarship is allocated to the MPI for European Legal History and the MPI for Comparative Public Law and International Law, respectively. In addition, the Max Planck Society provides funding for material costs (for conference attendance, workshops, guest lectures, travel expenses, soft skills training etc) and personal costs.
The partnering Max Planck Institutes co-fund the IMPRS REMEP by contributing scholarships to the IMPRS REMEP: Halle and Freiburg 3 each, Frankfurt and Heidelberg 1 each. In addition, the MPI for Social Anthropology provides extensive funding for the field trips of its doctoral students (18.000 € per doctoral student per field trip) adding up to $162.000 €$ so far.

Furthermore, the so-called cost-benefit calculation ("Kostenleistungsrechnung") reveals that the additional financial contributions (library, IT-support, publishing, administration, premises, general services etc) of the partnering MPI, only, are quite significant; in 2010 e.g., they amounted to $356.857 €$.

Table 1: IMPRS REMEP Budget (MPS)

$2008-2013$

\begin{tabular}{|c|c|c|c|c|c|c|c|}
\hline \multicolumn{8}{|l|}{ 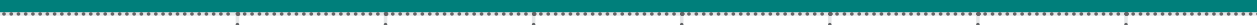 } \\
\hline & 2008 & 2009 & 2010 & 2011 & 2012 & 2013 & Total \\
\hline Personal costs & 70.000 & 70.000 & 70.000 & 70.000 & 70.000 & 70.000 & 420.000 \\
\hline Material costs & 46.000 & 34.000 & 95.000 & 76.000 & 76.000 & 46.000 & 373.000 \\
\hline $\begin{array}{l}\text { Doctoral research } \\
\text { positions }\end{array}$ & 143.000 & 240.000 & 240.000 & 240.000 & 240.000 & 240.000 & 1.343 .000 \\
\hline Total & 259.000 & 344.000 & 405.000 & 386.000 & 386.000 & 356.000 & 2.136 .000 \\
\hline
\end{tabular}


Table 2: IMPRS REMEP Co-Funding (2008-2011) / Sponsoring of Doctoral Research

\begin{tabular}{|c|c|c|c|c|c|}
\hline & 2008 & 2009 & 2010 & 2011 & Total \\
\hline MPI Frankfurt & & & 24.000 & 24.000 & 48.000 \\
\hline MPI Freiburg & & 72.000 & 72.000 & 72.000 & 216.000 \\
\hline MPI Halle & & & 48.000 & 48.000 & 96.000 \\
\hline MPI Heidelberg & & 22.000 & 24.000 & 2.000 & 48.000 \\
\hline University Halle* & 9.000 & 12.000 & 12.000 & 3.000 & 36.000 \\
\hline University Freiburg* & & 4.000 & 12.000 & 12.000 & 28.000 \\
\hline Total & 9.000 & 110.000 & 192.000 & 161.000 & 472.000 \\
\hline
\end{tabular}

* Via third-party funding.

Table 3: Annual Expenditure 2008-2011 (against MPS funding only)

\begin{tabular}{|c|c|c|c|c|c|}
\hline & 2008 & 2009 & 2010 & 2011 & Total \\
\hline Personal costs & 55.100 & 39.000 & 32.600 & 58.279 & 184.979 \\
\hline Material costs & 66.806 & 41.700 & 83.500 & 66.769 & 258.775 \\
\hline $\begin{array}{l}\text { Doctoral research } \\
\text { positions }\end{array}$ & 134.800 & 238.800 & 263.500 & 264.209 & 901.309 \\
\hline Total & 256.706 & 319.500 & 379.600 & 389.257 & 1.345 .063 \\
\hline
\end{tabular}




\section{F. Appendices}

1. Doctoral Research Projects 


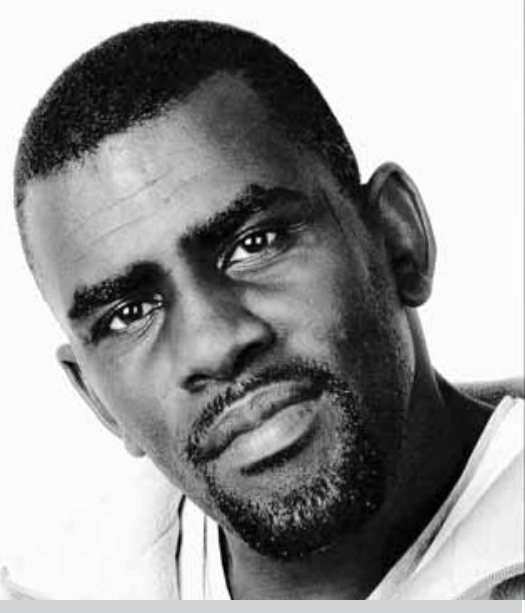

Mr. Zahir Musa Abdal-Kareem is a Sudanese citizen. In May 2010, he was admitted to the IMPRS REMEP at the MPI for Social Anthropology at the age of 37. Zahir had obtained a B.Sc. degree in Sociology and Social Anthropology from Khartoum University, Sudan, in 2000 and a M.Sc. degree in Social Anthropology from Khartoum University in 2010 . He is funded by the Max Planck Institute for Social Anthropology (department 1). The conclusion of his doctoral thesis is expected for April 2014. Zahir is enrolled and a doctoral candidate at the Faculty of Philosophy I at Martin-Luther University Halle-Wittenberg. Prof. Dr. Günther Schlee and Prof. Dr. Richard Rottenburg are his supervisors.

\section{Publications:}

- Abdal-Kareem, Zahir Musa: The trajectory of farmers-pastoralists relations in Mornei, West Darfur State. An un-published paper presented in the second workshop about Micro-Macro issues in Peace building in Sudan. Ahfad University for Women, 6-7 November 2006.

- Abdal-Kareem, Zahir Musa: The Ruling Political Elites in the Sudan: Death of Conscious or Absence of State organizations. A published essay in Ray al-Sha'ab Newspaper, August 2006.

\section{Processes of Ethnic Identification in the Course of Land-Based Conflicts in South Gedaref State, Eastern Sudan}

The study investigates the issue of identification in relation to land-based conflicts in south Gedaref state, Eastern Sudan. This issue is classified within the topic of 'identification in the course of conflict situations'. The study is divided into two main general themes: land based conflicts and the processes of ethnic identification that are related to it.

Processes of identification will be studied through the question of nomad-sedentary relations together with its connections to land issues in south Gedaref state. Issues like access to, use and management of land resources and the extent to which they take part in the onset of conflicts at the local level will be dealt with as well. On the one hand, conflicts between farmers and pastoralists; farmers and farmers, and; between pastoralists and pastoralists will be investigated. On the other hand, conflicts between owners of big mechanized farming projects versus 'farmers and pastoralists in $\mathrm{Ge}$ daref' will also be tackled.

Likewise, the different economic, administrative, political and socio-cultural aspects underlying land based conflicts will be taken into account. This study argues that the final outcome of what we see today, regarding the issue of farmers' pastoralists' relation in this area, is automatically a combination of these above-mentioned different aspects. This study presumes that, within the context of Gedaref rural areas, some factors have necessarily played more significant roles than other. Key questions: are land-based conflicts affected by land overutilization and; thus, should the study put more emphasis on the issue of land management? And is this land overutilization, if it exists at all, triggered by demographic factors or by the realities that have been created by the introduction of the intensified technology in this area? However, more focus will be paid to the subject of conflict management rather than resource management. That means the question of how farmers and pastoralists deal with the issue of the access to the natural resources, land in particular, together with the overall socio-cultural structures within which they are imbedded will be handled as well.

Issues that are related to the crisis of governance in Sudan, including the autocratic leadership, corruption, inadequate national policies and the use and control over resources at the national state level will be examined. Accordingly, the study will try to relate the processes at the grass-root level to wider economic, administrative and political contexts in which they are entrenched.

The question of the legal dimension of land issues and to what extent it has contributed to the emergence of the conflicts in this area will be scrutinized. Here, the study will try to examine whether there is a contradiction within the dominant pattern of land tenure system in this area. More specifically, light will be shed on the two very important issues of the customary, as well as the statuary land tenure systems.

Other important aspects that are connected to the roles played by commercialization together with the expansion of both livestock and farming activities, including the introduction of mechanized farming projects, in Sudan will be handled. Here, the questions of to what extent/ and how have farmers and pastoralists been integrated into the international world economy; and what are the implications at the grass-root level will be considered also Concerning the second issue; processes of ethnic identification, this study adopts the notion that focusing only on the issue of natural resources - land in this study - is not sufficient to have an adequate analysis for the conflict phenomenon. 


\section{Vigilant Eyes: Exploring the Role of Voluntary Citizen Surveillance in Controlwork}

This PhD project investigates and analyzes contemporary forms of voluntary citizen surveillance and their role in controlwork - a term that Hille Koskela uses to refer to the practices undertaken by a range of agents to maintain social control, both for their own purposes and to further official control agendas. In recent years, the creation and mobilization of a well-informed, proactive, and vigilant public has become not only a hallmark of the exceptional politics of the U.S.led War on Terror, but also of everyday practices of crime and social control. Authorities have increasingly encouraged the public to act as the "eyes and ears of law enforcement" and to participate in various forms of surveillance and reporting of any unusual or suspicious objects, people or circumstances. Examples include the popular "If you see something, say something" campaign that was launched in New York City in 2002, the Texas Virtual Border Watch Program and the London Metropolitan Police's recent public call to identify and report rioters. Many of these campaigns to recruit citizens as vigilant eyes in controlwork are geared towards the anticipation of events, deploying a kind of precautionary principle that governs through the suspicion of a possible future threat. Here, the assumption is that the probable future actions of a potential offender are somehow already visible in the traces of everyday life and that these traces can be identified and rendered intelligible through the eyes of not only trained police officers but ordinary citizens. The "responsible" citizen is asked to monitor for suspicion throughout his or her routine, everyday activity, to recognize abnormality and, acting as a petty sovereign, to make security decisions. Some of these initiatives, however, are also run by private citizenobservers themselves who create their own websites in order to report and publish images of actual or imputed transgressions. As a result it is becoming increasingly difficult to deline-

Literature:

Andrejevic, M. (2005). The Work of Watching One Another: Lateral Surveillance, Risk and Governance, Surveillance \& Society 2(4), 479-497. ate between the authorities and the public, the controllers and the controlled, the watchers and the watched. In fact, the participatory injunction extends monitoring techniques to such an extent that some researchers already speak of a "rising culture of informing" (Doyle 2006) or the cultivation of "citizen spies" (Andrejevic 2005). Yet, thus far, these forms of citizen surveillance have received little scholarly attention and existing surveillance theory seems inadequate to capture them conceptually. One objective of the project is therefore to develop a theoretical and conceptual framework for understanding these particular phenomena. To this end, it explores the relationship between the authorities and the public in these arrangements and analyzes underlying governmental rationalities. It examines the specific embodiment of the citizen that the discourses of responsibilization and vigilance produce and how the figure of the prudent citizen is delineated from the marginalized, irresponsible Other. Further, the proposed research examines the specific forms that public participation takes, as well as the motivation of those who engage in these vigilant practices. In what way and by whom is involvement in these vigilant activities legitimized? What are the justifications put forward by the citizenobservers for why they are engaging in these forms of voluntary private surveillance? What imaginations of justice, punishment, morality, order and citizenship can be found in their discourses? And how do these imaginations differ from the imaginations and expectations of the official criminal justice system? Which emotions are relevant when it comes to these types of voluntary citizen surveillance: Anxiety? Revenge? Voyeuristic pleasure? Boredom? Finally, the project also considers the impact that these participatory schemes have on the communities and target populations, as well as possibilities for subverting them.

Doyle, A. (2006). An Alternative Current in Surveillance and Control: Broadcasting Surveillance Footage of Crimes, in K. Haggerty and R. Ericson (eds) The New Politics of Surveillance and Visibility, Toronto et al: University of Toronto Press, 199-224.

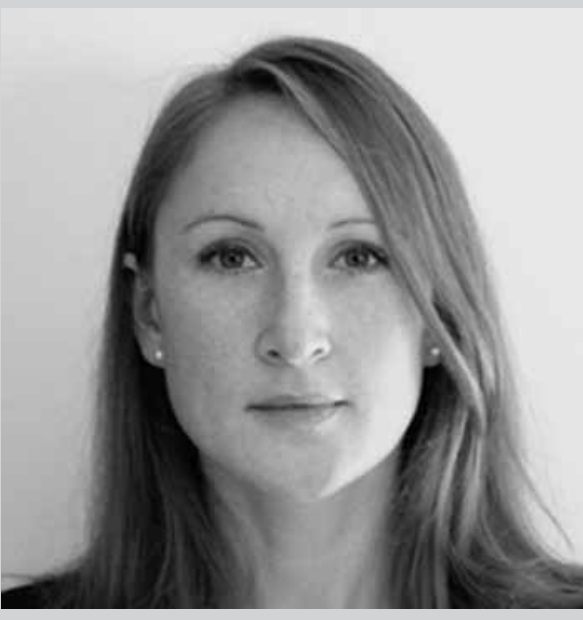

Ms. Kerrin-Sina Arfsten is a German citizen. In June 2011 , she was admitted to the IMPRS REMEP at the MPI for Foreign and International Criminal Law at the age of 31. Kerrin-Sina obtained a B.A. in Sociology and French from Bates College, Lewiston, ME, USA, in 2002, and a M.A. in International Criminology from Hamburg University, Germany, in 2008. She is funded by the Max Planck Society. The conclusion of her doctoral thesis is expected for May 2014. Kerrin-Sina is enrolled at the faculty of philosophy at Freiburg University. Prof. Dr. Hans-Jörg Albrecht and Prof. Dr. Susanne Krasmann, Institute for Criminological Research at the Department of Social Sciences of the University of Hamburg, are her supervisors.

Publications:

- Arfsten, Kerrin-Sina: Aspekte des Grenzvigilantismus (working title). In: ForumRecht, forthcoming 2012.

- Arfsten, Kerrin-Sina: The Minuteman Civil Defense Corps: Border Vigilantism, Immigration Control and Security on the U.S. - Mexican Border. Hamburger Studien zur Kriminologie und Kriminalpolitik Bd. 48. Berlin, LIT Verlag, 2010. 


\section{Andreas Armborst \\ Jihadi Violence - A study of al-Qaeda's media}

Retaliation and punishment are strong motives in the violent campaign of jihadi groups. From their point of view they react justly to the perceived anomic conditions of Islamic societies. This worldview is articulated in the jihadi movement's ideology and media. This study analyses communiqués of al-Qaeda and affiliated groups with a focus on the question: What does jihadi media say about the motivation, justification, adequacy and expected outcome of violent action? The method of explorative and relational content analysis (using the software MAXQDA) is used to identify and map the different narratives, themes and issues of 31 statements of three al-Qaeda leaders (Usama bin Laden, Ayman al-Zawahiri, and Abu Yahya al-Libi). The results show that al-Qaida has created a complex worldview that touches upon a plethora of theological and political issues.

The blending of theological and political argument is salient throughout the jihadi media. Political claims and grievances are skillfully backed by journalistic evidence, whereas theological arguments are complemented by legal references to the Quran and Sunna. In addition, the jihadi leaders provide doctrines and strategies describing how the use of force can defend
Islam against its three existential threads - the global conflict, apostasy, and secular governance. Theological and strategic considerations converge in al-Qaeda's rationale for violence.

The ideological implications of jihadism materialized in Iraq after the US invasion in March 2003. Content analysis of claims of responsibilities issued by jihadi groups in Iraq indicates that there is an ideological convergence, divergence and innovation to the salafi-jihadi doctrine of AQ central.

In addition to the empirical findings, the study seeks to gain three other academic benefits for researching political violence and terrorism: First, it provides a model of terrorism that bypasses some of the crucial problems academics have faced when defining this contested term; second, it compiles some of the most important academic writings about the jihadi movement into a 'digest of jihadism' that standardizes terminology and gives a brief and comprehensive overview of disparate information; third, it develops a methodological approach to systematically map the content of a given ideology and to monitor its developments.
Andreas is currently working as a researcher involved in the project "BaSiD" (Security, perceptions, reports, conditions and expectations - Monitoring Security in Germany) at the MPI for Foreign and International Criminal Law.

\section{Publications:}

- Armborst, Andreas: Jihadi Journalism. In: Aurélio, D P. / Proença, J. T. (eds.): Terrorism: Politics, Religion, Literature. Cambridge, Cambridge Scholars Publishing, 2011 , p. $115-128$.

- Armborst, Andreas: Modeling terrorism and political violence. In: International Relations 5, 2010, issue/volume 24/4, p. $414-432$.
- Armborst, Andreas: Jihadism, terrorism and the state. In Armborst, A., Jensen, D. (eds.): Retaliation, Mediation and Punishment. edition iuscrim, forschung aktuell - research in brief, no. 42. Freiburg i. Br. 2010, p. 5-13.

- Armborst, Andreas: A profile of Religious Fundamentalism and Terrorist Activism. In: Defence Against Terrorism Review, 2009, Issue/Volume 2/1, p. 51 - 71. 


\title{
The Politics of Order
}

\author{
An Analysis of Punishment in International Law
}

The sudden 'boom' of global criminal justice and the subsequent extension of principles and procedures of criminal law into the international realm are part of a broad historical era in which international law has turned to ethics. As such, punishment as a legal discourse is built on an universal and anti-formalist moral vocabulary, which currently functions on the premises of overwhelmingly Western ideas of criminal justice and international politics.

Arguments in support of international criminal justice often refer to "deterrence," "national reconciliation," or recovering the "dignity of the victims." Yet these justifications are ambiguous, they are rarely articulated with sufficient concreteness so as to measure their implementation in practice. First of all, it is not always clear that the pursuit of criminal trials is the most efficient means to effect peace and national reconciliation. As many diplomats have argued, the prospect of trials may aggravate conflicts and make settlement more difficult. In national societies, criminal law is usually justified by reference to the deterrent effect criminal punishment is expected to have. It is unclear whether any such deterrent effect may be assumed at an international level, especially if the trial is held by foreign judges at a geographically distant location. Studies on the attitudes of populations in the former Yugoslavia do not give much support to the view that an international trial might have a significantly positive effect on political reconciliation.
The research project sets out to describe and provide an understanding of the current process of criminalization of international law and to present an assessment of the underlying conditions and rational in which punishment generates, performs, and reproduces a particular form of political international order. In this framework, punishment is taken as a discursive institution; as a set of narratives constructed upon legal and quasi-legal arguments about what, whom and how to punish. In this view, it operates as a collection of "active" categories and procedures with the capacity to "speak of" the social world and deliver authoritative classifications.

The objective of this research is to contribute with a reasoned account of how the mechanics of punishment are employed by international actors in a highly political international community, and to discuss the effects of this criminalization in the construction of social political order.

This investigation is interdisciplinary and aims to approach the topic of punishment in international law by looking beyond classical legal standpoints. As such, drawing from postmodern theory, it seeks to incorporate and combine angles from criminology, deconstruction theory, philosophy of law, and philosophy of culture.

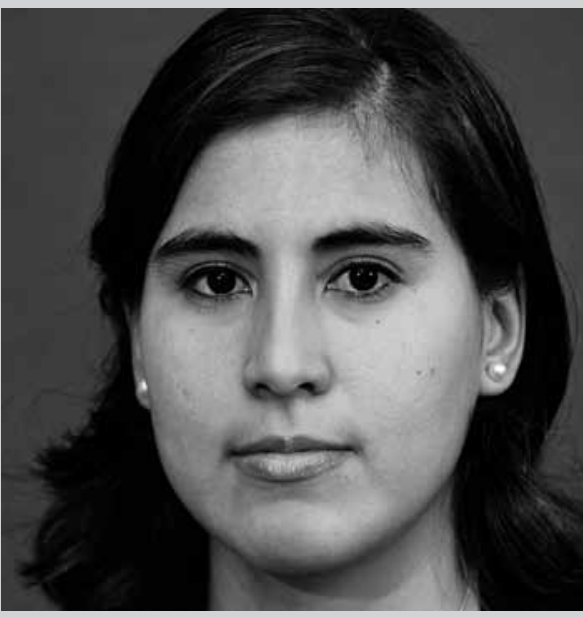

Ms. Shakira Bedoya Sanchez is a Peruvian citizen. In April 2008, she was admitted to the IMPRS REMEP at the MPI for Foreign and International Criminal Law at the age of 28. Shakira had received an LL.B. from the Pontifical Catholic University, Peru, in 2005. She was then admitted to pursue doctoral studies at the Eric Castrén Institute of International Law and Human Rights at the University of Helsinki, Finland, where she completed graduate courses during 1.5 years. She is enrolled at the faculty of law at Freiburg University. She received a scholarship by the Max Planck Society. The conclusion of her doctoral thesis is expected for the Summer Term 2012. Her supervisors are Prof. Dr. Hans-Jörg Albrecht and Prof. Dr. Martti Koskenniemi, director at the Erik Castrén Institute of International Law and Human Rights at the University of Helsinki, Finland. Her day-to-day supervisor is Mr. Jan-Michael Simon, senior researcher at the MPI for Foreign and International Criminal Law.

Shakira was a visiting scholar at the Lauterpacht Centre for International Law (University of Cambridge) from January to April 2011. In October 2011 she conducted research at the MPI for Social Anthropology in Halle. 


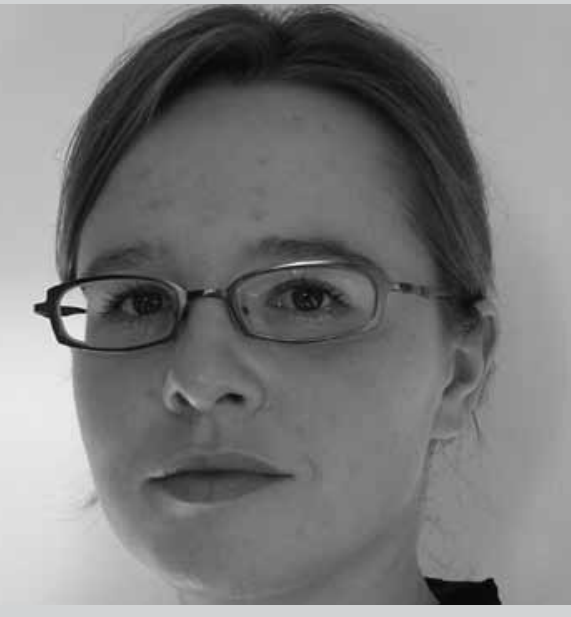

Ms. Stefanie Bognitz is a German citizen. In April 2011, she was admitted to the IMPRS REMEP at the MPI for Social Anthropology at the age of 28. Stefanie had received an M.A. in Social Anthropology from the University Halle-Wittenberg in 2010. She is enrolled as a doctoral student at the University Halle-Wittenberg. Stefanie is funded by the Max Planck Society. The conclusion of her doctoral dissertation is expected in March 2013. Prof. Dr. Richard Rottenburg is her supervisor.

Stefanie will do her fieldwork in Rwanda from March 2012 until February 2013.

\section{Stefanie Bognitz}

\section{Rights-Based Organizations and Legal Aid as Itineraries of Justice in Post-Conflict Rwanda}

Over the last two decades, considerable attention has been directed to a 'new humanitarianism' in democracy, development, and human rights in the discourse of 'global justice.' This discourse materializes in a transnational metacode of human rights and amplified voices that call for universally accessible organizations and institutions to promote justice. Rights-based activism is translated from a global human rights and justice metacode to local arenas of legal intervention and is expected to produce new material regimes, socio-public orders, and political stability in countries like Rwanda. Aspirations such as 'access to justice' and 'advocating justice' have become catch phrases and are both the mission and vision represented by legal interventions of rights-based organizations.

The post-genocide state of exception fuelled interventions driven by the international community, has led to the proliferation of rights-based organizations with transnational affiliations and a strong agency to restore social order. The research project assesses the justice sector in Rwanda, which has been reconfigured by civil and (para)legal expertise to shape new organizational forms of justice. This materializes within the legal-political framework of post-transitional justice where memory, truth, reconciliation, and justice are permeated by resentment, mistrust, and silence. At the centre of the empirical fieldwork is the question of access to justice, namely legal aid within the organizational framework of legal aid clinics which allocate legal aid, spread ideas of justice, and instruct citizens about their rights. Situated at the core of juridification processes, the idea of justice has spread to the local context, where rights education emancipates legal subjects and encourages public consciousness about rights and entitlements of Rwandan citizens.

These sites of justice advocacy, together with new forms of legal expertise such as paralegals, emerge as noteworthy passage points in the translation of injustice to legalized claims and are thus significant for the empirical research. The aim of the research project is to analyze the enforcement of the rule of law and good governance by means of increasingly legalized processes of dispute resolution and conflict settlement inscribed in legal documents and translated in (court) cases. However, this enforcement must be realized within the scope of rights-based organizations that permeate the justice sector and often have a strong affiliation to state institutions. Juridification that goes along with reconfigurations of the justice sector in Rwanda is expected to nourish frictions between established forms of conflict mediation, as well as localized forms of conflict settlement and emerging legalized interventions of rights-based organizations that challenge traditional hierarchies and the embeddedness of local (legal) authorities in respective communities.

The following guiding questions will be considered:

- How do rights-based organizations and state institutions contribute to the project of juridification?

- How do notions of retaliation and punishment materialize in interventions of rightsbased organizations and how are they embedded in the process of juridification and formalization of the justice sector?

- How are forms of global human rights activism and interventions translated and adapted in local, legal-political arenas occupied by rights-based organizations?

- How do juridification, emerging legal epistemic communities, and contestations of the rule of law contribute to the project of reconciliation and conflict prevention after transitional justice? 


\section{War Crimes Trials in the French Occupation Zone in Germany (1945-1953)}

After the Second World War, between 1946 and 1953, the French Military Government Courts convicted 2130 nationals of the defeated Axis Powers. The trials were based on the Allied Control Council Law Number 10 and concerned staff of concentration camps, members of the Gestapo and police forces, as well as industrialists. The project is based on the analysis of court records, collected and structured with the help of an electronic database. Political sources (Generalia) and private records of legal actors will complete the study. A survey of the verdicts allows one to systematize three complexes of crimes:

- crimes related to concentration camps and sub-camps

- crimes related to forced labour

- crimes committed by state officers, in particular, by policemen and guards

In the trials, the judges applied diverse norms to adjudicate these crimes, but the verdicts were influenced by other factors such as the status of the victims or the hierarchical position of the perpetrators. The project aims at the analysis and explication of these heterogeneous court practices dealing with war crimes and crimes against humanity. A basic assumption is that the jurisdiction of the special tribunals was a result of the occupation of Germany and Germany's subsequent loss of sovereignty. Furthermore, the political character of this jurisdiction could be seen as constitutive. In this respect, the study understands the Allied tribunals as a type of legal discursive arena in which retaliatory conflicts occurred with regard to the atrocities committed against French citizens. With regard to the performative, narrative and medial dimensions of the trials, the study asks how the French legal authorities dealt with Nazi crimes within this framework and addresses the following questions:

1. How did the French prosecutorial program emerge? Which international criminal law norms were applied by the French government tribunals?

2. What role did the Vichy-Syndrome (Willis) play? How could the need to distance France from the politics of wartime collaboration have been related to the thoughts and actions of legal actors during the proceedings?

3. How could the need to forge a (founding) myth of a judging nation be related to the experience of legal actors?

4. What was the frame of reference of the legal actors? How did they refer to the experience of the military justice in France and to the American and British prosecution of war crimes in Germany?

The study focuses on the mentalities and practices of the prosecutors using selected trials in which defendants were accused of crimes against humanity. Exemplary case studies will explore the theoretical background of the prosecutors and their legal practices in court. The study makes use of historical discourse analysis to deconstruct norms, institutions and practices of the war crimes trials. As a result, the project lays the emphasis on the interplay relationship between non-juridical discourses and courts and pays special attention to the role of expert's reports in the construction of legal knowledge about Nazi violence.

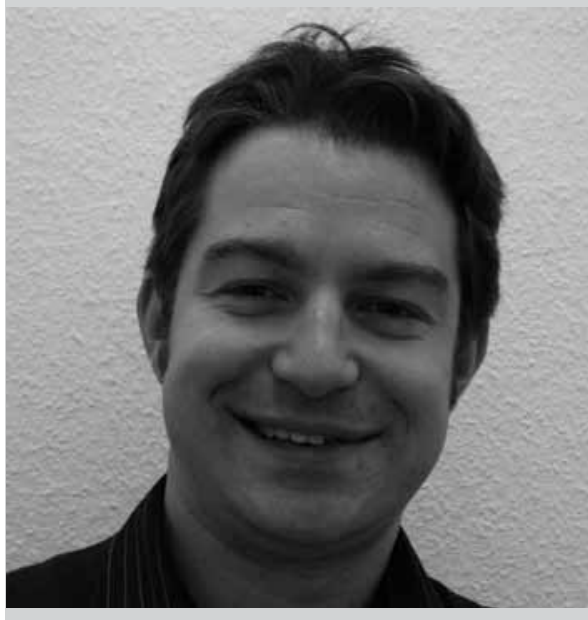

Mr. Daniel Bonnard is a Swiss Citizen. In April 2010, he was admitted to the IMPRS REMEP at the MPI for European Legal History at the age of 26. He received an M.A. in Early Modern History from the PhilippsUniversity Marburg. Daniel is funded by the MPI for European Legal History and also working at the International Research and Documentation Center for War Crimes Trials (ICWC) at Philipps-University Marburg, Germany. He is enrolled as a doctoral student at Marburg University and is expected to conclude his dissertation at the end of 2013. Prof. Eckart Conze, professor for early modern history at Marburg University, and Prof. Dr. Karl Härter are his supervisors.

Daniel organized the conference "Anthropologie historique des pratiques de violence de masse" (Journées d'étude francoallemandes de doctorantEs en sciences humaines et sociales) at Maison Heinrich Heine, Cité Universitaire Internationale, in Paris on 25.-26. November 2011. 


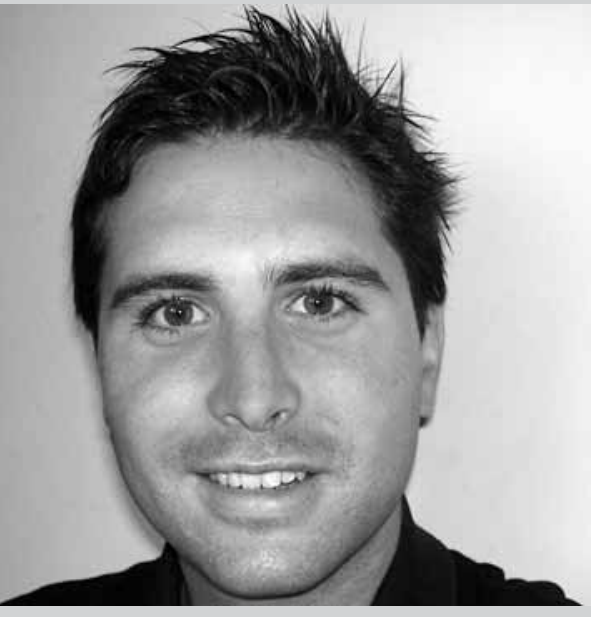

Mr. Juan Benito Cañizares Navarro is a Spanish citizen. In April 2008, he was admitted to the IMPRS REMEP at the MPI for European Legal History at the age of 23. Juan obtained his law degree from The University of Valencia, Spain in 2007. He received a scholarship by the Max Planck Society. He concluded his dissertation and received his academic title from the faculty of law at the University of Valencia, Spain in July 2011. Prof. Dr. Kar Härter and Prof. Dr. Aniceto Masferrer, Professor for Legal History and Comparative Law at the University of Valencia, were his supervisors. Juan is currently Profesor Colaborador Doctor europeus at Universidad Cardenal Herrera - CEU, Spain.

Juan was co-organizer of the congress "Law and historical development from a comparative perspective”, European Society for Comparative Legal History, Inaugural Conference, Valencia, Spain in July 2010.

\section{The Protection of the Honour and Dignity of the Convicted in 19th Century Europe: the Penal Regulations in France and Spain}

At the present day all European countries prohibit the infliction of inhuman or degrading penalties, and France, Germany and Spain provide examples of these protections to ensure the basic rights of people to honour and dignity. Even though many countries have not stated an explicit prohibition of inhuman or degrading penalties in their respective constitutions, the penal practice of all European countries follow the principle that punishment should not damage the honour and dignity of delinquents. However, this was the result of a long lasting, sometimes ambivalent historical development which started with the Enlightenment and influenced the revolutionary and Napoleonic French criminal codification as well as the following criminal codes and laws in many European states. For example, carcan, dégradation civique and bannissement were considered infamous forms of punishment in the Penal Code of 1791, the Code des délits et des peines of 1795, and the Napoleonic Penal Code until they were repealed in 1994 (except for the punishment of carcan, which was already abolished in 1832).

The aim of the project is to reconstruct the history and development of "inhuman or degrading penalties" with regard to the protection of the honour and dignity of convicted and delinquents. Though every crime could breach the honour and dignity of the affected person, the vagueness, the extent and the concrete literature written about this content obliges us to limit the object of the research project to the penalties. It focuses on the honour and dignity of the people that have been found guilty of perpetrating an offence and as delinquents belong to a category of people whose honour and dignity could be easily violated or damaged through the criminal procedure and above all the applied penalty and the concrete execution of punishment aiming at public humiliation. In this regard the question of punishment is closely interlinked with the problem of retaliation but takes also into account that honour (of victims as well as of convicted/delinquents) is "mediated" through the agents of the criminal justice system as well as the public.

The research project is conceived as a case study focusing particularly on the protection of honour and dignity of the convicted in the French and Spanish criminal law traditions from the 18th century until the First World War. It studies the legal and anthropological notion and use of honour in criminal law and the legal discourses concerning the penalties that were considered dishonourable, harmful or shameful for the convicted people. As a result the study scrutinizes the ambivalent development of the purposes and practice of punishment in the age of codification, which still could humiliate convicted in a retaliatory manner, but based on a human and rational criminal law should no longer damage the honour and dignity of convicted members of the civil society. 


\section{Competing Practices in Conflict? How nomadic Fulbe in the Far North Province of Cameroon (b)order their world}

In this PhD thesis I analyze how different natural resource users in an unpredictable semi-arid climate seasonally exploit shared resources with various techniques, thereby balancing between conflict and cooperation. The state and traditional authorities, though present, often do not offer reliable institutions to manage emerging conflicts. I argue that a focus on the creation of borders, which order identities and practices organized by different logics and ends, can help to understand why conflicts nonetheless rarely escalate in this research area, as opposed to other regions.

The research area corresponds to the transhumance axis of nomadic Fulbe cattle herders in the Far North Province of Cameroon. The herders seasonally move between the Logone Floodplain, where they spend the dry season, and Mayo Kani, where they spend the rainy season. The plains of the Diamare constitute an area of transition connecting these two seasonal areas. Along this axis the nomadic Fulbe seasonally meet with other resource users with different livelihood practices in varying sociopolitical and ecological contexts. While in the rainy season area there is a situation of land scarcity, during the transhumance and in the dry season the cattle rather have a problem of access to pastures.

In this research, I contribute to the debate on how social order emerges out of the relations between people and practices with different logics. I thereby not only focus on land as a potential source of conflict, but also on mobile resources, like livestock, which are crucial in the relations between all resource users, both as a potential source of conflict as well as in the creation and maintenance of relations.

The main concept of analysis will be the continuous process of defining and creating borders both in a material and symbolic form, in order to divide who is with whom, what belongs to whom and how different practices of pastoralism, fishing, herding and thieving are connected and divided in space and time. It shows that sometimes borders serve to connect and at other times divide identities, depending on the practices at hand. Due to the unpredictability of the ecological and socio-political context, the nature of these borders is not fixed in time and space but has to be continuously re-legitimized with a wide range of legal and ideological discourses. Moreover, these borders are not only contested between the resource users, but between state and traditional authorities as well, due to the diverging interests of their representatives. Therefore, borders have to be analyzed in their contested function of dividing people and practices but equally in their function of connecting them; thus embodying a network of both human and non human entities and ordering practices and people over time and space.

The argument described in the $\mathrm{PhD}$ is that conflicts over shared resources and the way the parties manage these conflicts can be better explained by how the parties mutually create and contest the borders which connect and divide their practices, and especially under which conditions they use which kind of strategies. To do this, I use comparative methods to show how the different ecological and socio-political constellations of the different seasonal areas interact with the way borders between practices and groups are created and how conflicts over contested borders are managed.

I thereby show how the different conflict resolution mechanisms like retaliation, mediation, arbitration and adjudication are strategically used in specific socio-political and ecological conditions and how new normative and legal discourses are continuously recreated in order to legitimate the resurging order.

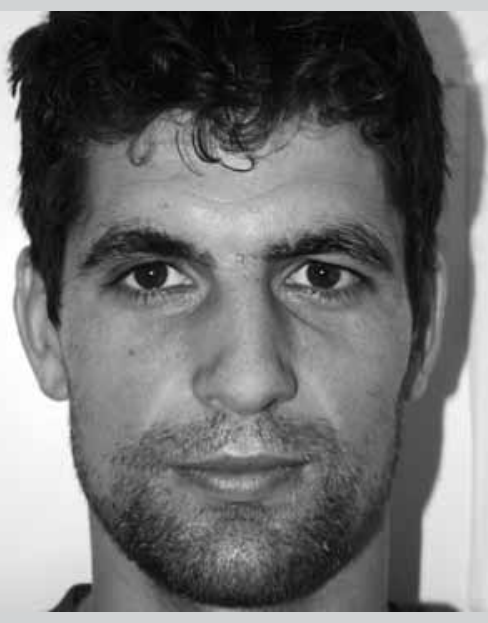

Mr. Ab Drent is a Dutch citizen. He was admitted to the IMPRS REMEP at the MPI for Social Anthropology in April 2008 at the age of 29. In 1998 he received an "Aide Médico Psychologique" (AMP) from the Association Régionale d'Alsace des Formations au Travail Éducatif et Social (IFCAAD), Strasbourg, France. In 2005 he obtained a M.Sc. in Social Anthropology from Wageningen University, The Netherlands. Ab received funding by the Max Planck Society. The conclusion of his doctoral thesis is expected for April 2012. $\mathrm{Ab}$ is enrolled at the University Halle-Wittenberg. Prof. Dr. Günther Schlee and Prof. Dr. Keebet v. Benda-Beckmann are his supervisors.

He has done his fieldwork in Cameroon from January 2009 to January 2010. 


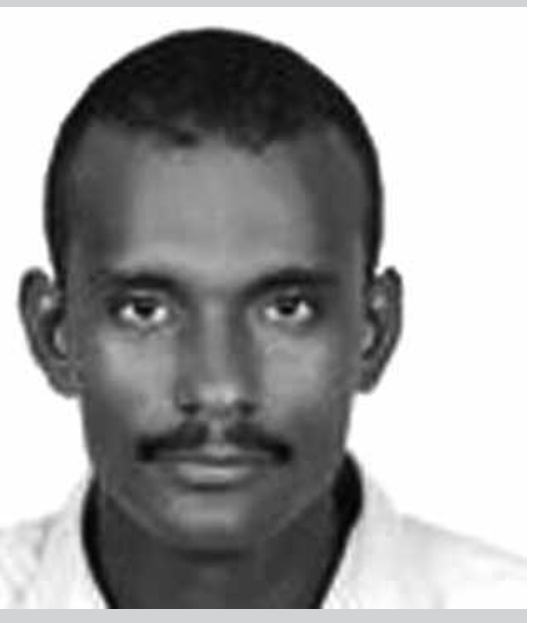

Mr. Ghefari Elsayed is a Sudanese citizen. In April 2008, he was admitted to the IMPRS REMEP at the MPI for Social Anthropology at the age of 37. Ghefari obtained a B.Sc. degree in Sociology and Social Anthropology from the University of Khartoum, Sudan, in 1999. In 2006 he obtained an M.Phil. degree in Anthropology of Development from the University of Bergen, Norway. He was financed by the Graduate School Society and Culture in Motion - University Halle-Wittenberg. Since April 2011 Ghefari has a tutorship at the University Khartoum, Sudan. The conclusion of his dissertation is expected for the end of 2012. Prof. Dr. Richard Rottenburg and Prof. Dr. Günther Schlee are his supervisors.

Ghefari has done his fieldwork from May 2007 - June 2008 in South Kordofan State.

\section{Dispute and Dispute-Settlement in Post-War South Kordofan, Sudan}

The most important recent development in South Kordofan was the Civil War (19832005), which was part of the ongoing Sudanese national state crisis. After the Comprehensive Peace Agreement (CPA) of 2005, new sorts of conflicts developed. It is reported that more than 100 different areas are shaped by conflict or tension all over South Kordofan. Applying customary mechanisms of conflict resolutions is recommended by Civil Society Organisations and international actors like NGOs as part of the crisis management in the disturbed region.

This study focuses on dispute and dispute settlement in post war South Kordofan. Besides dispute resolutions at local courts, where different legal repertoires come together, also other institutions, networks, and narratives relevant to conflict and conflict management will be examined. The customary laws that will be examined have been objects of negation, manipulation, and accommodation during various historical periods, political regimes, and ideological orientations on the local, the national, and the international level.

The last civil war led to the emergence of opposed political units defined by ethnic criteria. The sense of ethnic unity and distinctiveness among the Nuba became much more pronounced during the difficult war years. The political struggle against Arab domination and political Islam reached a decisive moment when some of the Nuba leaders, many of them Muslims, decided to join the Sudan People's Liberation Movement/Army (SPLM/A) in its war against the Islamic government of Sudan in 1984. Afterwards, most of the Nuba became supporters to this secular movement led by southerners fighting to establish the "New Sudan" as a modern, democratic, secular, and federal state. While this war was taken to the north of Bahr-El-Arab, the government distributed automatic weapons to the Baggara Arabs, presented itself as their protector, and staged all this as its „Islamic Project". In this context the ethnic category „Hawazma“ slowly emerged as a political unit engaged in a struggle for power sharing.

While it is hard to establish the exact beginning of state failure in the Sudan, this process became obvious after 1989. Nowadays, the state fails to mobilise the legitimate use of power within its borders. The police and other state institutions are either weak or more or less completely absent, as in South Kordofan. Accordingly, other political units and mechanisms emerge and constitute semi-autonomous social fields of non-state actors. It is in this context that conflict management and dispute resolution are the persisting questions in South Kordofan today. Part of the problem is that the political units constitute themselves as ethnic units founded on autochthony.

This study aspires to contribute to the current debate on the functions and interrelations of retaliation, mediation, punishment, and reconciliation in a post-war situation, where people - not able to rely on a functioning state - want to and have to find ways of overcoming the wounds they have inflicted upon each other through enormous atrocities. In this context, questions of collective responsibilities are raised and these, in turn, are often defined ethnically. Thereby, tragically, former acts of hostility are after the event attributed to local actors, tribes, and ethnic groups, when in fact they were caused by political parties, religious networks, and the government.

Some of the concrete questions of this study are the following: What exactly are the traditional conflict management mechanisms and how were they developed through-out different historical periods? What is the impact these mechanisms have on inter-group relations? How does legal pluralism affect these traditional mechanisms? How are these mechanisms relating to the state, identity politics, and competition over scarce resources? 


\title{
Invocations of Reciprocity and Patterns of Accumulation
}

\author{
Integration and conflict in the Ateker region of Northeast Africa
}

Retaliation, mediation and punishment as key forms of human interaction and as concepts of interpretation are closely related to the notions of justice and reciprocity. With my research project I intend to illustrate this relation for the case of a North-east African region where two very different socio-cultural models - traditional (semi-)nomadic pastoralism and the globalised modern system - meet each other.

This regional scenario gives opportunity to examine my hypothesis that we can identify the principle of reciprocity as cross-culturally and trans-socially universal base for any concept of justice, be it in its positive form as recompense or in negative terms as retribution and retaliation, and that the different positions, viewpoints and attitudes individual and collective actors might assume in this regard can be traced back to collective commitments and individual interests that configure the ways in which the reciprocity principle is interpreted and applied, but that even its most biased and bold interpretations can not possibly challenge or alter its universally agreed fundamental validity as normative yardstick of social action.

The mentioned two basic organizational and cultural systems shaping the social landscape in my research area, the Ateker region of the borderlands of Sudan, Ethiopia, Kenya and Uganda, are extremely different in crucial dimensions: in regard to the patterns of production and exchange, of social inclusion and exclusion, internal and external conflict regulation, normative reasoning and behavioural ideals.

The society of the pastoralist majority works, when left alone, without division of labour along professional lines, without hereditary positions or permanent political offices. Traditionally, the internal affairs of these communities are peacefully resolved through collective decision making based on open debate, the consensus principle and commonly accepted norms and beliefs tied to ethnic identity and gerontocratic authority, while external conflict is dealt with either in bilateral negotiations of the involved parties or through organized collective violence.

Increasing attempts of national governments to gain control over the persistent inter-ethnic violence of their pastoralist populations, or of international and local NGOs to contain their violent conflicts by mediation, as well as the joint efforts to 'modernise' them and "eradicate" their perceived poverty, produce so far rather mixed and ambiguous results. My research tries to explore the roots of these continuous failures that mark the relationship of those two worlds since their first contacts more than a century ago. It tries to locate their logical base in the contrasting ideals, patterns, and dynamics that configure collective action in these two long coexisting yet persistently distinct systems.

At the first level of my research, I am outlining the structure of the Ateker region as cognitive landscape of social distinction and historical arena of interaction of social units of different type, led by economic and political interests determined by organisational structure and momentary situation. This dynamic structure explains past and present patterns of claims and conflicts over resources, of accumulation and redistribution, of cooperation and solidarity.

On the second level, these findings are related to the landscape of multiple and contradicting discourses accompanying action and institutionalised practice, and especially to their normative elements that can help identifying different ethical concepts which, on their side, inform individual action and collective practice alike.

The third level frames the results into a comparative context where the universality of the reciprocity principle can be traced through the socially determined difference in norms and praxis of interaction and where analysis can justify it to venture to conclusions and practical recommendations.

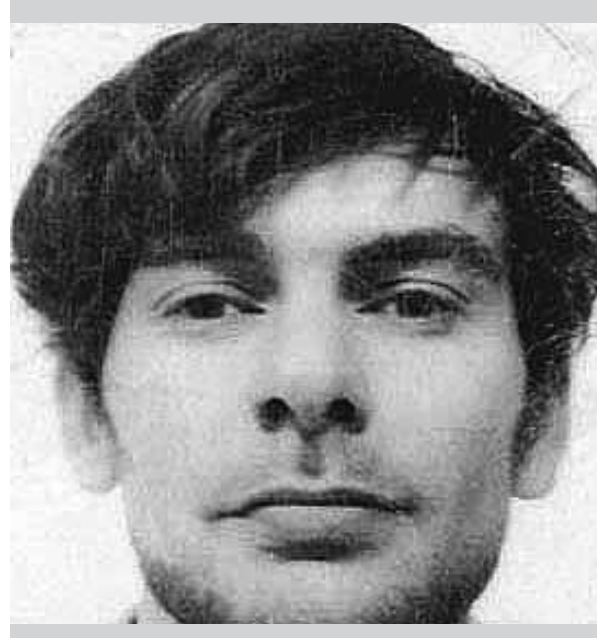

Mr. Immo Eulenberger is a German citizen. In May 2010, he was admitted to the IMPRS REMEP at the MPI for Social Anthropology at the age of 27. Immo obtained a Staatsexamen in History and Philosophy/Ethics from the University of Leipzig, Germany. He is funded by the MPI for Social Anthropology, Department 1. The conclusion of his doctoral thesis is expected for April 2013. Immo is enrolled at the University Halle-Wittenberg. Prof. Dr. Günther Schlee is his supervisor.

Immo is doing fieldwork in Kenya from April 2011 -April 2012.

Publications (selection):

- Eulenberger, Immo: Ogun - Die Gewalt in Person. In: Lioba Rossbach de Olmos / Heike Drotbohm (eds.), Kontrapunkte. Theoretische Transitionen und empirischer Transfer in der Afroamerikaforschung. Marburg 2009: Curupira.

- Eulenberger, Immo (with H. Longole): Karamoja: The Impact of Climate Change. Moroto 2008a: CMDRR.

- Eulenberger, Immo (with Nawal Kamil): Pastoral Nomad Theatre. Nairobi 2008b: VSF-Germany.

- Eulenberger, Immo: Die Macht der Schönheit - mythische Ästhetik und Moderne. In: Bernhard Streck / Mark Münzel (eds.), Ästhetik und Religion, Marburg 2007: Curupira.

- Eulenberger, Immo: Afrokubanische Religion als Alltagspraxis. In: Quetzal N³5, 2004. 


\section{Kiyomi von Frankenberg \\ Consensual Resolution of Conflicts}

Ms. Kiyomi v. Frankenberg is a German citizen. In May 2008, she was admitted to the IMPRS REMEP at the MPI for Foreign and International Criminal Law at the age of 25. Kiyomi obtained a First State Examination in Law graduating from the University of Cologne in 2007. She was funded by the Max Planck Society. The conferral of her doctoral degree and title from the faculty of law of Freiburg University is expected for the summer term 2012. Prof. Dr. Roland Hefendehl and Prof. Dr. Hans-Jörg Albrecht were her supervisors.

She organized a colloquium on plea-bargaining "Konsens als Regel - Was gilt in Mauschelhausen? 1 Jahr Absprachegesetz" at the MPI for Foreign and International Criminal Law in Freiburg on Oct. 15, 2010
The core of this study is concerned with a network analysis of the communication processes involved in plea bargaining in business criminal proceedings. The analysis seeks to reveal structural principles and a normative groundwork for consensual negotiations, as current legal practice seems unable to cope with the specific difficulties associated with the use of plea bargaining in business criminal law. While theoretical questions evolving from penal practice have been intensely debated, little empirical research on plea bargaining in German criminal proceedings exists. However, although plea bargaining is criticized for occurring outside the terms of the Code of Criminal Procedure, it would be of interest to learn more about where its normative groundwork originates. As such, a main aim of the study is to provide an insight into the precise course of plea bargaining negotiations in order to reveal their underlying normative order and preconditions. The analysis focuses on the structure of social exchange and the principle of reciprocity as a means for consensual negotiations. It is argued that mutual exchange can overcome the risks of cooperation and therefore enable conflicting parties to find a toehold for consensual negotiations. A further aspect of this study is to question in how far the consensual elements in plea bargaining contribute to the development of the criminal procedure system with regard to the challenges of white-collar crime.
Publication:

- von Frankenberg, Kiyomi: Konsens als Regel - Was gilt in Mauschelhausen? Ein Jahr Absprache-Gesetz, Monatsschrift für Kriminologie und Strafrechtsreform vol. 94 (2011) issue 3, pp. 228-235. 


\title{
The Use of Human Rights Law in International Criminal Justice
}

\author{
Implementing a Human Rights Approach in International Criminal Law
}

This research project explores the influence of human rights law in the development and practical application of international criminal law. The relationship between international criminal law and human rights law has not yet been conclusively established. On the one hand, international criminal courts and tribunals require well-defined crimes in order to uphold the principle of nulla poena/nullum crimen sine lege. On the other hand, practitioners in this relatively recent discipline have to resort to outside areas in order to fill gaps and interpret the definitions of crimes established by the respective statutes. The acts punishable under international criminal law are often clearly influenced by the requirements set out in human rights treaties. The Rome Statute of the International Criminal Court provides several compelling examples of this in the so-called "treaty crimes"crimes which were enshrined in international human rights treaties although their customary nature was not established beyond doubt.

Apart from generally examining the inter-relationship between human rights law and international criminal law (Part I) and creating an inventory of the use of human rights law in the practical application of substantive international criminal law (Part II), the research project primarily aims to point out areas in which synergies between international criminal law and human rights law exist. It explores the views of practitioners, in particular of judges at the International Criminal Court, towards the use of human rights law in their area of expertise and demonstrates how human rights law can be used in order to strengthen the weight of legal arguments in international criminal law (Part III).

Bassiouni identifies five different stages of emergence and development of human rights as a logical progress from the shaping of shared values, the emergence of non-binding commitments with respect to them and the elaboration

Publications:

- Gebhard, Julia: (with P. Macalister-Smith) Western European Union (WEU); Apartheid; Militias; (with Sh. Rosenne) Conferences on the Law of the Sea; (with D. Trimiño) Reproductive Rights, International Regulation. In: Wolfrum, R. (ed.): Max Planck Encyclopedia of Public International Law. Oxford University Press, Oxford 2011 [online edition; printed edition: to be published 2012]. of specific normative prescriptions towards enforcement. As the fifth and final stage, he identifies the penalization of violations of these shared values. According to Bassiouni, international criminal proscriptions are the final model of enforcing internationally protected human rights.

However, even though human rights law and international criminal law might be described as "two sides of the same coin" there are crucial structural differences between the two areas, one establishes a penal regime based on individual criminal responsibility, the other prescribes a catalogue of rights whose principal respondent is the State.

Following on from these considerations, the research project examines the practical influence of human rights in the jurisprudence of international criminal courts and tribunals. The underlying research question is what role human rights law plays in the development and practical application of international criminal law. The project scrutinizes the extent of direct "use" of human rights law, either mandatory as customary international law or optional as "interpretational guidance" by the respective courts and tribunals, and looks into how the structural differences between the two regimes are accounted for in this context. Additionally, the influence which the idea of human rights protection generally had and still has on the development of international criminal law is examined. Specifically, the areas which are analyzed in this project are minority rights law, women's and children's rights and gender issues as well as the prohibition of torture. In relation to these, the project examines if and how the influence of human rights law is mirrored in crimes punishable under substantive international criminal law. The project focuses on the Rome Statute and the judgments and decisions of the International Criminal Court, but it also considers the jurisprudence of the ad hoc and "hybrid" courts where appropriate.

- Gebhard, Julia: Crimes against Minorities and the Reflection thereof in International Criminal Law. In: Armborst, A., Jensen, D. (Eds.): Retaliation, Mediation and Punishment5. edition iuscrim, forschung aktuell - research in brief, no. 42. Freiburg i. Br. 2010, p. 28-34.

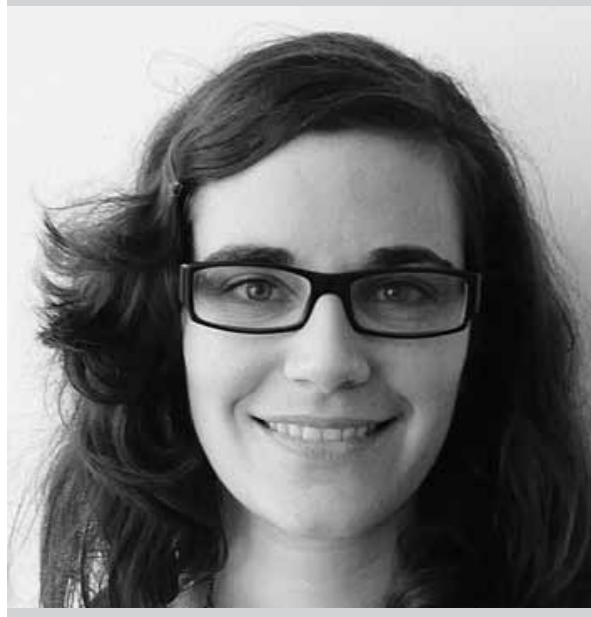

Ms. Julia Gebhard is a German citizen. In August 2008, she was admitted to the IMPRS REMEP at the MPI for Comparative Public Law and International Law at the age of 27. Julia passed the First State Examination at Trier University, Germany in 2006, and obtained an LL.M. degree in 2008 from Lund University, Sweden. She has been a research fellow at the MPI for Comparative Public Law and International Law. The conclusion of her doctoral thesis is expected for July 2012. Julia is enrolled at Hamburg University's faculty of law. Prof. Dr. Rüdiger Wolfrum is her supervisor.

Since June 2011, Julia has been working at the International Criminal Court in The Hague, Netherlands. She is a Legal Assistant at the Investigation Division of the Office of the Prosecutor. 


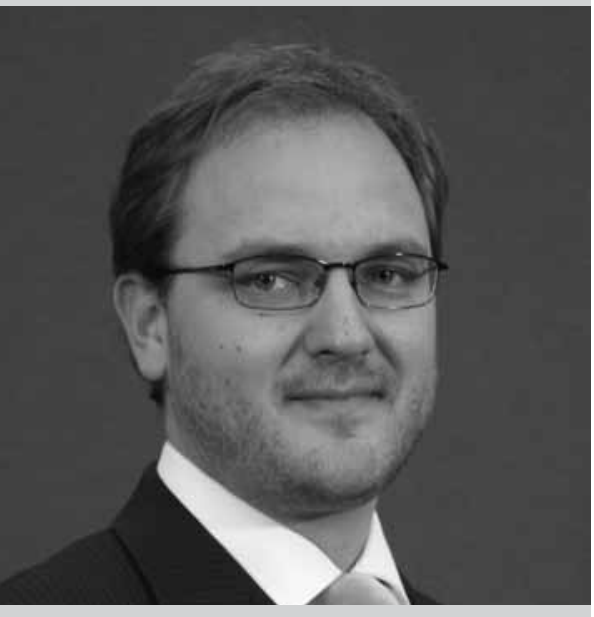

Mr. Csaba Györy is a Hungarian citizen. In July 2009, he was admitted to the IMPRS REMEP at the MPI for Foreign and International Criminal Law at the age of 29. Csaba obtained a J.D. degree from ELTE University of Budapest, Hungary in 2005. He is funded by the Max Planck Institute for Foreign and International Criminal Law. The conclusion of his doctoral thesis is expected for June 2012. Csaba is enrolled at the Faculty of Law at Freiburg University. Prof. Dr. Roland Hefendehl and Prof. Dr. Hans-Jörg Albrecht are his supervisors.

Publications (selection):

- Györy, Csaba: Bevezetés a Kriminológiába. Budapest, 325 p., 2012 (forthcoming).

- Györy, Csaba: Eröszakos devianciák. In: Aáry-Tamás Lajos, Joshua Aronson (eds.): Iskolai veszélyek. Budapest, Complex Kiadó, 2010.

- Györy, Csabay / Orsolya Bolyki, Klára Kerezsi, Katalin Parti, Eszter Sárik: Hungary. In: Josine Junger-Tas / Ineke HaenMarshall, Dirk Enzmann, Martin Killias, Majone Steketee, Beata Gruszczynska (eds.): Juvenile Delinquency in Europe and Beyond. Dordrecht-Heidelberg-LondonNew York, Springer, 2009.

- Györy, Csaba / Klára Kerezsi (ed.), József Kó: Longitudinális kriminológiai vizsgálatok és alkalmazásuk lehetöségei Magyarországon. Budapest, Egészséges Ifjúságért Alapítvány/Budapest Föváros Önkormányzata, 129 p., 2009.

\section{Csaba Györy}

\section{Criminal Law as a Means of Regulation: The Interplay between Economic, Legal, and Political Rationalities in the Prohibition of Insider Trading and its Enforcement}

\section{A Comparative Study}

\section{Subject of Research}

Despite the processes of unification in financial regulation, there are many elements in the structure, organization, and regulation of financial markets that show a remarkable perseverance against unification. These differences appear not only in the "law in the books" (density of regulation; scope of criminalization of the breaches of financial regulation; procedural powers of enforcement entities, etc.), but also in the "law in action" (enforcement intensity; allocation of resources within regulatory and enforcement agencies; exercise of prosecutorial discretion, etc.).

In this research, the focus lies on the scope of criminalization of the breaches of financial regulation, and on the relationship between civil and criminal enforcement. The basic research question is: what accounts for differences in the scope of the criminalization of securities regulation breaches, and for the differences in enforcement intensity?

The hypothesis is that these differences result from the interplay of at least three factors:

1. The political and economic environment of financial regulation as a whole;

2. The status of criminal law and the relationship between civil/administrative and criminal enforcement;

3. Institutional and organizational practices, recruitment processes, attitudes of officials in regulatory authorities and law enforcement agencies.

Insider trading has been selected as a case study. Selecting a set, well-defined and relatively autonomous (in terms of interconnectedness with other parts of securities laws) element of regulation will enable a "vertical cut" through all levels of analysis. As the insider trading prohibition in German law is a legal transplant from the US, comparative research will enable the study to map the learning processes through which regulatory and law enforcement authorities adapt to new elements of securities regulation and criminal law.

\section{Theoretical Framework}

In the analysis of the interconnectedness of financial markets and financial regulation, the framework is based on multiple paradigms in the political economy. It draws on those approaches in international political economy (IPE) that depart from a purely external concept of state power and market power, and theorizes the notion of "structural power" to describe socio-economic, class, and institutional dimensions and sources. In the particular case of a US-German comparison, where certain elements of market structures do seem to show a remarkable persistence despite interventions to "internationalize" them, some aspects of the "varieties of capitalism" paradigm in comparative political economy (CPE) may also prove useful to the analysis.

Political economy approaches, however, display a tendency to ontologize the distinction between markets and institutions, and they focus on formal state institutions and organizations and tend to disregard the social sources of state capacity. They tend to regard regulation as a formalistic entity. It is argued, however, that each legal system has an inner logic and inertia that is partly constituted by is internal dogmatic structure and partly by its application by regulatory authorities, law enforcement agencies, and courts. In this respect, the research project seeks to draw from the system theory approach of legal sociology, especially the work of Gunther Teubner.

\section{Methodology}

The first phase of the research involves the analysis of the development of insider trading regulations and case law in the context of the evolution of financial markets in Germany and the US. In the second phase of the research, interviews will be conducted with acting or former officials at regulatory agencies and prosecution offices, as well as with compliance professionals and traders. 


\section{International Arrest Warrants in ongoing Conflicts - the Legal Framework of Criminal Law Interventions by External Actors}

The Arrest Warrants in the Northern Uganda Case and the Darfur Case at the ICC

The dissertation project focuses on a normative approach to the (regrettably) often termed "justice vs. peace dilemma”, better described as a conflict between the need (or will) to punish perpetrators of international crimes and the need to end hostilities, thus preventing combats and the commission of new crimes. The project aims at establishing normative criteria (with a focus on public international law in general) to resolve the above mentioned conflict where the political framework conditions impede the simultaneous pursuit of criminal prosecution and the implementation of peace agreements. The newly created International Criminal Court (ICC) will be the focus of the dissertation project since in two of the situations - Northern Uganda and Sudan (Darfur) - this conflict occurs, inter alia, due to the ongoing nature of the conflict. The arrest warrants issued against the Ugandan rebel leader Joseph Kony and the sitting president of the Republic of Sudan, Omar Al-Bashir, are the source of contentions in the current political and legal debate. The dissertation aims to assess which international obligations are pertinent to the conflict arising from the issuance of these international arrests warrants. Even a cursory review of relevant sources reveals conflicting obligations and rights. On the one hand, international conventions (like Art. IV of the Genocide Convention) and customary international law (e.g. punishment of crimes against humanity) set out an obligation or at least a right to punish the main perpetrators, while on the other hand, international law (especially the UN Charter, a number of human rights treaties, as well as the concept of "Responsibility to Protect") favour the prevention of future crimes and hostilities.

The primary aim of the dissertation is to evaluate whether international law (either in abstracto or in concreto) favors one of these - in these situations - contradictory legal obligations or rights. Therefore, the dissertation project will focus on the concept of jus cogens and Article 103 UN Charter and will treat the question of the legal relevance of the concept of "Responsibility to Protect" in order to show if there is a hierarchy of norms in international law and if this hierarchy is pertinent to the cases examined in the dissertation. It will also address other aspects of the theory of conflicts of norms.

Based on this analysis, the dissertation proceeds with the procedural consequences of the anticipated assessment that there is no valid claim for primacy of the criminal law approach in international law. For this reason, the dissertation project will address the concrete decisions which were and are to be taken in the cases of Northern Uganda and Sudan (Darfur). It evaluates the possibilities de lege lata of the Office of the Prosecutor and the Pre Trial Chamber of the ICC to take into account the normative indicators when deciding if an arrest warrant should be issued (Art. 57 III (a) of the Rome Statute) or withdrawn, or an investigation opened/closed (Art. 53 II (c), III (a)-(b) of the Rome Statute). It gives an analysis of the possibility of the UN Security Council to act under Article 16 of the Rome Statute or even on the sole basis of Chapter VII of the UN Charter. To conclude, the dissertation will address the legal consequences of the decisions for future national or international criminal proceedings (esp. the doctrine of "abuse of process") and will give a short overview on the feasability of possible compromises.

For this purpose, international conventions, national and international jurisprudence, literature and written media sources will be analyzed. This will be supplemented by an analysis of non-binding international documents and govermental statements in order to explore the content of the relevant customary international law based on a "mordern positivist"-approach.

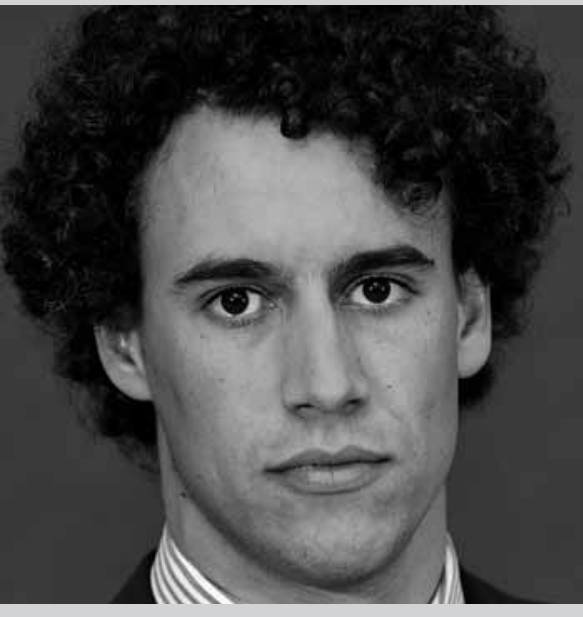

Mr. Mayeul Hiéramente is a French and German citizen. In October 2008, he was admitted to the IMPRS REMEP at the MPI for Foreign and International Criminal Law at the age of 25. Mayeul obtained his First State Examination graduating from the University of Hamburg and the Université Paris XNanterre, France. He was funded by the Max Planck Society. The conferral of his doctoral degree and title from the faculty of law at Freiburg University is expected for February 2012. Prof. Dr. Ulrich Sieber and Prof. Dr. Walter Perron were his supervisors.

Publications (selection):

- Hiéramente, Mayeul: The Myth of "International Crimes": dialectics and international criminal law, in: Göttingen Journal of International Law, 3(2011), 2, S. 551-588.

- Hiéramente, Mayeul: Der Internationale Strafgerichtshof und die Vereinten Nationen: Ein ungeklärtes Verhältnis. In: Vereinte Nationen, 2010, Issue 6, p. 255 - 259.

- Hiéramente, Mayeul: "Die Anklage auf der Anklagebank" oder "Wie die Berufungskammer des IStGH das Lubanga-Verfahren zu retten versucht"BOFAXE4 $\mathrm{Nr}$. 359D, 4.11.2010.

- Hiéramente, Mayeul: Freiheit für mutmaßlichen Kriegsverbrecher Lubanga? "Richter vs. Ankläger" oder "Der IStGH und Probleme mit der Fairness", BOFAXE5 Nr. 354D, 30.8.2010. 


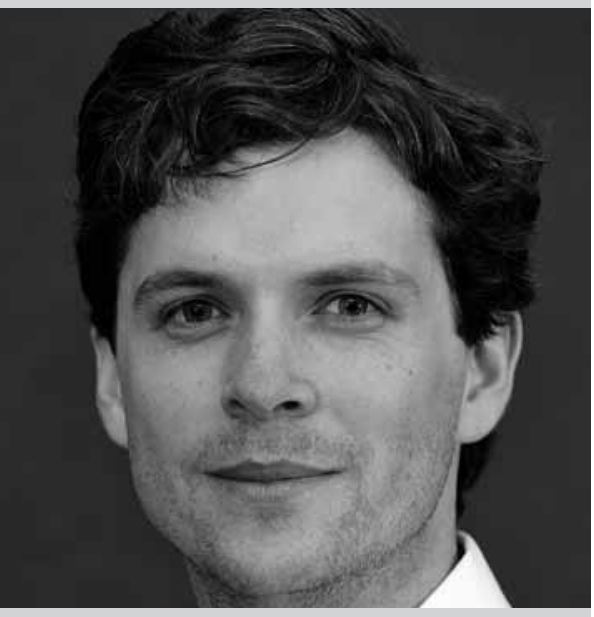

Mr. David Jensen is a U.S. American and Costa Rican citizen. In November 2008, he was admitted to the IMPRS REMEP at the MPI for Foreign and International Criminal Law at the age of 26 . David obtained a LL.B. degree from the University of Costa Rica in 2003 and a LL.M. from the University of Freiburg 2010 . He was funded by the Max Planck Society. David will take the oral exam at the Faculty of Law at Freiburg University in February 2012. Prof. Dr. Hans-Jörg Albrecht and Prof. Dr. Walter Perron are his supervisors. Priv.-Doz. Dr. Dietrich Oberwittler, senior researcher and research group leader at the MPI for Foreign and International Criminal Law is his day-to-day supervisor.

Publication:

- Jensen, David: Naming your enemies. In: Armborst, A., Jensen, D. (eds.): Retaliation, Mediation and Punishment. edition iuscrim, forschung aktuell research in brief, no. 42. Freiburg i. Br. 2010 , p. $50-55$.

\section{David Jensen}

\section{Maras: A Study of Their Origin, International Impact, and the Measures Taken to Fight Them}

The maras, once only an immigrant street gang in Los Angeles, have increasingly gained attention in the media and with the national authorities of the United States, Central America and Canada. The authorities are concerned about the maras: not only are they extremely violent and committed to crime (mainly drug trafficing, extortion and violent crimes), but they have also managed to go a step further to develope a sort of international criminal network with between 70,000 and 500,000 members.

In the mid 1990s, as most of Central America had finally overcome years of civil war, the new democracies faced the consequences of their military era. An unfavourable economic situation, social crises and fragile political stability were some of the problems they had to confront both then and today.

In addition to these problems, in 1996, the Congress of the United States of America passed a law that simplified the deportation of non-citizen delinquents to their country of origin. Around $80 \%$ of the 500,000 deported delinquents came from Latin-American countries namely Jamaica, Honduras, El Salvador, Colombia, Mexico, Guatemala and Dominican Republic. This resulted in a massive deportation of maras gang members to Central America, where they eventually reorganized and continued their criminal activities.

The Latin-American countries, in contrast with the United States, lacked the necessary resources to combat the growing number of gang members (the so-called mareros), thus giving place to their proliferation and losing partial control of some cities to their domain.

As the internal security sunk to levels comparable to the period of the civil wars in many places, the maras-issue became a major subject in political campaigns.
In 2003, the Honduran government modified the penal code to prohibit and punish the mere membership in a gang with between six and twelve years in prison. In addition, as part of Operación Libertad (Operation Liberty) large numbers of military and police units began patrolling the streets and carrying out raids in deprived areas.

Likewise, the government in El Salvador first implemented in 2003 the Plan Mano Dura (Hard Hand Plan), which also provided law enforcement through military and police deployment and raids and a more severe penal law against gangs, and then, in 2004, the Plan Súper Mano Dura (Super Hard Hand Plan), which emphasized the importance of prevention, rehabilitation and social reintegration, but also intensified the persecution of the maras.

The Guatemalan government has not yet implemented an anti-maras law, it did, however, make the fight against the maras one of its priorities. Along with Plan Escoba (Sweep Plan), which resulted in mass arrests, complementary preventive measures were taken e.g. the program Desafio 100 (Challenge 100), which aimed to reintegrate former gang members.

This research is devoted to the analysis of the mara phenomenon, of how street gangs can evolve into international crime organizations, and of the measures taken against the maras, which are mainly those of severe punishment and repression. In order to perform this analysis, the investigation will firstly focus on the origins, structure and activities of the maras with the intention of understanding the causal nature of the problem. It will then study the measures that were implemented against the maras at the national and international level and their consequences with respect to the justice system, human rights and the maras. In doing so, it will help understand the role punishment plays in the modern world. 


\section{The Judicial Interpretation of Honour Killings in Germany}

In recent years, so-called 'honour killings' have received increased attention and sparked controversial public debates in Germany and numerous other countries, including Great Britain, Canada, the Netherlands, and Sweden. One of the points at issue concerns how criminal courts should react to the phenomenon of honour killings. Especially in the U.S., Great Britain, Canada and other common law countries, there has been a debate on the use of a 'cultural defence' to diminish or exclude criminal liability in cases of honour killings, as well as in other cases which potentially result from the cultural background of the offender (e.g., female genital mutilation). A similar discussion occurred in Germany during the 1980s and has once again been rekindled in recent years.

Despite the rise in public attention, only a few academic publications have thus far focused on the issue of criminal punishment of honour killings in Germany. These studies have approached the topic from a theoretical perspective, mostly including a discussion of the case-law of the Federal Supreme Court of Germany (Bundesgerichtshof or BGH) on honour killings. Pursuant to the current judiciary of the BGH, the cultural setting of the perpetrator can only lead to a more lenient sentence under exceptional circumstances, especially if the perpetrator was unable to disengage from his cultural ties. Generally, the offender is to be convicted of murder for base motives, which implies imprisonment for life. As the judges of the BGH did not however elaborate on the specific premises of the exceptional circumstances, their reasoning leaves a notable margin for interpretation in the German regional courts, which have jurisdiction in the first instance over indictable offences, including murder and manslaughter. Due to this fact, and because the decisions of the BGH are not binding on lower courts, the question arises as to how the judges of the regional courts should handle these cases, whether they decide to convict the offend- ers of murder or manslaughter, and whether they consider the cultural background of the offender a mitigating or rather an aggravating circumstance. To date, no empirical research on the rulings of the German regional courts regarding the punishment of honour killings has been done. The $\mathrm{PhD}$ project intends to close this research gap and, therefore, aims to determine how the German regional courts deal with the differing moral concepts and values of the offenders and, furthermore, ascertain which factors are relevant for the process of decisionmaking and sentencing in honour killing cases.

To this end, an extensive quantitative and qualitative analysis of the regional courts' judgments on honour-related cases of intentional homicide (including attempts) in the period between 1996 and 2005 has been conducted. The results of this analysis are partially unexpected: In $42 \%$ of the cases, a review of the honour motive as a base motivation was not performed, which raises a number of questions in light of the BGH's landmark decision. Moreover, it appears that the regional courts broadly interpreted the exception laid down by the BGH since only $24 \%$ of the offenders were convicted of murder for honour motives. In addition, for 23 perpetrators $(33 \%)$ the honour motive led to a mitigated sentence; in not a single case did the judges consider the honour motive to be an aggravating circumstance. In summary, it would appear that the judgments in the cases studied were more lenient than was to be expected under the legal precedent set by the BGH.

A second research aim of the project is to examine whether the sentencing of German regional courts in honour-related homicides differs from the sentencing in other cases of intentional homicide. A sample of intimate partner killings occurring in the same timeframe is currently being analysed; subsequently, comparisons between both samples will be drawn.

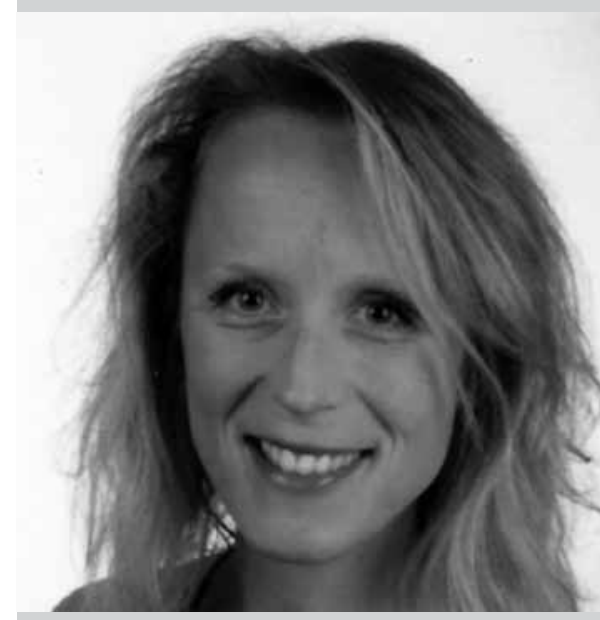

Ms. Julia Kasselt is a German citizen. In May 2009, she was admitted to the IMPRS REMEP at the MPI for Foreign and International Criminal Law at the age of 28. Julia passed the First State Examination in Law at Humboldt University, Berlin in 2006 and obtained a M.A. degree in International Criminology from Hamburg University in 2008. She is funded by the Max Planck Institute for Foreign and International Criminal Law. The conclusion of her doctoral thesis is expected for December 2012. Julia is enrolled at the Faculty of Law at Freiburg University. Prof. Dr. Hans-Jörg Albrecht and Prof. Dr. Walter Perron are her supervisors. Priv.-Doz. Dr. Dietrich Oberwittler, senior researcher and research group leader at the MPI for Foreign and International Criminal Law is her day-to-day supervisor.

Publications:

- Oberwittler, Dietrich / Kasselt, Julia: 'Honor' Killings. In: Gartner, Rosemary / McCarthy, Bill (eds.): The Oxford Handbook on Gender, Sex, and Crime. Oxford, Oxford University Press, forthcoming 2012.

- Oberwittler, Dietrich / Kasselt, Julia: Ehrenmorde in Deutschland. 1996-2005. Eine Untersuchung auf der Basis von Prozessakten. Köln, Wolters Kluwer Deutschland, 2011. 


\section{At the Margins of the South African Lowveld}

The Dynamics of Disputing Processes in Plural Legal Orders

In exploring the social working of law in situations of legal pluralism and revitalized tradition, this $\mathrm{PhD}$ project analyzes the dynamics of dispute management in processes of social ordering.

The PhD is based on ethnographic fieldwork was carried out in the South African lowveld and northern Swaziland at different intervals from 2007 to 2011 . The aim of the study is to address the fundamental questions of the Research School concerning how people refer to retaliation, mediation, and punishment to construct, negotiate, and maintain social order in siSwati-speaking eMjindini/Barberton. It specifically explores how and under what conditions a 'customary' order is produced in relation to other prevailing political, legal, and religious concepts. How does this manifest itself in everyday life and particularly in disputes? What are its mechanisms and ramifications in both social and legal terms?

To answer these questions, particular focus is laid on the production of locality as a social process. It is argued that traditional authorities claim legitimacy and power over land and people by constructing a transborder locality referring to both territoriality and the expression of eMjindini and its people as subjects of the Swazi monarchy in historical terms. In this way, the fluidity of boundaries of authority between rural and urban areas and across national borders is discussed.

Moreover, by connecting locally significant fields of contention and social interaction, the project analyzes the ways in which disputing parties inform and shape notions of 'customary' order in everyday practices and particularly in dispute processes. The ethnographic examples dealt with range from witchcraft accusations and magical retaliation to the negotiation and mediation of intimate relationships as encountered in different disputing arenas from courts through to the consultation rooms of traditional healers.

In this way, the study seeks to provide an original perspective on processes of dispute as related to the production of normativity and order, i.e., of how people (should) live together and organize social life under plural legal constellations.

\section{Publications:}

- Lenart, Severin / Handl, Stephan / Rest, Matthäus Something we could never have: Die südafrikanische Landreform und ihre Auswirkungen mit Beispielen aus dem Weinbau. In: Zips, Werner (ed.): To BEE or not to be? Black Economic Empowerment im neuen Südafrika am Beispiel der Weinindustrie. Vienna, LIT-Verlag, 2008a, p. $233-268$.

- Lenart, Severin / Schweitzer, Erwin: Der Drahtseilakt. Die südafrikanische Landreform zwischen gesellschaftlicher Transformation und kommerzieller Agrarwirtschaft. In: Südwind - Magazin für internationale Politik, Kultur und Entwicklung [Vienna], March 2008b, Issue/Volume 3, p. $18-19$.

- Lenart, Severin: Mawubuye umhlabawethu! - Lasst uns unser Land zurückholen! Eine Analyse der südafrikanischen Landreform. In: Progress. Magazin der Österreichischen HochschülerInnenschaft [Vienna], 2007, Issue/ Volume 6, p. 25

- Lenart, Severin / Schweitzer, Erwin: Weißer Wein in schwarzen Flaschen? Black Economic Empowerment in der Weinerzeugung Südafrikas. In: INDABA - Das SADOCC-Magazin für das südliche Afrika [Vienna], 2006, Issue/Volume 52, p. 3 - 8.

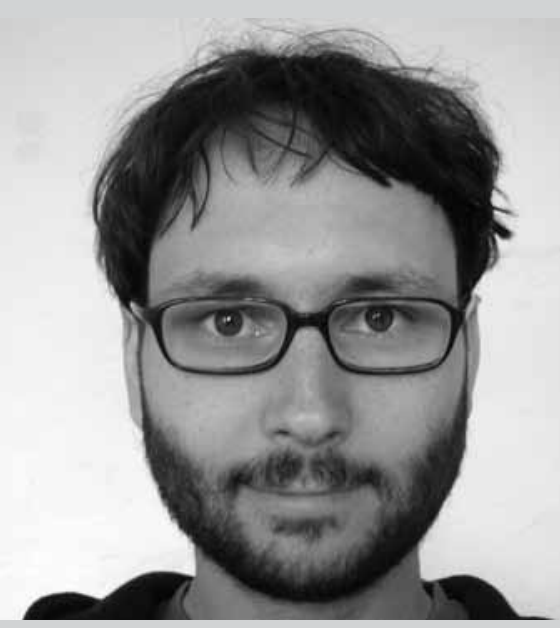

Mr. Severin Lenart is an Austrian citizen. In April 2008, he was admitted to the IMPRS REMEP at the MPI for Social Anthropology at the age of 27. Severin obtained an MPhil degree in Social and Cultural Anthropology from Vienna University, Austria, in 2007. He is funded by the Max Planck Society. The conclusion of his doctoral thesis is expected for April 2012. Severin is enrolled at the Faculty of Philosophy at the University Halle-Wittenberg. Prof. Dr. Keebet v. BendaBeckmann and Prof. Dr. Richard Rottenburg are his supervisors.

Severin did his fieldwork in South Africa (Mpumalanga) and Swaziland (Hhohho) from October 2008 until October 2009. From September 2011 until October 2011 he did field research in South Africa (Mpumalanga). 


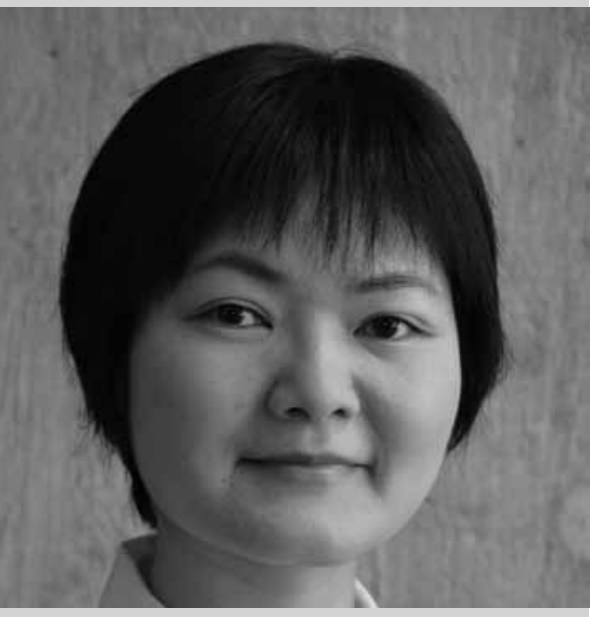

Ms. Meng-Chi Lien is a Taiwanese citizen. In April 2008, she was admitted to the IMPRS REMEP at the MPI for Foreign and International Criminal Law at the age of 28. Meng-Chi obtained a LL.B. degree from National Taiwan University, Taipei, and LL.M. degree from the Division of Criminal Law at National Taiwan University. She is funded by the Max Planck Society. The conclusion of her doctoral thesis is expected for January 2012. Meng-Chi is enrolled at the Faculty of Law at Freiburg University. Prof. Dr. Hans-Jörg Albrecht and Prof. Dr. Roland Hefendehl are her supervisors. Dr. Michael Kilchling is her dayto-day supervisor.

\section{Publication:}

- Lien, Meng-Chi: Mediators in Criminal Matters. In: Armborst, A., Jensen, D. (eds.): Retaliation, Mediation and Punishment. edition iuscrim, forschung aktuell research in brief, no. 42. Freiburg i. Br., 2010, p. 43 - 49.

Meng-Chi Lien

\title{
Victim-Offender Mediation and the Role of the Public Prosecutor
}

\author{
A Comparison of Germany, Taiwan, and China
}

In Germany, the implementation and legislation of Victim-Offender Mediation (VOM) for adults followed the pattern of juvenile justice. Two significant regulations in the Criminal Procedural Code are sections 153 and 153a, which entrust public prosecutors with discretionary power to dismiss a case or postpone indictments with or without conditions. Furthermore, in 1999, sections 155a and 155b were introduced to promote the application of VOM in criminal procedures. Today, VOM has undoubtedly become an essential part of the German criminal justice system.

Unlike in Germany, where mediation is a relatively new concept, in the Chinese culture mediation is the traditional means for dealing with interpersonal conflicts. Therefore, Taiwan and China, in spite of different ideologies, have developed similar systems of mediation within administrative units at lower levels. The "Mediation Committee" (Tiaojie weiyuanhui) in Taiwan and the "People's Mediation Committee" (Renmin tiaojie weiyuanhui) in China have successfully settled many civil cases out of court for several decades.

In respect of criminal procedure, Taiwanese criminal procedure law does not provide any rule directly concerning mediation. In China, mediation can only be applied in the case of private prosecutions and not (until now) in the case of public prosecutions $(\$ 172$ Chinese Criminal Procedure Law). In recent years, the worldwide movement of Restorative Justice attracted attention both in Taiwan and China, where the response has been positive. In contrast to the German prosecutors, the Chinese prosecutors display great interest in applying mediation in criminal matters (MIC). They have even been implementing MIC on a trial basis in the case of public prosecutions in many local areas and have gained satisfying results. In Taiwan, the Ministry of Justice developed a pilot project of VOM with eight public prosecutor's offices, aiming at testing public acceptance and exploring the needs and/or concerns of participants. In general, this project has been welcomed by the public prosecutors.

The research results show that despite the common tradition of mediation and the familiarity with its advantages as a dispute resolution tool, the implementation of MIC displays very different patterns in Taiwan and China. In Taiwan, the seeming "legal restrictions" do not restrict the application of MIC from the view of the public prosecutors. They are unanimous that mediation is an instrument for dealing with civil matters. If there are civil disputes involved in a criminal case, the civil matters can without doubt be dealt with by mediation and the result of agreements arising out of mediation will be incorporated into judicial decisions. Given this background, the introduction of VOM as a "new" instrument is facing doubt concerning its necessity and practical benefits. On the contrary, mediation in China is legally not allowed to be used in the case of public prosecutions and this is obeyed in practice. That said, some Chinese public prosecutors now have the possibility to try MIC to deal with misdemeanors, especially less severe cases. The introduction or revival of MIC does cause debates on its integration in the current criminal system. For both Taiwan and China, the theoretical discussions and experience of VOM in Germany provide a good example of how to integrate a restorative justice program in a civil law system. 


\title{
Compliance and Money Laundering Control by Financial Institutions in China
}

\author{
Self Control, Administrative Control, and Penal Control
}

\section{Topic and Goal}

Since a series of corporate scandals such as the cases of Enron, Siemens and WorldCom occurred, the academic field has been mired in debates about how to control economic crime. Strategies of compliance promotion and crime/ deviance prevention have been widely studied, ranging from traditional formal control approaches such as instrument of penal control to informal approaches such as instruments of corporate governance (self control).

This study seeks to delineate the current economic crime/deviant control mechanisms in China. Three popular control instruments with escalating severity - self control, administrative control, and penal control - will be studied. The aim of this study is to explore how these three instruments are regulated in China, their advantages and limitations, how they are linked to one another, the challenges they seek to confront, and the type of solutions that are required to a achieve a smooth functioning, comprehensive approach.

\section{Research Design}

Compliance of financial institutions and money laundering control in China will be studied as a case in point. Apart from a literature review and an introduction of research design (Part 1), this study analyzes three control approaches, i.e. self control (Part 2), administrative control (Part 3), penal control (Part 4), and then further studies their linkages (Part 5).

Besides the theoretical framework based on John Braithwaite's responsive regulation and Julia Black's risk-based responsive regulation, this study samples empirical material from official documents (annual reports of the People's Bank of China, the Supreme People's Procuratorate and the Supreme People's Court), relevant news report and interviews with professional staff.
Hypotheses

Given that each of the three instruments have both advantages and limitations, a networking approach (comprehensive approach) is essential to achieve sound compliance among financial institutions. Self control is the key element in the networking approach, considering that self regulation is prevention oriented with internal control systems and internal "police" (compliance officers) that facilitate the earlier discovery of misconduct. A key element to achieve efficient enforcement of these instruments is creative linkage among them. First, control instruments with different severity should be allowed to shift in response according to the regulatee's behavior and the resulting risks. Second, incentive devices are not necessarily limited in informal control approaches, but should also be applied to formal control approaches, even to punitive control approaches. Likewise, punitive devices should be involved in informal control approaches.

Added value to the overall REMEP research program

This study is based on the assumption that the applicability of penal control (primarily punishment) to white collar crime control is seriously limited; it also assumes that an effective regulation presupposes the involvement of other control approaches, e.g., self control, and the proactive linkage of various approaches. Therefore, in line with the research program of the IMPRS REMEP, it addresses general concerns on the limits of penal control in the maintenance of social and economic order and suggests a comprehensive approach.

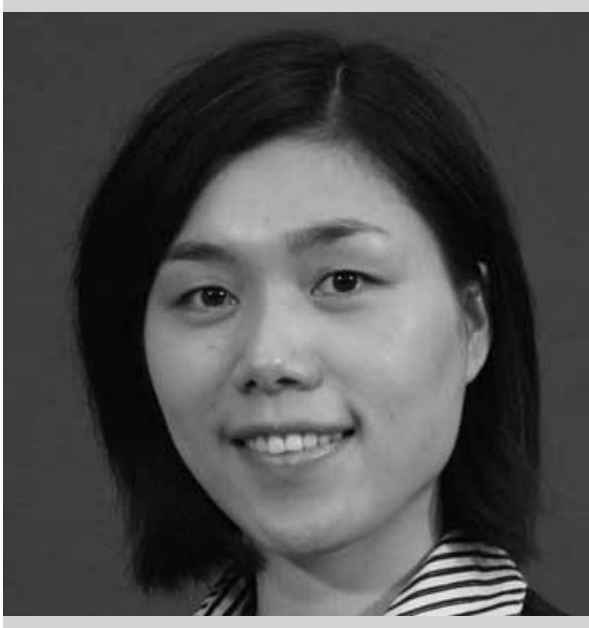

Ms. Jing-Lin is a Chinese citizen. In September 2009, she was admitted to the IMPRS REMEP at the MPI for Foreign and International Criminal Law at the age of 27. Jing obtained a LL.B degree from China University of Political Science and Law in Beijing, China, in 2005, and a LL.M degree from the Chinese - German Institute for Legal Studies at CUPL in Beijing, in 2009. She also obtained a LL.M degree with focus on Criminal Law and Criminology in 2008 from Freiburg University. She receives a scholarship by the Chinese Republic. The conclusion of her doctoral thesis is expected for August 2012. Jing is enrolled at the faculty of Law at Freiburg University. Prof. Dr. Hans-Jörg Albrecht and Prof. Dr. Roland Hefendehl are her supervisors. Dr. Michael Kilchling is her dayto-day supervisor.

Publications (selection):

- Lin, Jing: An Approach of "Referism": a Comparative Study on Diversion in Juvenile Justice between China and Germany. In: Peking University International and Comparative Law Review, 2010, Issue/Volume 11/8, p. $17-60$.

- Lin, Jing: Study on European Human Rights Law's Influence on the European Integration Process. In: Mi, Jian (ed.): The Role of the European Law in the European Integration (ouzhoufa zai ouzhou yitihua jincheng zhong de zuoyong). Beijing, Law Press (Falue), 2009, p. 52 - 75. 


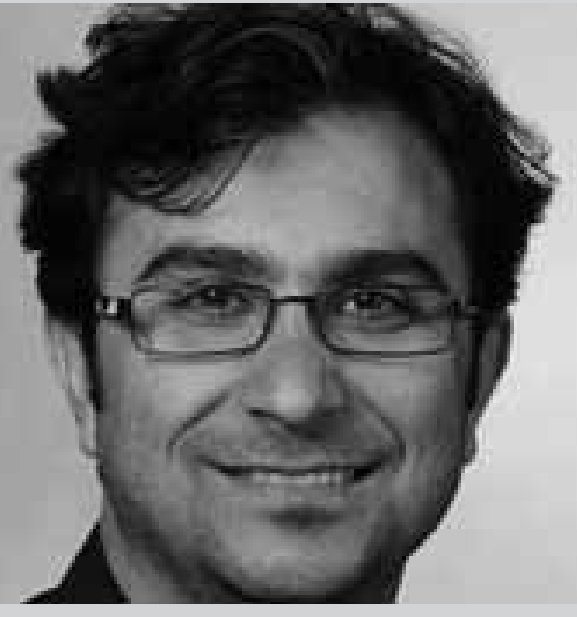

Mr. Fazil Moradi is a Swedish citizen. In July 2011 , he was admitted to the IMPRS REMEP at the MPI for Social Anthropology at the age of 32. Fazil obtained a B.Soc.Sc. degree in Sociology, International Relations and Gender Studies at the University of Uppsala and University of Gothenburg, Sweden, in 2010. In 2011 he obtained a M.Soc. Sc. degree in Sociology, Middle East Studies, and Philosophy at the University of Uppsala. He is funded by the Max Planck Society. The conclusion of his doctoral thesis is expected for mid 2014. Fazil is enrolled at the University Halle-Wittenberg. Prof. Dr. Richard Rottenburg is his supervisor.

He will conduct his fieldwork from July 2012 onwards in Iraq.

Publications (selection):

- Moradi, Fazil: COLOR-LINE The Petrifaction of Racialization and Alterity at the University of Stellenbosch. In: Journal of Higher Education in Africa, 2011 (forthcoming).

- Moradi, Fazil: COLOR-LINE: Minority Students' Encounters at the University of Stellenbosch. MA Thesis, Department of Sociology, Uppsala University 2010.

- Moradi, Fazil: The SubAlternized Other: A Qualitative Study of Non-European Immigrants in Sweden - From a Postcolonial Perspective. BA Thesis, Department of Sociology, Uppsala University 2010.

\title{
Fazil Moradi
}

\section{Negotiating Social Justice in Post-Ba'ath Iraq}

\author{
A Recognition and Reparation Campaign against the Iraqi State
}

The systematic nature of political and structural violence committed by the Ba'ath Party under Saddam Hussein's leadership against the Iraqi people, in violation of international human rights law and domestic criminal law, suggests that an assessment of post-Ba'ath social justice claims is needed. Among the betterknown crimes committed by the regime against its own civilian population is the Al-Anfāl ("Spoils of war" in Arabic) campaign in 1987-8. The pursuit of recognition and reparation due to this campaign, nationally and internationally been recognized as "Kurdish genocide," has in recent years become a matter of concern for certain governmental and non-governmental actors.

The current study directs attention to these once-denied human rights violations as they are translated into a recognition and reparation claim (i.e., restitution, damages compensation, rehabilitation, and guarantee of non-repetition). In doing so, it aims to contribute to the studies of reparation claims and international human rights discourses on law and social movements that stress the importance of not only international human rights law but morality and political accountability. Claims of reparation, which highlight the idea of coming to terms with past violations, have been and increasingly continue to be an important field of study for scholars from various disciplines studying post-conflict societies and social change. Post-Ba'ath Iraq has witnessed major shifts and transformations in the social, political, and legal spheres. The swift creation of the "Iraqi Special Tribunal" to try leading figures of the Ba'ath Party for "war crimes, crimes against humanity, and genocide," and exact retributive justice has come to underline the notion of "justice being seen to be done." Such processes have opened up the possibility for Al-Anfāl survivors to release themselves from an imposed condition of victimization that produced and re-produced them as submissive subjects. It is against this background, which transcends Hammurabi's code of retaliation "an eye for an eye," that the involved Al-Anfāl actors confront the politics of reparation.

The recognition and reparation campaign that seeks to obtain social justice for Al-Anfāl survivors offers a valuable study to help unravel the challenges embedded in the retaliatory measures against the Iraqi State. The retaliatory measures of the campaign lie in its emphasis on the rights of "genocide" survivors that reveal the culpability of the Iraqi State. The challenges are also coupled with efforts to apply international human rights law to a domestic claim. Thus, the central aim of this project explores the way in which civic and political actors have exploited existing domestic legal avenues to translate international human rights norms into social justice for Al-Anfāl survivors. In addition, in their efforts to obtain recognition and reparations, actors have challenged government policy and sought legal reforms on contemporary social justice issues. Therefore the study focuses on the implications of these claims - especially their translation and the negotiations of the Iraqi State - as these enable governmental accountability and responsibility to be measured. In this regard, the translation is understood as a process of moving human rights discourses from the global to the local, in order to make the Iraqi State and the Al-Anfāl survivors legitimate subjects to international human rights instruments. 


\section{Youth and Violence in Brazil: The Reality behind the Rates}

In 2010 the government of Rio de Janeiro city began an ambitious mission: to expel the drug gangs from the "Favelas" in order to restore order and control in these areas by installing Pacification Police Units (UPPs).

Studies carried out by the Sangari Institute to analyze cases of homicide registered in the Brazilian Information System of Mortality, show two important conclusions which may help to better understand violence in Brazil. First, young people play an important role in the increase of violence, and second, violence is migrating to small and medium cities in Brazil. In the past, violence leading to death among young people was related to large, overcrowded, slum areas of cities; today it has become one of the main problems of small towns.

According to the Sangari Institute, homicide rates among youths between 15 and 24 years old have almost doubled. In 1980 the rate was 30.0 per 100,000 inhabitants; in 2007 it had grown to 50.1. According to the World Health Organization, Brazil now has the 6th highest youth homicide rate in the world.

The reasons behind this homicide rate are many: for example, youths are murdered due to confrontations between police and drug dealers, or killed fighting against security forces; war between gangs in order to gain new drug dealing territory also plays a role, as do fights against rival "facção" who encroach on occupied territory; being indebted to drug dealers is also as problem, as is the fact that some youths use violence as a way to steal from people or as a retaliatory measure against inequality. Furthermore, in big cities like São Paulo and Rio de Janeiro, there is a new group called the "Milícia”, usually composed of corrupt police officers or former officers who extort money from drug dealers or demand money to protect them and ordinary citizens living in dangerous areas. If they do not pay for this protection, they may be murdered as a form of punishment. In any case, youths are the largest group of victims in this context. Some of them have chosen or were motivated to become criminals; others are merely victims of violence.

Some cities are experiencing rapid industrial growth, which in turn is attracting an influx of workers, including a substantial amount of young people. The population increase also attracts drug dealers. As the number of would-be workers arriving in the cities often exceeds the available work opportunities, a vast number of unemployed persons are vulnerable to be used to traffic drugs. Usually recruits enter the drugs business at the lowest level and over time become more involved; this could be because they become dependent on drugs or because they wish to be more powerful and wealthy. One way they can achieve this power is by using violence as a tool.

The analysis of the particularities of violence, especially in the perception of youths, and the role that violence plays for them, i.e., in the context of gangs, is the central subject of this research. Furthermore, it is important to investigate in which situation(s) violence is considered as an instrument for retaliation and punishment and how the possibility of killing or being killed motivates or demotivates them to carry on their criminal careers. Another point of this research is to discover how big cities have managed to control violent areas and why other cities are becoming more violent. The fieldwork for this research will concentrate on Rio de Janeiro city and Maceió (153rd and 1st positions on the Sangari Institute's ranking respectively). A further step will analyze the relationships between state, law, and youth violence. The research methodology is based on observations and the collection of information during interviews with youths, parents, community members, and other persons who are involved with these young people.

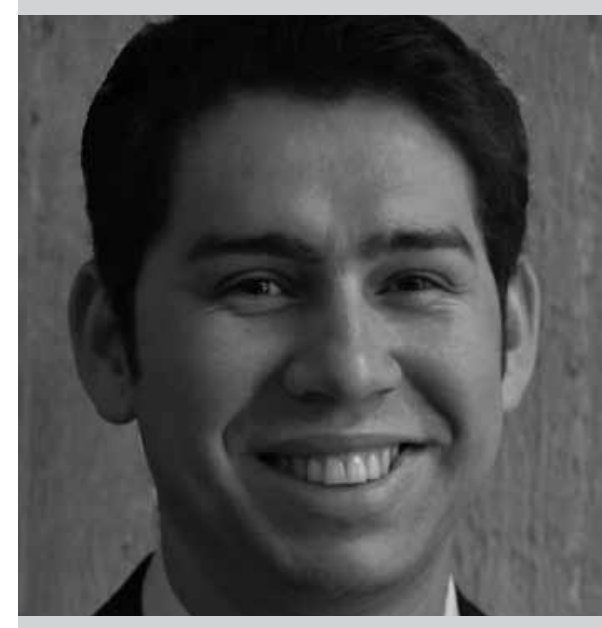

Mr. Cléssio Moura de Souza is a Brazilian citizen. In October 2011, he was admitted to the IMPRS REMEP at the MPI for Foreign and International Criminal Law at the age of 31. Cléssio obtained an LL.B degree from the Pontifical Catholic University of Rio de Janeiro, Brazil in 2006, and a LL.M degree from Freiburg University in 2011 . He is funded by the Max Planck Society. The conclusion of his doctoral thesis is expected for Dec. 2013. Cléssio is enrolled at the Faculty of Law at Freiburg University. Prof. Dr. Hans-Jörg Albrecht and Prof. Dr. Walter Perron are his supervisors.

Publications (selection):

- Moura de Souza, Cléssio. Straftaten Jugendlicher in Brasilien. Monatsschrift für Kriminologie und Strafrechtsreform. 93. Jahrgang, Heft 3 (Juni) 2010, S. $230-242$.

- Moura de Souza, Cléssio. Teenagers, Violence and Crime in Brazil. Freedom from Fear Magazine. Issue 8, Dez. 2010 (online journal).

- Moura de Souza, Cléssio. El “Ato Infracional” en Brasil. In: Anuario de Justicia de Menores. Astigi, 2009, Issue/Volume IX, p. 273 - 292. 


\section{Organizing Accountability and Criminal Justice in South Africa}

How are South African criminal justice employees, who call others to account for wrong doings, held accountable? Moreover, to whom and for what, according to which standards, with what mechanisms and with what effects and consequences? These are the questions that lie at the heart of this $\mathrm{PhD}$ project. Interest in and demands for accountability are particularly urgent in a context like the new democratic South Africa, which still has to grapple with the legacy of an - for the most part entirely - unaccountable apartheid state.

With its focus on the running of state institutions, the project contributes to the understanding of what role state criminal justice institutions play in the establishment, negotiation and maintenance of social order in post autocratic societies. Here the question of trust is of particular interest. How do post autocratic criminal justice institutions, which have been distrusted since they were the scaffolding of a repressive social order, re-establish relationships of trust?

A key strategy is to establish mechanisms of accountability. These are supposed to give citizens confidence in the reasonableness and fairness of state demands and actions. Their aim is to minimize unpredictability and arbitrariness, and to control discretion. The increasing interest in consensus on the importance and desirability of the concept of accountability however, does not come with consensus about its meaning.

Accountability is a variable social relationship and its terms are often vague, fiercely debated, and associated with diverse practices. It can be formal and informal, public and private, grounded in professional discretion and expertise, or with standardized routines and protocols. It has been associated with elections and electoral recall; rationalized, professionalized, and bureaucratic frameworks; judicial review; open and transparent government; market like mechanisms to enhance efficient, effective, and economic public services; or with being more responsive to or respectful of, the needs of the public.

For many years, though, the dominant version of accountability has been linked to quantification and measurement. The increasing use of formal quantitative measures and verifiable accounts in many settings has been criticized for shifting the standard of accountability to performance as a 'bottom line vision of accountability'; in other words, for narrowing down the understanding and practice of how accountability is defined and demonstrated.

This $\mathrm{PhD}$ project focuses on how the recent emphasis on quantitative accountability has shaped and influenced criminal legal practice in South Africa. Rather than treating quantitative forms of accountability as something inherently good or bad this project contributes with its in-depth empirical analysis of 'what numbers do in organizations' and 'what people do with numbers in organizations' to a more nuanced and critical understanding of their role and consequences.

While exploring the normative, social and political dimensions of quantification and classification practices within South African criminal justice institutions, the project is at the same time critical of the view of numerical omnipotence and the numerical rhetoric of control and dominance. Instead, it carefully describes the various webs of accountability different criminal justice actors have to attend to (with a focus on prosecutors, police men and managers) as well as how they translate these diverse organizational demands into practice.

By using accountability relationships and quantification as a lens to understand how complex social projects, like 'delivering justice' are accomplished, the study brings the everyday work of regulatory authorities - particularly institutions of punishment in post-autocratic settings - into focus. 


\title{
Retributive vs. Restorative Justice in the Northern Uganda Conflict
}

\author{
A Case for Selective Justice; the Application of Different Forms of Criminal Justice
}

This project concerns the complexities of an atrocious conflict in northern Uganda that have presented serious challenges to the International Criminal Court (ICC) and its role in administering justice. It is suggested that without careful analysis and approach, the ICC is destined to present an antagonistic precedent for criminal justice systems worldwide, notwithstanding the relationship between countries involved (Sudan, DR Congo, Uganda, and others), and the psychosocial and economic development dilemmas accompanying conflicts in such countries. Government positions in these conflicts with regard to causes and statutory responsibilities to victims is also questioned. Promises of peace from governments give hope, however such promises are rarely fulfilled. The role of invisible actors/supporters, the victims' attitudes themselves and other quiet but significant parties, only complicates the design of strategies to deal with or prevent gross human rights violations. Although the ICC's involvement in the Uganda conflict was warranted, pursuing justice in the midst of conflict has led to more complexities. Moreover, much local discontent and mistrust surrounds the work of the ICC. Although this may be because the ICC is based on a retributive justice model while local efforts are based on a restorative justice model, these local efforts have themselves yielded little if any result in regard to ending the wars or preventing atrocities. Yet there is no doubt that international crimes and gross violations of human rights in the region are both evident and ongoing; a fact that warrants international in- tervention. The criminal complications of the war in northern Uganda are coined by several factors. The conflict is shaped by attitudes of the parties and individuals involved; the socioeconomic, political and historical connotations; and the influence of other countries in the region as a whole. So, which way do we go? Should we seek restoration or should we punish? Also, who or what should be restored or punished? These questions have not been answered concretely by most studies on this subject and region.

The main research question here is: "In view of the complexity, geographical scope and kinds of crimes, as well as the type of perpetrators and perceptions of victims, which form of justice is best applicable in the northern Uganda conflict and what implications exist for such an application to criminal justice systems?" The study answers this question by exploring the actions executed by parties in the conflict, the attitudes/perceptions of victims towards perpetrators, and the ways in which victims address the aftermath of the atrocities in view of forms of justice being sought.

Through intensive interviews, data was collected in the field and analyzed. The findings have been streamlined so as to expound on the role of international criminal law, psychology, sociology and history in the construction and reconstruction of social order and to explain retaliation, mediation and punishment, which are the core concepts of the REMEP program.

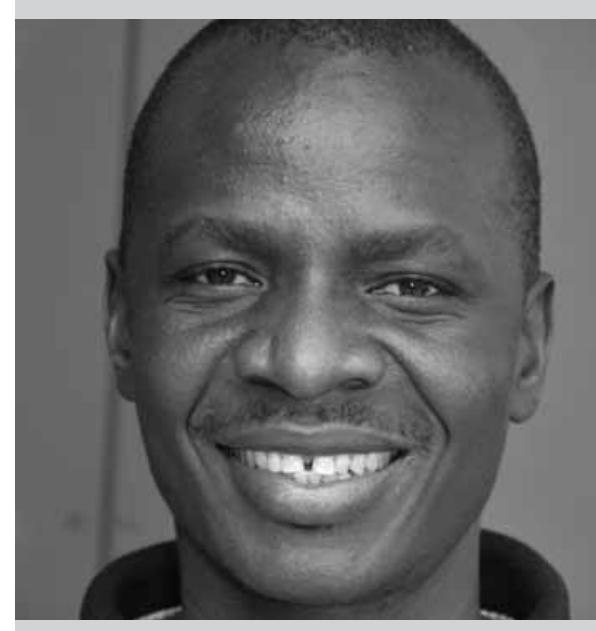

Mr. Nathan Muwereza is a Ugandan citizen. In August 2010, he was admitted to the IMPRS REMEP at the MPI for Foreign and International Criminal Law at the age of 38. Nathan obtained a diploma in education in 1998 from the institute of Teacher Education of Kyambogo University, Uganda, a B.Sc degree from Makerere University, Uganda, in 2003, and a M.Phil. degree in 2007 from Cambridge University, UK. He is funded by the Max Planck Society and the Katholischer Akademischer Ausländer Dienst (KAAD). The conclusion of his doctoral thesis is expected for July 2013. Nathan is enrolled at the Faculty of Philosophy at Freiburg University. Prof. Dr. Hans-Jörg Albrecht and Prof. Dr. Trutz von Trotha, professor emeritus of sociology from the University of Siegen, are his supervisors. Priv.-Doz. Dr. Dietrich Oberwittler, senior researcher and research group leader at the MPI for Foreign and International Criminal Law, is his day-to-day supervisor.

Nathan has been on an extended fieldwork stay in Gulu (Uganda) among victim communities of the war in Uganda and Sudan from 01.01 .2011 to 30.09 .2011 .

Publication:

- Muwereza, N.: Status Offenders and the Psychosexual Gap in the Ugandan Law Regarding Defilement4. In: Journal of Science and Sustainable Development, vol. 3, no. 1 (2010), pp. $149-163$. 


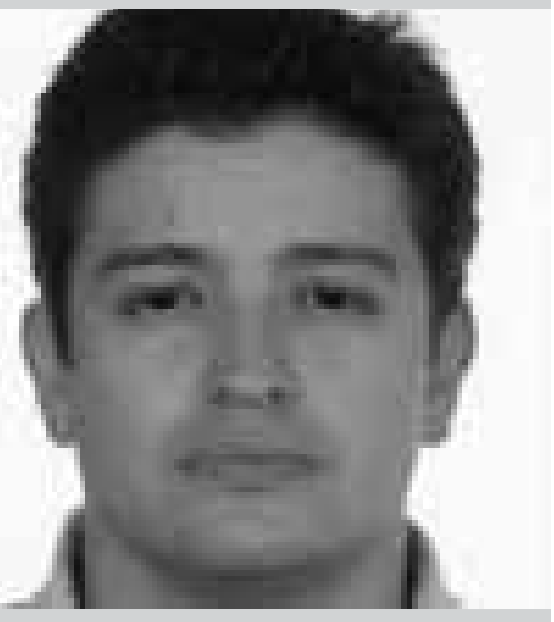

Mr. Gustavo Rojas Paez is a Colombian citizen. In October 2010, he was admitted to the IMPRS REMEP at the MPI for Foreign and International Criminal Law at the age of 31. Gustavo became an Attorney at Law in 2006 after studying law at the Universidad Libre de Colombia, Bogotá. In 2008 he obtained a M.A. degree in Sociology of Law from Onati University. He receives a scholarship funded by the German Academic Exchange Service (DAAD). The conclusion of his doctoral thesis is expected for September 2012. Gustavo is enrolled at the Faculty of Law at Freiburg University. Prof. Dr. Hans-Jörg Albrecht, Dr. Pablo Galain Palermo, Head of Section at the MPI for Foreign and International Criminal Law, and Prof. Dr. Walter Perron are his supervisors.

Gustavo conducted interviews in Colombia from 15 Sept. 19 Oct. 2011.

Publication (selection): - Olarte, Carolina / Rojas Paez, Gustavo (eds.): Spanish Translation of "Law as Resistance:

Modernism, Imperialism, Legalism". Ashgate, Aldershot - Peter Fitzpatrick (2008) [El Derecho como Resistencia: Modernismo, Imperialismo, Legalismo]. Bogotá, Siglo del Hombre, Universidad Libre, forthcoming 2011.

\section{Transitional Justice from Below: Chances and Prospects in Contemporary Colombia}

Over the past decades the subject of Transitional Justice (herupon TJ ) has gained global and political interest. The scope of the subject and the issues it is supposed to address have given way to an interesting theoretical debate that has brought together insights from sociology, criminology, political science, law, history, and anthropology .One of the main challenges of contemporary TJ concerns its implementation and effectiveness when armed conflicts occur. Since 2002, a manipulative discourse on transitional justice started in Colombia, in the context of an ongoing armed conflict in which the interests of elements of the state, guerrilla groups, right-wing paramilitaries, and mafia barons have overlapped (Uprimny and Saffon, 2009).In 2003, the Colombian government signed a peace agreement with only one actor of the conflict: the right-wing paramilitaries. The signing of this peace agreement and the subsequent enactment of the "Peace and Justice Law" have given rise to fraught debates on justice and impunity that have juxtaposed the interests of the Colombian government, the paramilitary leadership, and the elites on the one hand, with those of local and international NGOs and human rights activists and minority groups such as African Colombians and peasants organizations on the other (Diaz 2009). This contestation of the Colombian TJ framework provides the starting point for the proposed project, which aims to take advantage of this unique window of opportunity and observe and analyze the process of transitional justice in the making. In particular, the project will explore chances and possibilities for "Transitional Justice from below." It will ask about the shape and form of viable procedures of TJ

\section{References:}

- Diaz, C (2009) Colombia's bid for Justice and Peace. In Ambos, Large and Wierda (eds). Building a future on Peace and Justice. Springer, Berlin.

- Mc Evoy K and Mc Gregor L (eds) (2008) Transitional Justice from Below. Grassroots Activism and the struggle for change. Hart, Oxford. that may emerge and develop in Colombia during the next years, and it will question which narratives of contested notions such as justice and transition may emerge in a setting in which violence and human rights violations continue to take place.Transitional justice from below is a new paradigm that challenges established and state-centered procedures of TJ (Mc Evoy and Mc Gregor 2008). It comprises a range of activities at the grass-roots level which are often undermined by legalistic approaches to conflict resolution. The project will attempt to identify pathways and factors as well as obstacles for the development of this new paradigm of TJ in an ongoing conflict. In particular, it will observe the chances of TJ from below and explore communitarian understandings of peace, justice, and forgiveness in a country that is undergoing one of the longest armed conflicts in the world. The project will follow the process of TJ in the making, both top down and bottom up. It will explore in which ways both are linked together in the complex interplay of power dynamics that nourish the highly contested transition of Colombia. Given the array of social actors, NGOs, and local communities that use transitional justice discourses as a strategy to fight against impunity and build peace, a multidisciplinary approach that draws on criminology and law, political science, and sociology is necessary. Legal anthropology may also prove to be a very important supplement. The multidisciplinary research agenda of REMEP lays out an opportunity to theorize and research these new forms of TJ, which are shaped by categories such as reconciliation, retaliation, and punishment.

- Saffon, M and Uprimny, R (2009) Uses and abuses of Transitional Justice. In Bergsmo and Kalmanovitz (eds) Law in Peace negotiations. International Peace Research Institute in Oslo. (PRIO). 


\section{International Criminal Justice on Trial: the Legal Implications of the Referral Practice of Cases from International to National Justice Mechanisms}

\section{The ICTY/ICTR Experience and its Possible Relevance for the ICC}

The 20th century has witnessed the rapid proliferation of a variety of international and internationalized criminal courts and tribunals (ICTs), whose creation have been justified by the International Community's resolve to punish perpetrators of the gravest international crimes so as to contribute to restoring peace and justice to (post-) conflict regions. A comparison of the various courts and tribunals reveals a range of different "justice" models, with specific legal frameworks and jurisdictional features determining each ICT's relationship with, inter alia, relevant sources of law and national judicial institutions. The specific contours of the relationship between the ICTs and relevant national accountability mechanisms continue to be subject of some uncertainty, not least in light of the fact that national courts have now increasingly begun to prosecute international crimes. This growing trend is also consonant with the complementarity principle of the new permanent International Criminal Court (ICC), which is premised on the understanding that national courts are best suited to prosecute international crimes themselves.

Given the sheer scale of the crimes committed, and the limited resources of ICTs, it is crucial that these courts function in parallel with national/local courts in a pluralistic integrative system of international criminal law (ICL). At the same time, parallel judicial activities are giving rise to an array of complex legal conundrums. Contemporary legal discourse is therefore increasingly focusing on the practical and theoretical implications of a certain 'diversification' (also referred to as 'fragmentation') of the body of ICL, not just on an institutional level but on a procedural and substantive one as well.

While many academic contributions have focused on the deferral of cases from national courts to ICTs, less attention has been paid to the opposite practice, namely referrals from international tribunals to domestic courts.
The referral practice of the International Criminal Tribunals for the Former Yugoslavia and Rwanda (ICTY and ICTR respectively) to national courts as a crucial component of the U.N. Security Council formulated Completion Strategy, which sets a date by which the tribunals should conclude definitively trial and appellate activities, illustrates - in a highly concrete manner - various legal challenges arising from pluralistic accountability mechanisms in the prosecution of international crimes. The effective implementation of the Completion Strategy is contingent on the tribunals' ability to transfer cases and investigative materials to national jurisdictions for prosecution.

The referral practice lends itself well to a study as it evinces the complex interplay between normative actors, legal orders, sources of law, and other normative projections. This interplay is part of a greater trend, which is becoming increasingly relevant as the ICC starts adjudicating its first cases. The referral practice could also be relevant for the ICC, despite its different jurisdictional framework.

The PhD project's first research objective is to examine the most significant legal conundrums caused by the transfer of cases and investigative materials from the ICTY/R to national courts. The second objective is to understand possible root causes of such legal conundrums. The third objective is to formulate possible solutions. The fourth objective is to ascertain how such solutions could be transplanted into the ICC context. The fifth objective is to draw general conclusions about pluralistic interactions of different legal systems and norms in the ICL fora today and thereby to contribute to the growing debate regarding the theory of legal pluralism.

Research methods comprise an in-depth analysis of relevant norms, judicial decisions and trancripts emanating from the ICTY, ICTR, ICC and national courts, as well as a literature review and experts interviews.

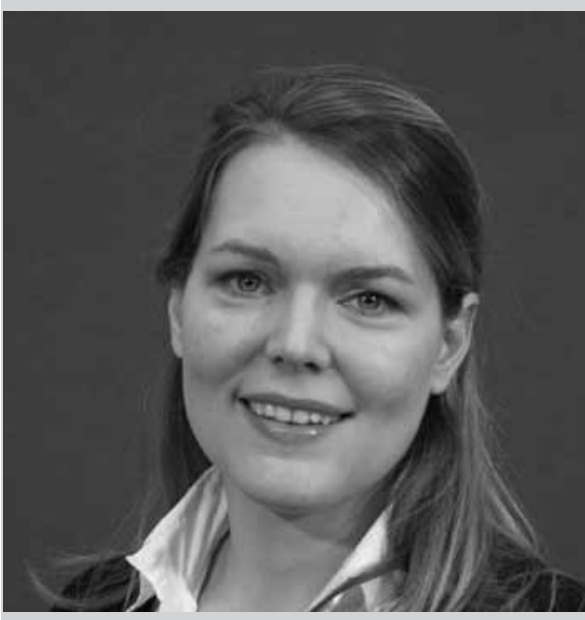

Ms. Jennifer Schuetze-Reymann is an American and German citizen. In April 2009, she was admitted to the IMPRS REMEP at the MPI for Foreign and International Criminal Law at the age of 31. Jennifer obtained a LL.B and B.C.L. degree from McGill University, Canada, in 2003, and a LL.M degree in 2005 from the Institute of Comparative at Law McGill University. She receives funding by the Max Planck Society. The conclusion of her doctoral thesis is expected for March 2012. Jennifer is enrolled at the faculty of law at Freiburg University. Prof. Dr. Ulrich Sieber and Prof. Dr. Walter Perron are her supervisors. 


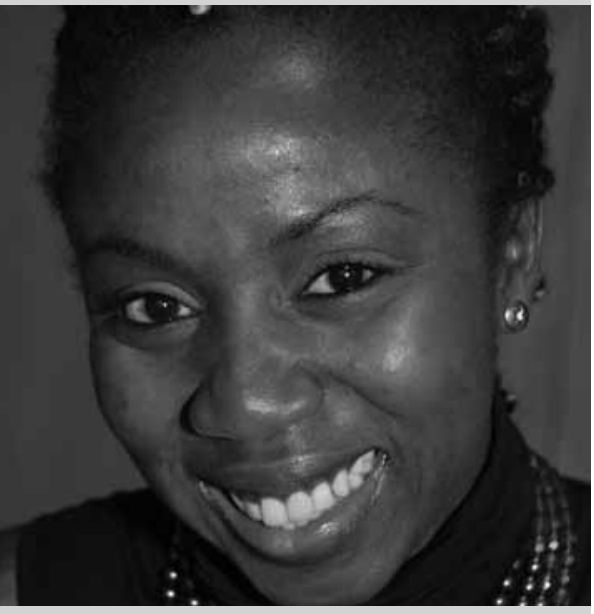

Ms. Adpeju Solarin is a an American and Nigerian citizen. In August 2011, she was admitted to the IMPRS REMEP at the MPI for Foreign and International Criminal Law at the age of 30. Adepeju obtained a B.IS degree in 2004 and a M.LS degree in 2010 from Minnesota University, USA. She is funded by the Max Planck Society. The conclusion of her doctoral thesis is expected for the end of 2013. Peju is enrolled at the faculty of philosophy at Freiburg University. Prof. Dr. Jürgen Rühland, Chair in Political Science, Fellow of Freiburg Institute for Advanced Studies, and Prof. Dr. Hans-Jörg Albrecht are her supervisors.

Publications (selection):

- Solarin, 'Peju. 2010. "Circles: A Place to Hear and Be Heard." Minnesota Women's Press, October.

- Solarin, Adepeju. 2010. "America and Iran: Restorative Practices as Supplement to Diplomatic Efforts?" Unpublished Manuscript, University of Minnesota, Master of Liberal Studies, May 7.

- 'Peju Solarin. 2009. "ESC 2009: Ljubljana or is it Ljubljena the Beloved!" Criminology in Europe 8(3): 1, 4-5.

- Harrop, Sara, and 'Peju Solarin. 2008. "Edinburgh: Another Scottish Victory." Criminology in Europe 7(3): 1, 10-11.

\section{Adepeju Solarin}

\section{Restorative Justice Peacemaking Circles: What Relevance to Intractable Conflicts?}

For close to 40 years, the countries of Iran and America have been embroiled in an intractable conflict that has shaped their foreign policy towards each other. The origins of the conflict, significant they may be, no longer seem critical in understanding how reconciliation and peace can be negotiated between these two countries. This research proposal attempts to explore the viability of restorative justice peacemaking circles in the peacebuilding toolkit of mediation (diplomacy). The question may be posed: what other alternatives to mediation can be explored given the challenge of an intractable conflict such as the one between Iran and America? This question may be answered through a thorough literature review, de-classified documents on the two countries, and several circle observations of opinionmakers on both sides.
This topic is of particular important especially in its pre-war stage. A cursory review of mediated (diplomatic) efforts by both countries do reveal some good faith gestures at different intervals that were misunderstood or ignored by the other. Such unsuccessful efforts continue to persuade decisionmakers (on both sides) of the futility of any form of mediation. The guiding pricinples of equality, responsibility, and accountability, inherent in peacemaking circles, are worth examining especailly when powerful entities are involved. It should be noted that this research does not attempt to solve a 40year conflict, but questions if there may lie, within peacemaking circles, a different way to approach this conflict, thus building a foundation upon which peace and social order may be negotiated. 


\title{
Procedures of Dispute Management in 'Post-War' Times
}

\author{
A Disputing Parties Account, Bamyan/Afghanistan 2009
}

The present research concerns the realisation of procedures of disputing under the special circumstances of so-called 'post-war' times, accounting for and analysing disputing parties' assessments and practices.

These special circumstances were caused by recurrent large shifts in power relations and immense changes in the social order during the last decades of civil and regional wars and regime changes. In consequence, these changes led to an immense diversification on the sociocultural, institutional, and normative level. This diversification puts the order of disputing up for fundamental negotiation, provides for a highly pluralistic and unsettled legal field, and makes the order of disputing subject to a multitude of large- and small-scale legal and political interventions. All this is typical for post-war times.

The research contributes to the understanding of this setting by analysing how disputing parties themselves assess these times, the consequences these emic assessments have on their dispute management and, through that, on the realisation of procedures of disputing. The project follows disputing parties through their dispute management and analyses their decision-making processes in regards to questions crucial for the realisation of procedures of disputing. These questions include: who is regarded to be a party, how is the decision made to blame and by that to establish a disputing relationship, what defines the aims of the disputing process, how are third parties dealt with, and finally how are the results and at least temporary endings of disputing processes dealt with.

These detailed analyses not only confirm the general assessment of normative plurality and an unsettled legal order. They also point to the problem of uncertainties parties are confronted with in their decision-making: Uncer- tainty about the other parties' means, interests, and normative convictions, about institutional agendas and practices, as well as the social relationships that disputing relationships are based on - in short, uncertainty about information crucial for decision-making in disputing. However, the analyses also show the impact that uncertainty about the future has, which by most is expected to be the continuation of the past experience of recurrent fundamental socio-political change and even war. This expectation of fundamental future changes in the sociopolitical organisation has tremendous effects on decision-making in disputing mechanisms: It closes the time-frame disputing strategies are based on in a manner not envisaged by the available normative orders and does not allow for sustainable solutions based on the parties' interests. It further effectively inhibits the renegotiation of norms of legitimacy that a reliable order of disputing would require, even for those who engage in a negotiation of the future in normative terms. Disputing mechanisms such as retaliation, mediation, and punishment thereby turn into means of negotiating power rather than justice and are defined by those parties in power rather than those who might be legitimised on normative grounds. This is not only perceived as a continuation of the officially past war times, it also delegitimizes the current enterprise of state-building and inhibits peace-building in socio-legal regards, despite Bamyan being politically peaceful in 2009 .

Analysing disputing parties' decision-making processes thereby not only contributes to an understanding of the production of procedures and mechanisms of disputing and the workings of a legal order in times of fundamental change. It moreover emphasises the importance of how actors interpret these circumstances based on their experiences with the past and expectations of the future socio-political order in general and position themselves towards it.

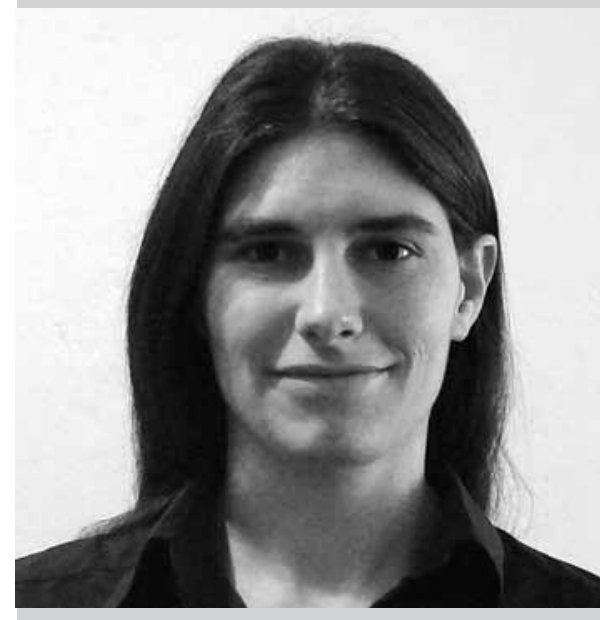

Ms. Friederike Stahlmann is a German citizen. In April 2008, she was admitted to the IMPRS REMEP at the MPI for Social Anthropology at the age of 28 . Friederike obtained a M.A. in Religious Studies from PhilippsUniversity Marburg and Free University of Berlin, in 2005. In 2007 she obtained a M.A. in International and Comparative Legal Studies from The School of Oriental and African Studies at London University, UK. She is funded by the Max Planck Society. The conclusion of her doctoral thesis is expected for March 2012. Friederike is enrolled at the University Halle-Wittenberg. Prof. Dr. Günther Schlee and Prof. Dr. Keebet v. Benda-Beckmann are her supervisors.

Friederike did her fieldwork in Bayman, Afghanistan, from November 2008 until December 2009. 


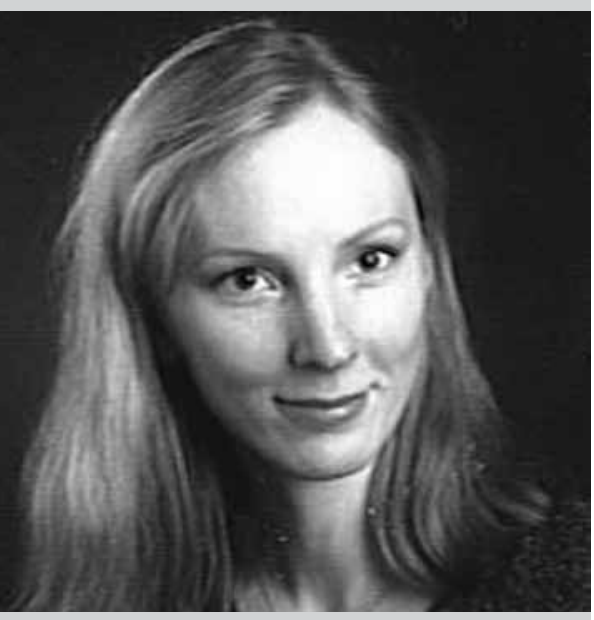

Ms. Inga Švarca is a Latvian citizen. In March 2009, she was admitted to the IMPRS REMEP at the MPI for Comparative Public and International Law at the age of 32. Inga obtained a Dipl.-jur. from Latvia University in 2000 and a LL.M. degree in International and European Law from Riga Graduate School of Law, Latvia, in 2001. She was funded by the Max Planck Society. The conclusion of her doctoral thesis is expected for February 2012. Inga is enrolled at Hamburg University's Faculty of Law. Prof. Dr. Rüdiger Wolfrum is her supervisor.

Publications (selection): - Švarca, Inga: Ubuntu in the transitional justice mechanisms of South Africa. In: Diedrich, F. (ed.): Ubuntu, Good Faith and Equity: Flexible Legal Principles in Developing a Contemporary Jurisprudence. Claremont, Juta, 2011, p. 115.

- Švarca, Inga / Diedrich, Frank: Intellectual Property Law in Latvia. In: Blanpain, R. (general editor): International Encyclopaedia of Laws. Leiden, Kluwer Law International, 2006.

- Švarca, Inga / Diedrich, Frank Unfair Calling under international Bank Guarantees - Fraud and the Principle of Independence. In: Internationales Handelsrecht Zeitschrift für das Recht des Internationalen Warenkaufs und -vertriebs, vol. 4, p. 133 - 176, July/August 2004, p. 139 - 147

\title{
Inga Švarca
}

\section{The Procedure of the European Court of Human Rights Regarding Countries in Transition}

\author{
The ECtHR's Transitional Justice Cases Against Latvia
}

The promulgation of procedural law for international courts and tribunals has long been a neglected and underestimated issue. This should, however, be changed as international judicial bodies are often concerned with states that have different levels of development in respect of democracy, the rule of law, and the implementation of human rights. Often a fair and transparent procedure for settling conflicts stemming from the transition to a democratic state is more important for the affected persons. Moreover, countries will have different national and international problems depending on whether they belong to established democracies or whether they are still in transition. This calls for a different set of methods and approaches when dealing with issues concerning states that can be labeled as "new" democracies or countries in transition as, for instance, Latvia.

The research focuses on the European Court of Human Rights' ("ECtHR”) cases against Latvia that involved transitional justice issues as a result of the application of transitional justice mechanisms by Latvian state authorities.

One of the results of this analysis is that the ECtHR has not applied a consistent legal procedural approach to transitional justice cases coming from Latvia. This is a startling result because it seems that different approaches have been applied under the auspices of the European Convention on Human Rights ("Convention"). The thesis therefore urges the ECtHR to consider the following recommendations when adjudicating transitional justice cases:

First, the ECtHR should use clearer language on transitional justice, i.e., it should explicitly mention and admit the transitional justice context of the respective cases.

Second, the ECtHR should consistently and explicitly differentiate between transitional justice cases and non-transitional justice cases.

Third, the ECtHR should take a consistent approach as to whether and to what extent it contributes to the transitional justice processes of its member states, choosing between judicial restraint and judicial activism.

If preferring judicial activism, namely deciding to adjudicate transitional justice cases, the ECtHR should modify its procedure in order to adopt the particularities of such cases and countries in transition.

If the goal of the ECtHR is to safeguard the human rights standards set by the Convention and thereby creating justice in the individual case, the factual and legal peculiarities of member states in transition have to be taken into account procedurally.

The thesis proposes that the ECtHR should consider introducing reconciliation and mediation, as well as a transitional justice mechanism such as truth-seeking, for the adjudication of transitional justice cases.

The implementation of the aforementioned recommendations - with the consent and cooperation of the member states - is feasible due to the ECtHR's procedural flexibility and its almost unrestricted competence to decide on its tasks. Accordingly, the thesis recommends amending the procedure of the ECtHR in two ways: through judge-made law (de lege lata) and eventually by introducing amendments to the Rules of Court (de lege ferenda).

It is only quite recently that the notions of "transitional justice" and "reconciliation" have been addressed in respect to inter/supranational courts. It used not to be the task of an international court to re-conciliate nation states in transition. However, the ECtHR still has a very important role and is necessary with its - even limited - contributions for countries in transition.

The thesis forms a part of the general research agenda of the REMEP which focuses, inter alia, on how wrongs are addressed and dealt with by national and/or international actors in order to (re-)establish and maintain lasting peace in post-conflict societies or, in other words, countries in transition. 


\section{Carolijn Terwindt}

\section{Ethnographies of Contentious Criminalization}

\section{Expansion, Ambivalence, and Marginalization}

This dissertation addresses the challenge of liberal democracies to deal with fundamental conflicts in society about, for example, political representation and natural resources. Failing to deal with competing demands in the political arena, the research zooms in on the processes that transfer the dynamics of these conflicts into the criminal justice arena. Mobilization and discursive action of "victims" and "prisoner supporters" aim to push or challenge criminal prosecutions. The research describes the way in which such conflicts fundamentally alter the logic and development of criminal prosecutions. In an exploration of tensions between law and justice, the dissertation analyzes criminalization processes in three contentious episodes: the Chilean-Mapuche territorial conflict, the Spanish-Basque separatist conflict, and the eco-conflict in the United States. While prosecutors assert their independence and the democratic mandate to "simply" enforce the law, the research describes the gradual politicization of criminal proceedings as opposing actors implicated in the political struggle move into the criminal justice arena and make it subject to and the space of claim-making.

October 1997, United States: Six raids in the Midwest just before the pelting season; between 8,000 and 12,000 minks released, two fur farms out of business. Opposing interpretations either emphasize the enormous economic losses for these farming families or joy that many animals escaped death for profit.

October 1999, Chile: a forestry plantation is set on fire in the south of Chile. The plantation belongs to a large forestry company owning 391,000 ha of plantations while an adjacent indigenous Mapuche community claims historical right to the land. Opposing interpretations either indicate anger about the economic loss for the forestry company and the lack of a rule of law or happiness to see the invasion of imported water-consuming trees turned into ashes.

March 1992, Spain: three Molotov cocktails set the offices of the national train company in Bilbao on fire. Opposing interpretations either claim this is terrorism and related to the armed organization ETA or view it as some youths expressing their anger because of police violence during a demonstration earlier that day.

Each of these incidents formed the material for criminal prosecutions. The events were subject to a struggle of interpretation. The criminal proceedings were as much a site for this struggle as a significant contributor in this struggle. The dissertation provides an analysis of the contestation of different interpretations in the criminal proceedings in major domestic political conflicts in the US, Chile, and Spain. In the US, eco-activists demand the closure of an animal testing company, the end of experimentation with animals, and restrictions on logging companies. In Chile, Mapuche activists reclaim the lands that they have lost since their reduction in reservations in 1881. In Spain, Basque left nationalists fight for an independent and socialist Basque Country. In each of these conflicts many contentious actions continue to occur that come to the attention of the government with a claim to criminal investigation and prosecution.

The specific focus of the dissertation is on the legitimization strategy the prosecutor employs. This strategy ordinarily results in criminal proceedings conforming to the principles of "autonomous law" or "formal rationality." The idea of formal rationality draws on a distinction between formal procedures and substantive justice. This approach is supposed to serve both the short term interest of terminating violence and restoring order, and the longer term interest of maximizing the legitimacy of the government. However, various studies indicate that formal rationality might be abandoned in emergency situations. Rather than assuming that the criminal justice system and its performance are fixed and given, the researcher has approached this institution from the perspective that it may be challenged and can subsequently change its performance. If so, the question is when and how. This dissertation provides three in-depth case studies on this phenomenon, by analyzing how the ongoing struggle for interpretation shapes the process of criminal interventions.

\section{Literature:}

Reenen, Piet van. 1979. Overheidsgeweld. Een sociologische studie van de dynamiek van het geweldsmonopolie. Alphen aan den Rijn : Samsom Uitgeverij.

Nonet, P., and P. Selznick. 2005. Law and Society in Transition: Towards Responsive Law. New Brunswick: Transaction Publishers.

Balbus, Isaac. 1973. The Dialectics of Legal Repression. Black Rebels before American Criminal Courts. New York: Russell Sage Foundation. (Balbus 1973:13).

Weber, Max. 1978. Economy and Society. An Outline of Interpretive Sociology. Edited by G. Roth and C. Wittich. Berkeley, Los Angeles: University of California Press, pp. 656-657

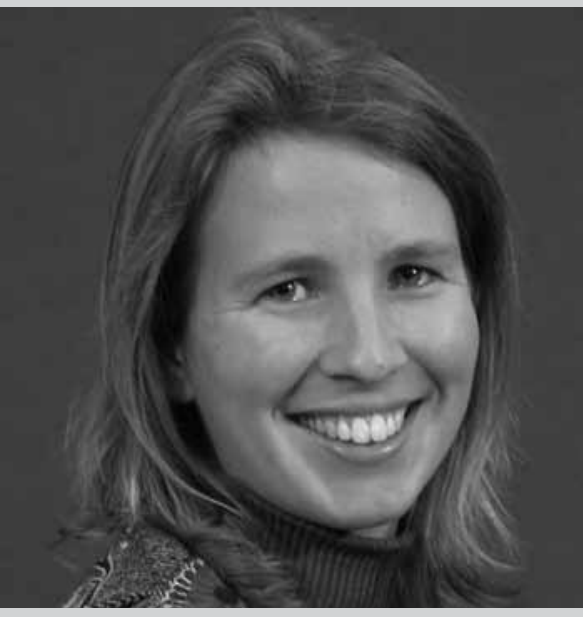

Ms. Carolijn Terwindt is a Dutch citizen. In August 2009, she was admitted to the IMPRS REMEP at the MPI for Foreign and International Criminal Law at the age of 30. Carolijn obtained a M.Sc. degree in Cultural Anthropology and a LL.M degree in Criminal Law and Criminology in 2004 from Utrecht University, Netherlands. In 2008, she obtained a LL.M. degree from Columbia Law School, USA. She is funded by the Max Planck Society. Carolijn was enrolled at Columbia Law School, USA and successfully defended her thesis in November 2011. Prof. Dr. Jeffrey Fagan, Prof. Dr. Elisabeth Povinelli and Prof. Dr. Daniel Richman, professors at Columbia Law School, and Prof. Dr. HansJörg Albrecht were her supervisors. From Nov. 2012-2013 she will most likely be working as a PostDoc at the MPI for Foreign and International Criminal Law.

Carolijn has been doing her fieldwork in Chile (2009), in Spain (2008), and in the USA (2007).

Publications (selection):

- Terwindt, C.: Were They Tortured or Did They Make That Up? Ethnographic reflections on torture allegations in the Basque Country in Spain, in: Oñati Socio-Legal Series, No. 2 , 2011 (peer reviewed)

- Terwindt, C.: A Review of "The Moral Force of Indigenous Politics. Critical Liberalism and the Zapatistas", by Courtney Jung in: Nationalism and Ethnic Politics. July 2010, Issue 3 \& 4, pp.513-515

- Borgh, van der, Ch. / Terwindt, C.: In der Klemme. In: Welt-sichten, Mai 2010, Issue 5, pp.28-30.

- Terwindt, C.: The Demands of the "True" Mapuche: Ethnic Political Mobilization in the Mapuche Movement. In: Nationalism and Ethnic Politics, 2009, Issue Volume 15/2, pp.237-257 (peer reviewed). 


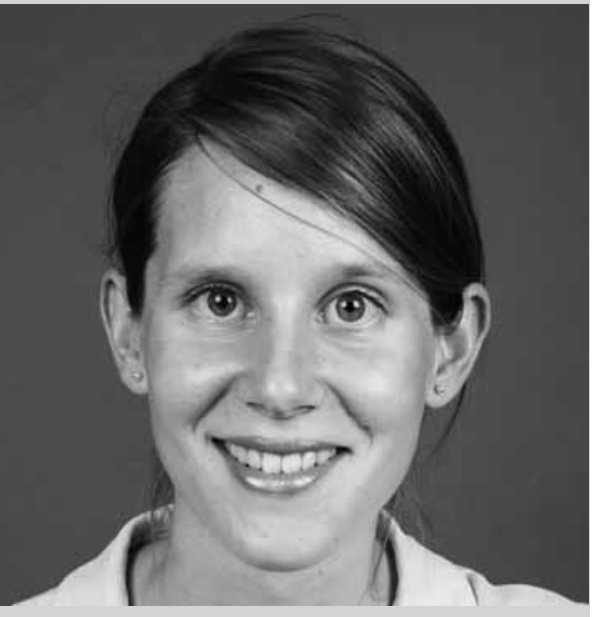

Ms. Lejla Vujinovic is a German citizen. In Sept. 2008, she was admitted to the IMPRS REMEP at the MPI for Foreign and International Criminal Law at the age of 26 while being a research associate at the University of Bern. Leila obtained a LL.M. in International and European Public Law from the University of Amsterdam, Netherlands, in 2007. She received a scholarship funded by the SNF (Schweizerischer Nationalfonds). The conclusion of her doctoral thesis is expected for February 2012. Leila is enrolled at the faculty of law at the University of Bern, Switzerland. Prof. Dr. Hans Vest, director at the Institute for Criminal Law, International Criminal Law and Legal Theory at the University of Bern and Prof. Dr. Hans-Jörg Albrecht are her supervisors.

Lejla conducted interviews and observations at the Court of Bosnia and Herzegovina from 18 May to 20 July 2009 and further fieldwork in Bosnia and Herzegovina from March 2009-December 2010.

She will pursue an academic career and is currently preparing her PostDoc for Sept. 2012-2013 in the United States.

Lejla Vujinović

\title{
Dealing with War Crimes in Bosnia and Herzegovina
}

\author{
Transitional Justice Mechanisms, Deals, and Public Perception
}

The project examines the transitional justice mechanisms that have been employed to date in Bosnia and Herzegovina in order to deal with the legacy of the 1992-95 armed conflict. The focus of attention is thereby on key aspects of war crimes trials, such as the retroactive application of new criminal law provisions and plea bargaining.

The projected developed from field research activities in Bosnia and Herzegovina between 2009 and 2011. Various research methods were used to obtain relevant data, such as war crimes trial observations, interviews with domestic legal professionals and laypersons, expert seminars for legal practitioners on key aspects of the newly introduced criminal legislation, and a court file and literature review.

While most courts try war crimes cases according to the law that was in force at the time the crimes in question were allegedly committed, Section I for the War Crimes of the BiH State Court applies the Criminal Code from 2003 retroactively. The problem is that crimes against humanity were not codified within SFRY criminal legislation, while the newly introduced Criminal Code from 2003 provides for the punishability of crimes against humanity. This study shows that trying war criminals for crimes against humanity is less a problem of lack of punishability, since crimes against humanity were already punishable under customary international law at the time in ques- tion. Rather, it finds that the problem with the retroactive application of the law lies more in the absence of a clearly defined punishment provision for crimes against humanity. Thus, the study concludes that prosecuting crimes against humanity in Bosnia and Herzegovina violates the prohibition of the retroactive application of the law as regards the punishment for crimes against humanity, while it does not violate the prohibition of retroactive application of the law as pertains to the punishability of crimes against humanity.

The study also examines the plea agreement practice in war crimes cases before Section I for the War Crimes of the BiH State Court. Plea bargaining has been introduced into the criminal justice system in Bosnia and Herzegovina in 2003 and has caused mixed feelings among both legal practitioners and the public in general. While plea agreements in war crimes trials are often defended on the basis that they are a means of obtaining key information about co-perpetrators, mass grave sites, and other key information on war crimes, the review of plea agreements shows that in fact the defendants' cooperation rarely forms part of the plea agreement. In addition, data from the plea agreements points to the fact that charge bargaining is regularly practiced in war crimes trials, although the criminal procedure legislation only provides for the possibility to sentence bargain with the defendant. 


\section{Legal Responses to Revolts during the French Revolution}

The Case of the Saxon Peasant Uprising of 1790

The study investigates the different legal reactions to revolts in the Holy Roman Empire from 1789 to 1806, from which the Saxon Peasant Uprising of 1790 stands out in terms of both intensity and spatial diffusion. Since the German public was thoroughly informed about the course of the revolution in France, German authorities assumed these revolutionary ideas influenced the revolts in Germany. Drawing from juridical, administrative, and normative sources as well as from contemporary treatises and other publications, this study seeks to uncover to what extent both authorities and private protagonists considered the revolts in late 18th century Germany to be distinguishable from prior revolts and what new threats they were deemed to pose to the political system of the Holy Roman Empire. Special attention will be paid to the question concerning the extent to which the criminal prosecution of the rebels reflected this perception of, and the discourse on, the revolts. Along with traditional punitive responses used to symbolically restore the infringed political order, such as the public execution of alleged ringleaders, the legal and political discourses as well as a wider range of possible reactions will be examined with regard to criminal justice, administrative practice, and social control. Moreover, the study investigates the specific criminal prosecution of the rebels and the ringleaders, as well as the preventive measures of social control taken against suspect social groups (for example, preachers and advocates) which the authorities considered responsible for both the revolts and the adoption of revolutionary ideas. However, revolts are not to be scaled down to a mere conflict between authorities and subjects; they, too, represent a conflict within the local societies. Thus, the measures aimed at the reintegration and social control of the prosecuted rebels - in order to prevent future violent riots - will also be discussed. By examining the process of pacifying revolts, the criminal prosecutions of the rebels, and the means taken to prevent future revolts in the era of the French revolution, the study seeks to contribute to the understanding of the role of retaliation, mediation, punishment, and repression in times of political and social unrest.

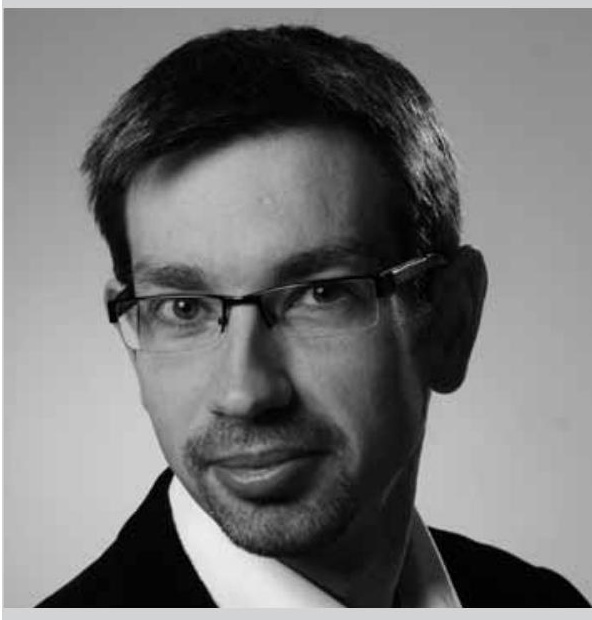

Mr. Thomas Walter is a German citizen. In March 2011, he was admitted to the IMPRS REMEP at the MPI for European Legal History at the age of 28 . Thomas obtained a M.A. in modern history, psychology and philosophy from the University of Jena and University of Jyväskylä, Finland, in 2010 . He is funded by the Max Planck Society. The conclusion of his doctoral thesis is expected for Dec. 2013. Thomas is enrolled at the Technische Universität Darmstadt. Prof. Dr. Karl Härter is his supervisor. 


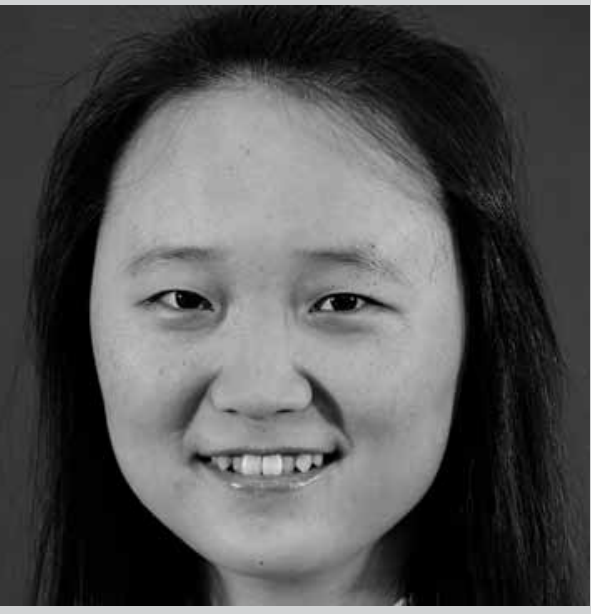

Ms. Chenguang Zhao is a Chinese citizen. In July 2009, she was admitted to the IMPRS REMEP at the MPI for Foreign and International Criminal Law at the age of 26. Chenguang obtained a LL.B. degree from Beijing Normal University, China, in 2005, and a LL.M. degree from the College for Criminal Law Science, Beijing Normal University, in 2008. She receives a scholarship by the Chinese Republic. The conclusion of her doctoral thesis is expected for June 2012. Chenguang is enrolled at the faculty of law at Freiburg University. Prof. Dr. Hans-Jörg Albrecht and Prof. Dr. Albin Eser, director emeritus at the MPI for Foreign and International Criminal Law, are her supervisors.

Publications (selection):

- Zhao, Ch.: Study on the Individual Criminal Responsibility under International Criminal law based on the Dividing Mode of Complicity System. In: Criminal Law Review, Vol. 26, 437-465 (2011), publ. by Law Press China.

- Zhao, Ch., Wei, Ch.: Issues on Validity of Criminal Law. In: New Tendency of Penology, Publ. by People's Public Security University of China, 56-62 (2007).

- Zhao, Ch.: On the Crime of Violating the Protection of Environment and Resources. In: New Tendency of Penology, Publ. by People's Public Security University of China, 332-336 (2007).

- Zhao, Ch.: Developments and Information of the Latest International Criminal Law Practice. In: China Review of International Criminal Law, Vol. 3, Publ. by People's Public Security University of China, 415-420 (2009).

\section{Chenguang Zhao}

\section{The ICC and China: The Principle of Complementarity and the National Implementation of International Criminal Law}

For a long time, a disconnection has existed between international and domestic justice. The relationship between international and domestic justice was treated as two autonomous systems, like yin and yang in Chinese. With the advent of the International Criminal Court (the ICC) which came into being on 1 July 2002 with the ratification of its founding treaty by 60 states, the two systems work increasingly in tandem. The principle of complementarity is one of the corner stones of the architecture of the ICC. It is an approach of "encouragement and punishment," as expressed in the Chinese saying by Xian Li Hou Bing "courtesy first and penalty second." Under the principle of complementarity, states have primary jurisdiction over the ICC. So long as the legal system of a state can efficiently investigate and prosecute the core international crimes prohibited in the Rome Statute, the ICC will not intervene. But if a state is unwilling or unable to investigate and prosecute these crimes, the ICC will invoke the principle of complementarity to step in. Therefore, the principle of complementarity has an impact on the national implementation of international criminal law, as well as on its exercise of jurisdiction in many aspects, including for third party states. Although China was actively involved in the Rome Conference, the Chinese delegation ultimately cast a negative vote. As a third party to the ICC that has neither signed nor ratified the Rome Statute, this does not mean that China can dissociate itself from the influences of the ICC or shirk responsibility for the suppression of core international crimes. Precisely the opposite is the case. Being a third party state to the ICC, China has ratified the genocide, torture and other international conventions and is obliged to prosecute these international crimes by implementing these international conventions into national law. However, the core crimes have thus far not been incorporated into Chinese criminal law.
Questions arise as to whether China is willing and able to prosecute core crimes and if so, on what legal basis.

This research work will focus on the possible impact of the principle of complementarity on the implementation of international criminal law in China as a third party state and the prospect of the relationship between China and the ICC based on this analysis. The extremely broad research program can be split into several core issues and central questions: How does complementarity operate? How does complementarity affect the identity of the ICC, and its role with respect to domestic jurisdictions? Why does the principle of complementarity matter for China? What is the status of national legislation and the prosecution of international core crimes in China and what are the causes of the current insufficiency? To what extent does the principle of complementarity have a catalytic effect on the domestic implementation of international criminal law in China and what reforms should be carried out? How can China take advantage of the principle of complementarity to protect its sovereignty and what future prospects exist for the relationship between China and the ICC?

The subject of this study is about the national legislation and punishment of core international crimes in China against the backdrop of the impact of the ICC. The philosophy of retaliation, mediation, and punishment constitutes the theoretical basis for the whole work which corresponds closely with the research agenda of the International Max Planck Research School on Retaliation, Mediation, and Punishment. Research methods consist of an analysis of relevant norms, international conventions, national and international jurisprudence, written media sources as well as a literature review. 

2. Members of Executive Committee and Teaching Faculty
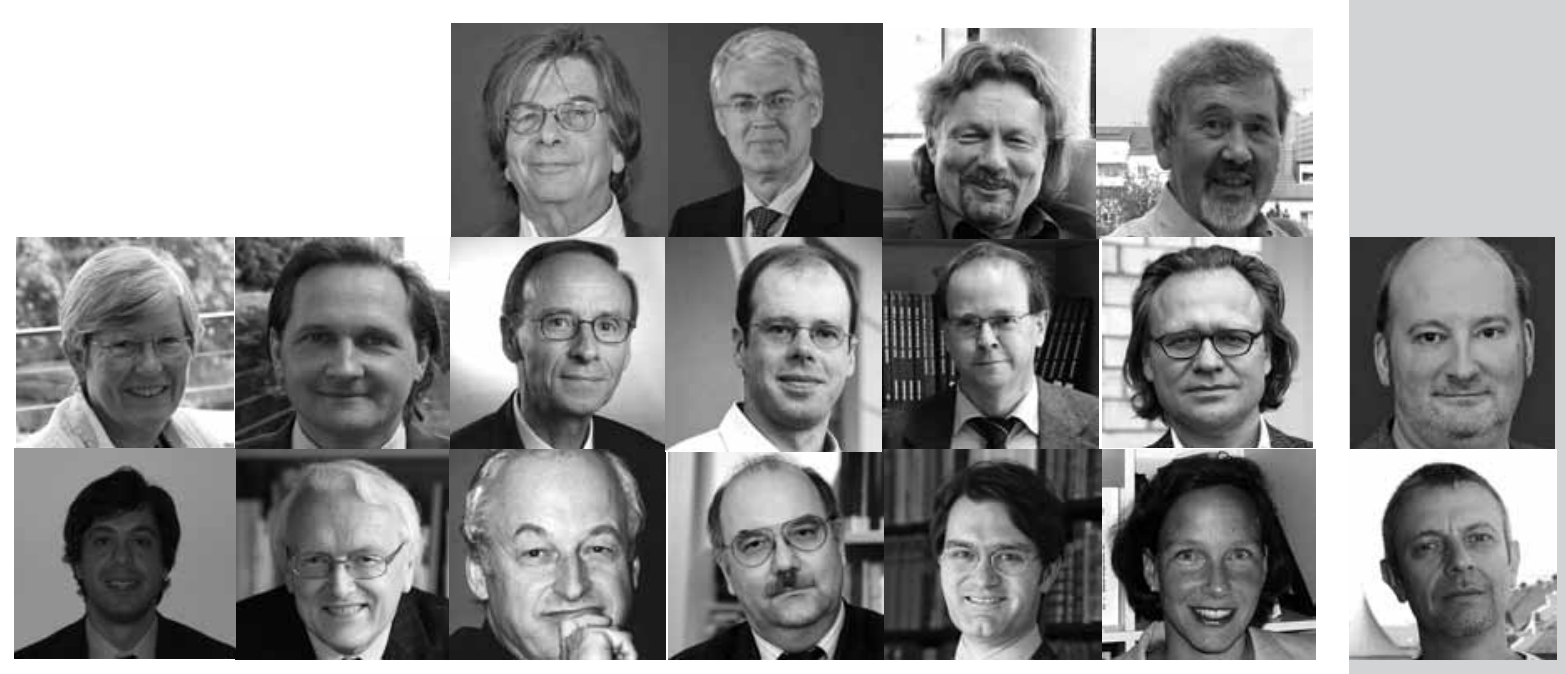


\section{Prof. Dr. Keebet von Benda-Beckmann}

Keebet von Benda-Beckmann is head of the "Project Group Legal Pluralism" at the Max Planck Institute for Social Anthropology in Halle/Saale, Germany; since 2003 she has been an Honorary Professor for Legal Anthropology at the University of Leipzig and since 2004 Honorary Professor for Legal Pluralism at the University of Halle/Saale. She has carried out research in West Sumatra and on the Moluccan Island of Ambon, Indonesia and among Moluccan women in the Netherlands. She has published extensively on dispute resolution, social security in developing countries, property and water rights, decentralization, and on theoretical issues in the anthropology of law. Together with Franz von Benda-Beckmann and Anne Griffiths she co-edited "Mobile People, Mobile Law. Expanding Legal Relations in a Contracting World” (Ashgate 2005). She also co-edited, with Franz von Benda-Beckmann and Anne Griffiths, "Spatialising Law" (Ashgate 2009) and, with Franz von Benda-Beckmann and Julia Eckert, "Rules of Law and Laws of Ruling: On the Governance of Law" (Ashgate 2009).

\section{Further information:}

http://www.eth.mpg.de/people/kbenda/index.html

\section{Prof. Dr. Thomas Duve}

Thomas Duve, born in 1967, is Director at the Max Planck Institute for European Legal History in Frankfurt (since 2009) and Professor for European Legal History at the Law Faculty of the University of Frankfurt. He is the editor of the journal "Rechtsgeschichte," co-editor of the forum historiae iuris, member of various advisory boards of journals and academic institutions, and principal investigator of the Cluster of Excellence "The formation of normative orders" at the University of Frankfurt. Furthermore, he is the spokesperson of the research focus "Extrajudicial and judicial conflict resolution," a joint research project between the Max Planck Institute, the University of Frankfurt, and the Frankfurt am Main University of Applied Sciences, which will begin its work in January 2012.

His main field of research is early modern European and Latin American legal history.

Further information:

http://www.rg.mpg.de/en/personen/thomas.duve/

\section{Prof. em. Dr. Wolfgang Frisch}

Wolfgang Frisch was born in Wernsdorf/Karlsbad in 1943. From 1962-1966, he studied law at the University of Erlangen-Nuremberg. There he wrote his doctoral thesis in 1970 and his Habilitation in 1974. In 1974, he became Professor for Criminal Law and Criminal Procedural Law at the University of Bonn. From 1976-1991, Professor Frisch held a Chair at the University of Mannheim. Since 1992, he has been a Professor of Law at the University of Freiburg and Director of the Institute for Criminal Law and Legal Theory. Since 2005, Professor Frisch has been an external scientific member of the Max Planck Institute for Foreign and International Criminal Law. Since 2006, he has been a full member of the Heidelberg Academy of Sciences and Humanities. His research focuses on general criminal law theory, legal theory, legal philosophy, criminal procedural law, the criminal sanction system, and international criminal law.

\section{Further information:}

http://www2.jura.uni-freiburg.de/institute/istr/default.htm
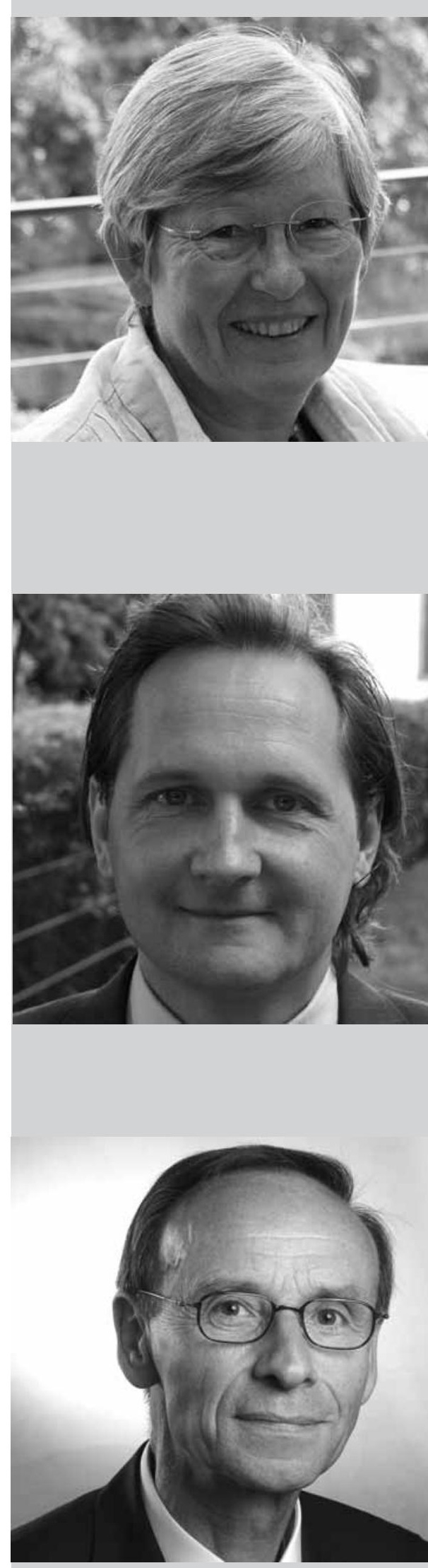


\section{Prof. Dr. Roland Hefendehl}

Roland Hefendehl was born in Freiburg in 1964. He studied law and completed his legal clerkship (Referendariat) in Berlin and Freiburg. He obtained his $\mathrm{PhD}$ and his Habilitation from the University of Munich. From 1999 onwards he was a professor at universities in Berlin and Dresden. Since 2004 he has been Director of the Institute of Criminology and Business Criminal Law at the University of Freiburg. His research interests focus on (business) criminal law, criminology, and crime policy.

\section{Further information:}

http://www.strafrecht-online.org/index.php?scr=hefendehl_science

\section{Prof. Dr. Walter Perron}

Walter Perron is Chair for Criminal Law, Criminal Procedure, and Comparative Criminal Law at the Faculty of Law, University of Freiburg. Walter Perron was born in Worms/Rhein in 1956. He studied law in Mannheim and Freiburg, where he obtained his $\mathrm{PhD}$ and Habilitation. Between 1993 and 2002 he worked at Tübingen, Konstanz, and Mainz Universities. Since 2003 he has been a Professor of Law at the University of Freiburg where he was the Deputy Dean of the Faculty of Law from 2004-2006 and the Dean from 2006-2008. Professor Perron is Deputy Speaker of the International Max Planck Research School for Comparative Criminal Law. His research interests are comparative criminal law and criminal procedural law.

\section{Further information:}

http://www.jura.uni-freiburg.de/institute/perron/

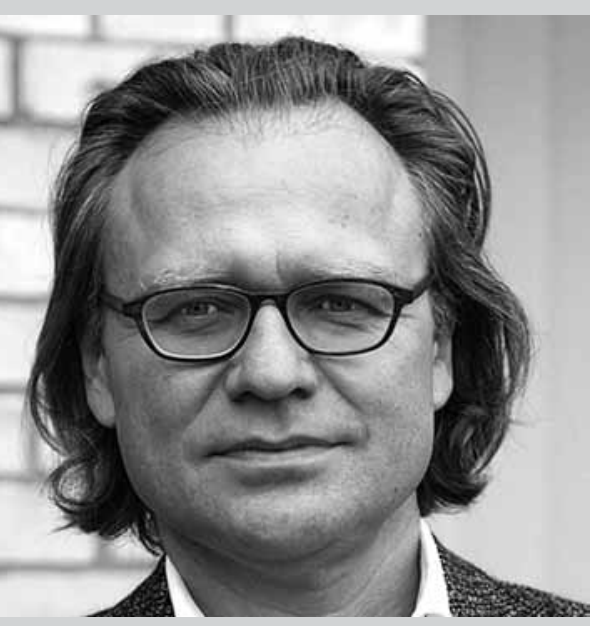

\section{Prof. Dr. Richard Rottenburg}

Richard Rottenburg holds a Chair in Social Anthropology at the Martin-Luther-Universitaet Halle-Wittenberg (Germany) and is a Max Planck Fellow at the Max Planck Institute for Social Anthropology (Halle). His research focuses on the anthropology of law, organizations, science, and technology (LOST). He has written and edited books on the Sudan, on organizations, on economic anthropology, on the transcultural production of objectivity ("Far-Fetched Facts. A Parable of Development Aid," MIT: Cambridge, Mass. 2009), and on theory ("Social and public experiments and new figurations of science and politics in postcolonial Africa." Postcolonial Studies 12 (4): 423-440, 2009).

\section{Further information:}

http://www.ethnologie.uni-halle.de/personal/richard_rottenburg/ 


\section{Prof. Dr. Dr. h.c. mult. Ulrich Sieber}

Prof. Dr. Dr. h.c. mult. Ulrich Sieber is Director at the Max Planck Institute for Foreign and International Criminal Law, Freiburg/Germany. He is a professor and faculty member at the Faculty of Law at the University of Freiburg and the University of Munich, as well as a guest professor at the Renmin University of Beijing, the Beijing Normal University, and the University of Wuhan/ China. He is the President of the German Association for European Criminal Law, a member of the board of directors of the International Association of Penal Law (AIDP), Vice-President of the "Association Internationale pour la Défence Sociale," and the Speaker of the International Max Planck Research School for Comparative Criminal Law in Freiburg.

His main areas of research deal with the changing face of crime, criminal law, and legal policy in today's "global risk society." Major project areas concern comparative criminal law and European criminal law, especially with respect to organized crime, terrorism, economic crime, and cybercrime.

Further information:

http://www.mpicc.de/sieber

\section{Prof. em. Dr. Dr. h.c. mult. Michael Stolleis}

Professor Stolleis was born on July 20, 1941 in Ludwigshafen/Rhine. He studied law and received his doctorate from the University of Munich (1967). He completed his Habilitation in public law, recent legal history, and clerical law at the University of Munich (1973) and was appointed as a professor at the University of Frankfurt (1974). In 1991 he accepted the position of Director and Scientific Member at the Max Planck Institute for European Legal History; since October 2006 he has been an Emeritus Scientific Member at the Institute.

Further information:

http://www.rg.mpg.de/de/personen/michael.stolleis/

\section{Prof. Dr. Dr. h.c. Rüdiger Wolfrum}

Professor Wolfrum (born in 1941) is Professor of Public International Law at the University of Heidelberg and Director of the Max Planck Institute for Comparative Public Law and International Law. Besides his academic activities he was involved in diplomatic negotiations on Law of the Sea and Antarctica. He is a judge at the International Tribunal for the Law of the Sea and served as President from 2005 to 2008.

His academic writings cover a wide range of topics, with a focus on international law in general, Law of the Sea, dispute settlement, the protection of the environment, the United Nations, and human rights.

Further information:

http://www.mpil.de/ww/en/pub/organization/management/directors/wolfrum.cfm
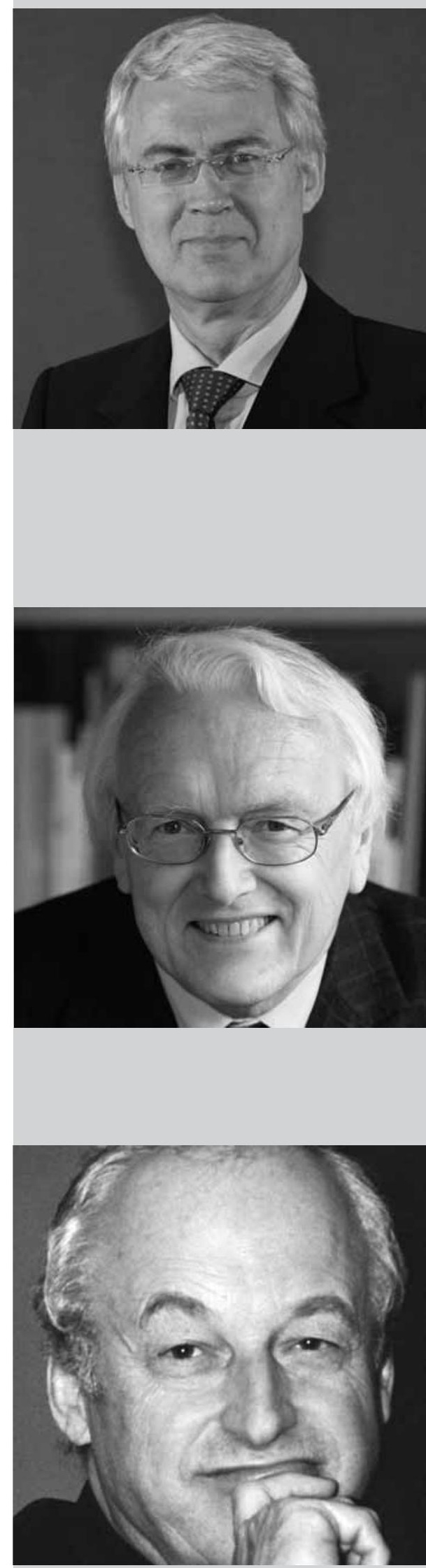


\section{Dr. Michael Kilchling}

Michael Kilchling completed his university studies in law and criminology. In 1995, he was awarded the degree of a doctor juris from the University of Freiburg with his doctoral thesis on "Interests of the victim and public prosecution." Since 1996 he has worked at the Department of Criminology at the Max Planck Institute for Foreign and International Criminal Law; in 1999 he was appointed as a Senior Research Scientist. His main research interests include organized crime, money laundering and the financing of terrorism, confiscation and asset recovery, penal sanctions and sanctioning systems, victim/offender mediation and other forms of restorative justice, victimology, and juvenile justice. Besides his research activities he lectures in different disciplines with a focus on criminal law, criminology, and penology at the University of Freiburg; he also guest lectures abroad. Some of his most recent publications connected to REMEP include: "Victim-Offender Mediation with Juvenile Offenders in Germany," in: A. Mestitz \& S. Ghetti (eds.), Victim-Offender Mediation with Youth Offenders in Europe, Dordrecht 2005, pp. 229- 258; "Restorative Justice Developments in Germany," in: D. Miers \& I. Aertsen (eds.): Regulating Restorative Justice. A comparative study of legislative provisions in European Countries, Frankfurt 2011 (forthcoming).

Further information:

http://www.mpicc.de/ww/en/pub/home/kilchling.htm

\section{Dr. Pietro Sullo}

Pietro Sullo is currently a Research Fellow at the Max Planck Institute for Comparative Public Law and International Law in Heidelberg, Germany and an Adjunct Professor in History of Justice at the Faculty of Law of the Ateneo Federico II in Naples, Italy. Within the Africa Projects of the Max Planck Institute he has worked in Sudan in a capacity-building program aimed at providing local lawyers with legal training. He holds a PhD from the Sant'Anna School of Advanced Studies in Pisa, Italy, where he defended a thesis entitled "Genocide and Transitional Justice in Rwanda: Gacaca Courts and the Search for Truth, Justice and Reconciliation.” Pietro Sullo's main research areas include international human rights and criminal law, transitional justice, and contemporary legal history.

Further information:

http://www.mpil.de/ww/de/pub/organisation/wiss_bereich/psullo.cfm

\section{Dr. Bertram Turner}

Bertram Turner is a Senior Researcher at the Max Planck Institute for Social Anthropology in Halle. He was an academic assistant at the Institute of Social Anthropology and African Studies in Munich between 1993 and 2001 where he taught anthropology with a special focus on religion and legal anthropology. He has held university teaching positions in Munich, Leipzig, and Halle. He has been doing fieldwork in various countries in the Middle East and North Africa, especially in Morocco since 1996 with a specific focus on the management of natural resources, Islamic activism, and conflict settlement in a plural legal setting. His research interests are legal anthropology, conflict studies, anthropology of religion, Islam, and resource management - the main research areas are North and West Africa, the Mediterranean, and the Near East (MENA).

\section{Further information:}

http://www.eth.mpg.de/people/turner/index.html 


\section{University Partnership Declarations}

University of Freiburg

Die Rechtswissenschaftliche Fakultät der

Albert-Ludwigs-Universität Freiburg

(im folgenden „Rechtswissenschaftliche Fakultät der Universität Freiburg“), vertreten durch den Dekan,

und

das Max-Planck-Institut für ausländisches und internationales Strafrecht

(im folgenden "Max-Planck-Institut für Strafrecht"), vertreten durch seine beiden Direktoren,

schließen zur

Regelung der Zusammenarbeit

im Rahmen

der Internationalen Max Planck Research School für Strafrechtsvergleichung

(im folgenden „IMPRS-CC")

und

der International Max Planck Research School on Retaliation, Mediation and Punishment (im folgenden „IMPRS-REMEP")

folgende

Kooperationsvereinbarung 


\section{Präambel}

Die Doktorandenausbildung auf den Gebieten der Strafrechtswissenschaft und Kriminologie wird seit 2007 im Rahmen der IMPRS-CC und der IMPRS-REMEP zwischen der Rechtswissenschaftlichen Fakultät der Universität Freiburg und dem Max-Planck-Institut für Strafrecht kooperativ weiterentwickelt.

Wie zwischen der Rechtswissenschaftliche Fakultät der Universität Freiburg und dem Max-Planck-Institut für Strafrecht (im folgenden „die Partnerinstitutionen") vereinbart (Annex 1), wird zur Regelung der Zusammenarbeit auf dem Gebiet der Doktorandenausbildung zwischen den Partnerinstitutionen die folgende Kooperationsvereinbarung geschiossen:

\section{$\S 1$ Inhalt}

(1) Die Partnerinstitutionen führen gemeinsam zwei Programme zur strukturierten Doktorandenausbildung, IMPRS-CC und IMPRS-REMEP genannt, durch.

(2) Der Inhalt der Zusammenarbeit im Rahmen der IMPRS-CC und der IMPRS-REMEP ergibt sich jeweils aus den Festlegungen zum Gegenstand und zur Art der Kooperation in den Anträgen auf Einrichtung der IMPRS (Annex 2 und 3), den jeweiligen Bewilligungsschreiben (Annex 4 und 5) des Prăsidenten der Max-Planck-Gesellschaft (im folgenden "MPG") und dem von der Hochschulrektorenkonferenz (im folgenden „HRK") mit der MPG erarbeiteten Konzept der International Max Planck Research Schools, beschlossen vom Senat der MPG (März 1999), ergänzt (März 2010) (Annex 6).

\section{$\S 2$ Zweck}

(1) Zweck der Zusammenarbeit zwischen den Partnerinstitutionen im Rahmen der IMPRS-CC und der IMPRS-REMEP, ist es, besonders qualifizierten in- und ausländischen Nachwuchs auf den Gebieten der Strafrechtswissenschaft und Kriminologie für den Wissenschaftsstandort Freiburg zu gewinnen, auszubilden sowie durch eine gezielte Profilbildung einen wissenschaftlichen Mehrwert zu erzielen.

(2) Die Zusammenarbeit erfolgt unter Beachtung der jeweiligen Aufgabenstellungen der Partnerinstitutionen und im Rahmen der für sie jeweils bindenden geltenden rechtlichen Regelungen. Die IMPRS-CC und IMPRS-REMEP haben keine eigene Rechtspersönlichkeit. Sie kooperieren mit anderen Einrichtungen zur Förderung von Forschung und Lehre, können jedoch nicht in ihnen aufgehen. 
(3) Die Partnerinstitutionen treten im Außenverhältnis gegenüber Dritten im eigenen Namen auf.

\section{$\S 3$ Gremien}

(1) Die IMPRS-CC und IMPRS-REMEP werden in wissenschaftlichen Angelegenheiten jeweils durch einen Sprecher vertreten, der ein Wissenschaftliches Mitglied der MPG ist. Der Sprecher vertritt die IMPRS nach außen, bereitet die Sitzungen des Lenkungsausschusses vor und leitet den Lenkungsausschuss. $\mathrm{Er}$ ist insbesondre auch für die Kommunikation mit der MPG zuständig.

(2) Die Sprecher bilden gemeinsam mit den an der Zusammenarbeit beteiligten Vertretern der Partnerinstitutionen den Lenkungsausschuss. Am Lenkungsausschuss der IMPRS-REMEP sind auch die an der überörtlichen Zusammenarbeit beteiligten Vertreter anderer Universitäten und Max-Planck-Institute beteiligt. Der Lenkungsausschuss trifft alle für den Betrieb der IMPRS-CC und IMPRS-REMEP notwendigen grundsätzlichen Sachentscheidungen, insbesondere hinsichtlich des Aufnahmeverfahrens, der Bewilligung des Vorhabensprojekts, des Ausbildungsprogramms sowie der Evaluation der Doktoranden und ihrer Forschungsarbeit. Einzelentscheidungen werden von dem Sprecher im schriftlichen Beschlussverfahren getroffen.

(3) Die Sprecher der IMPRS-CC und IMPRS-REMEP werden jeweils durch einen Koordinator unterstützt. Der Koordinator organisiert den Betrieb der IMPRS-CC und IMPRSREMEP. Er ist für die Umsetzung der Beschlüsse des Lenkungsausschusses und des Sprechers verantwortlich. Der Verantwortungsbereich beinhaltet insbesondere die Koordination des Ausbildungsprogramms, der Außendarstellung und Ausschreibungsmaßnahmen der IMPRS-CC und IMPRS-REMEP.

\section{$\S 4$ Promotion}

(1) Das Promotionsrecht liegt bei der Rechtswissenschaftlichen Fakultät der Universität Freiburg. Näheres regelt die Promotionsordnung der Rechtswissenschaftlichen Fakultät (nachfolgend: Promotionsordnung).

(2) Die Aufnahmeentscheidung eines Doktoranden in die IMPRS-CC oder IMPRSREMEP gilt als Nachweis eines besonderen fachlichen Interesses i.S.v. § 6 Absatz 3 Ziffer e) Promotionsordinung.

(3) Die Promotionsurkunde wird von der Universität Freiburg ausgehändigt. Der Sachverhalt der Promotion im Rahmen des Ausbildungsprogramms der IMPRS-CC bzw. IMPRS-REMEP wird durch das Max-Planck-Logo (Minerva) und die zusătzliche Unterschrift des Sprechers gekennzeichnet. 
(4) Eine Promotion kann auch in gemeinsamer Betreuung mit einer ausländischen Universität durchgeführt werden. Absatz 3 gilt entsprechend.

\section{§ 5 Teilnahme}

(1) Mindestens die Hälfte der Teilnehmer an dem Ausbildungsprogramm sollen auslândische Doktoranden sein.

(2) Die Doktoranden werden durch internationale Ausschreibung gewonnen und intensiv in den Wissenschaftsbetrieb vor Ort integriert.

(3) Teilnahmebedingung ist, dass der Doktorand die Promotionsvoraussetzungen der Rechtswissenschaftlichen Fakultăt der Universităt Freiburg erfüllt und vom Lenkungsausschuss aufgenommen wird. Für den Fall der Promotion an einer ausländischen Universităt sind die Promotionsvoraussetzungen dieser Universität zu erfüllen.

(4) Die Teilnahme an dem Ausbildungsprogramm wird nach Abschluss der Promotion durch eine Bescheinigung bestätigt (im folgenden "Teilnahmebescheinigung"), die von durch eine Bescheinigung bestätigt (im folgenden "Teilnahmebescheinigung"), die von
dem Sprecher der IMPRS-CC bzw. IMPRS-REMEP und dem Dekan der Rechtswissenschaftlichen Fakultät der Universităt Freiburg unterschrieben wird (Annex 7). Für den Fall der Promotion an einer ausländischen Universităt wird die Teilnahmebescheinigung von dem Sprecher der IMPRS-CC bzw. IMPRS-REMEP und dem Vertreter dieser Universität unterschrieben.

\section{$\S 6$ Betreuung}

(1) Die Doktoranden sollen eine gründliche wissenschaftliche Ausbildung genießen und dabei möglichst zügig zum Abschluss einer exzellenten Promotion geführt werden. Deswegen sollen die Doktoranden intensiv betreut werden. Intensive Betreuung beinhaltet, dass die Doktoranden mehr als einen wissenschaftlichen Ansprechpartner haben oder Thesis Committees eingesetzt werden.

(2) Die Partnerinstitutionen tragen dafür Sorge, dass die Doktoranden den im Ausbildungsprogramm vorgesehenen Verpflichtungen nachkommen und für verbindliche Veranstaltungen freigestellt werden.

(3) Die Partner verpflichten sich, ihre Doktoranden besonders auf die Pflichten und Regelungen zur Sicherung guter wissenschaftlicher Praxis hinzuweisen

(4) Einzelheiten bestimmt der Lenkungsausschuss. 


\section{$\S 7$ Begutachtung}

(1) Die IMPRS-CC und IMPRS-REMEP werden nach Ablauf von spätestens vier Jahren nach Beginn des Ausbildungsprogramms jeweils durch die von der MPG und der HRK eingesetzte Auswahlkommission begutachtet.

(2) Die IMPRS-CC und IMPRS-REMEP legen zum Zweck der Begutachtung drei bis vier Jahren nach Beginn des Ausbildungsprogramms jeweils einen Zwischenbericht vor, der den Stand des Programms darstellt.

\section{$\S 8$ Laufzeit}

(1) Die Laufzeit der IMPRS-CC und IMPRS-REMEP beläuft sich auf einen Zeitraum von zunächst sechs Jahren seit Beginn des Ausbildungsprogramms. Bei positiver Begutachtung ist auf Antrag eine Verlängerung der IMPRS-CC bzw. IMPRS-REMEP um sechs Jahre möglich.

(2) Der Verlängerungsantrag soll eine Erklärung der Rechtswissenschaftlichen Fakultắt der Universität Freiburg beinhalten, dass die Fakultät grundsätzlich weiter als Partner der IMPRS-CC bzw. IMPRS-REMEP zur Verfugung steht.

\section{§ 9 Leistungen}

(1) Jede Partnerinstitution beteiligt sich mit den auf ihrer Seite entsprechend den bewilligten Anträgen für die Durchführung der IMPRS-CC und IMPRS-REMEP notwendigen Personal- und Sachleistungen. Weiter werden durch die MPG die von ihrem Präsidenten bewilligten zusätzlichen Ressourcen für Zwecke der IMPRS zur Verfügung gestellt (Annex 4 und 5). Die Mittel werden von den Partnern getrennt nach den für sie geltenden Regelungen bewirtschaftet und nachgewiesen.

(2) Die an der Zusammenarbeit beteiligten Vertreter der Partnerinstitutionen nehmen insbesondere an der Auswahl und Betreuung der Doktoranden, gemeinsamen wissenschaftlichen und nichtwissenschaftlichen Veranstaltungen und dem Begutachtungsverfahren der IMPRS-CC und IMPRS-REMEP teil.

(3) Persönliche Geld- oder Sachentschädigungen zwischen den Vertragspartnern werden im Rahmen des Projekts nicht gezahlt. Die Direktoren des Max-Planck-Instituts können bis zu zwei Semesterstunden Vorlesung als Teil ihrer Tätigkeit im Max-PlanckInstitut für die allgemeine universitäre Ausbildung erbringen.

(4) Die Zahlung von Stipendien oder Gehältern an die Promovenden erfolgt nach den jeweils güitigen Richtlinien der Partner. Eine einheitliche Gestaltung ist anzustreben. 


\section{$\S 10$ Betriebliche Ordnung}

Die Doktoranden der IMPRS-CC und IMPRS-REMEP unterliegen während ihrer Tătigkeit in den Einrichtungen der Partnerinstitution den dortigen ordnungs- und sicherheitsrechtlichen Bestimmungen, unbeschadet ihrer sonstigen dienst- und arbeitsrechtichen Beziehungen.

\section{$\S 11$ Haftung}

(1) Für Sach- und Vermögensschäden, die im Rahmen der Durchführung der IMPRSCC und IMPRS-REMEP bzw. dieser Vereinbarung entstehen, haftet diejenige Partnerinstitution, der die Schadensursache und/oder der Schadensverursacher betrieblich zuzuordnen ist, je nach Sachlage auch beide Vertragspartner im angemessenen Verhältnis gemeinsam.

(2) Die Haftung wird im Verhăltnis zwischen den Partnerinstitutionen auf Vorsatz und grobe Fahrlässigkeit beschränkt.

(3) Von Ersatzansprũchen Dritter stellen sich die Partnerinstitutionen nach den vorstehenden Grundsätzen ohne Beschränkung auf ein Maß des Verschuldens wechselseitig frei.

(4) Die Partnerinstitutionen haften nicht für Schåden, die daraus entstehen können, dass ihre Forschungseinrichtungen nicht oder nicht im vorgesehenen Umfang aufrecht erhalten werden können bzw. ihr Betrieb aufgrund behördlicher Auflagen eingeschränkt oder eingestellt werden muss

(5) Bei Personenschäden gelten die gesetzlichen Bestimmungen.

\section{$\S 12$ Vertraulichkeit}

(1) Die Partnerinstitution behandelt alle Angelegenheiten der anderen Partnerinstitution vertraulich, die ihr im Rahmen der Zusammenarbeit bekannt werden und die als vertraulich erkennbar oder bezeichnet sind.

(2) Die aus der Aus- und Durchführung dieser Kooperationsvereinbarung anfallenden personenbezogenen Daten werden von den Partnerinstitutionen nur zum vereinbarungsgemäßen Gebrauch verwendet. 


\section{$\S 13$ Kündigung}

Diese Kooperationsvereinbarung kann erstmals nach fünf Jahren seit Beginn des Ausbildungsprogramms gekündigt werden. Die Kündigungsfrist beträgt zwölf (12) Monate. Ein ordnungsgemäßer Abschluss aller Doktorarbeiten ist - ggf. auch über die formale Beendigung der IMPRS hinaus - sicherzustellen.

\section{$\S 14$ Inkrafttreten und Geltungsdauer}

Diese Kooperationsvereinbarung tritt durch Unterzeichnung in Kraft und gilt für die Laufzeit der IMPRS-CC und IMPRS-REMEP.

\section{$\S 15$ Wirksamkeit}

Sollten einzelne Regelungen dieser Kooperationsvereinbarung gegen das Landes- oder Hochschulrecht verstoßen, bleibt die Kooperationsvereinbarung als Ganzes wirksam. Die Partnerinstitutionen ersetzen die unwirksamen Regelungen durch solche, deren Inhalt dem Sinn des ursprünglich Geregelten möglichst nahe kommt.

\section{$\S 16$ Änderungen}

Änderungen dieser Kooperationsvereinbarung bedürfen der Schriftform. Dies gilt auch für die Änderung des Schriftformerfordernisses selbst.

Freiburg, den $14+2010$

Max-Planck-Institut für ausländisches und internationales Strafrecht

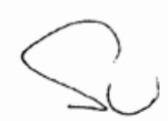

Prof. Dr. Dr. h.c. Ulrich

\section{8 .2010}

Rechtswissenschaftliche Fakultät der Albert-Ludwigs-Universität Freiburg

$$
\text { ( }
$$

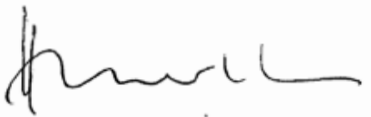

Prof. Dr. Hanno Merkt LL.M. 


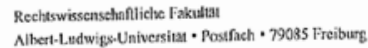

\section{Herm}

Prof. Dr. Dr. h.c. Ulich Sieber

Max-Plack-Institut für auslandisches und

internationales Strafrecht

Hauspost

IMPRS-Kooperationsvereinbarung zwischen der Universităt Freiburg und der Max-Planck-Gesellschaft

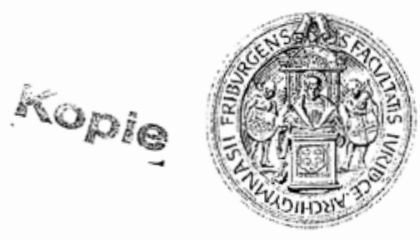

\section{Lieber Herr Kollege Sieber,}

wie von Ihnen gewünscht sende ich Ihnen in der Anlage die unterschriebene Kooperationsvereinbarung für die beiden Research Schools. Kooperationsvereinbarung für die beiden Research Schools.

Mit den besten Grußen Fakultăt

Dekanat

Albert-Ludwigs-Universität Freiburg

Prof. Dr. Hanno Merk, LL.M.
Dekan

Platz der Atten Syragoge Kolegiengebatude II Raum 2105

Tel. $0761 / 203-2141$
Fax 0761/203-2137

dekanatgara.uni-rraburg.de wwwe, jura unifteturg deddekana

Froburg. 25.03.2010
Rechtswissenschaftliche

Anlagen: 2 Exemplare Kooperationsvereinbarung 


\section{Martin Luther University Halle-Wittenberg}

\section{International Max Planck Research School on Retaliation, Mediations and Punishment}

\section{Partnership Declaration} of the participating University

1. Titel of the International Max Planck Research School: International Max Planck Research School on Retaliation, Mediations and Punishment

2. Applicants: Max Planck Institute for Foreign and International Criminal Law, Max Planck Institute for Social Anthropology, Max Planck Institute for Comparative Public Law and International Law, Max Planck Institute for European Legal History

3. Partner University: Martin-Luther-Universität Halle Wittenberg legal representative: Rector, Prof. Dr. Udo Sträter address: $\quad$ Universitätsplatz 10, 06108 Halle

Tel., Fax, email: $\quad$ +493455521000,+49345 5527075, rektor@uni-halle.de

4. Contribution: The Martin-Luther-Universität Halle-Wittenberg supports the prolongation of the IMPRS REMEP. The MLU will do this through its research focus "Society and Culture in Motion" and the affiliated Graduate School. It will provide open access to the qualification program of the International Graduate Academy for the PhD-candidates. Since the MLU does not have a stipend programme, though, it will support the allocation of two stipends as far as third party funding will be available.

5. Contributing Institution: University Research Focus "Society and Culture in Motion" of the MLU, Legal Representative: Richard Rottenburg, Reichardtstrasse 11, 06114 Halle, email: <richard.rottenburg@ethnologie.uni-halle.de>.

Halle, 09. Januar 2012
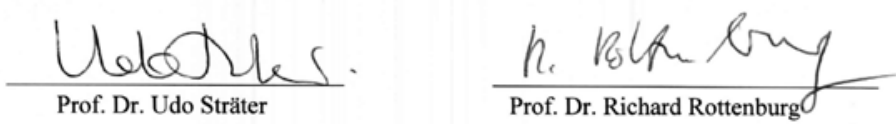



\section{Program: Conference on Retaliation}

\section{1 웅중}

International

Max Planck Research School on

Retaliation, Mediation and Punishment

\section{Conference on Retaliation}

Introduction

The Concept of Retaliation in the REMEP Research Design

In the research outline of the International Max Planck Research School on Retaliation, Mediation and Punishment (IMPRS REMEP), the concept of retaliation, which is based on the overall principle of reciprocity, refers broadly to the full range of reactions to circumstances that are perceived to be deviant or socially transgressive. Such a constellation presupposes two opposed, nominally equal parties. Understood in this sense, retaliation occurs at all levels of socio-political organization, from nuclear families to nation states and transnational organizations. Retaliatory reactions run the whole gamut of conflict resolution procedures from consensual settlement via various forms of compensation to violent reprisal and escalation.

Taking this conception of retaliation as our point of departure, we have assumed in our shared research design that the propensity to react violently decreases as social proximity between the parties involved is established or becomes more pronounced. Further significant variables include power differentials among conflicting parties and the institutional arrangements balancing such differentials.

Hence, the propensity to regulate conflict through retaliation, without the intervention of central political authorities or other third parties endowed with power, appears to be characteristic of opposed or at least distinguishable groupings with an intermediate degree of socio-political proximity. The parties must be close enough to each other to share the desire to keep third parties out (this applies especially to "higher" levels of administrative or political organization) and distant enough from one another for violent retaliation to remain a viable option (because without this threat there is no incentive to opt for compensation).

The concept of retaliation, however, also materializes in various conflict scenarios in which central political authorities, states, global governance institutions, and transnational organizations of all kinds (social movements, faith-based organizations, INGOs, etc.) appear as active parties or are opposed to parties that are organized according to different, less complex principles. In such cases, nominal equality may be a contested issue, although it does not necessarily imply a balance of power. Thus, the REMEP research agenda incorporates the analysis of both constellations in which power differentials are reduced or absent and constellations in which these variables come into play in various ways.

\section{Conceptual Framework of the Conference}

The conference will be divided into the following two parts.

\section{Approaches to and perspectives on retaliation}

With reference to recent interest in the principle of retaliation in a number of human sciences, members of REMEP faculty and invited experts representing the disciplines cooperating in the REMEP program will present an inventory of the basic approaches to 'retaliation' and the most recent theoretically informed and innovative research perspectives on this subject. Reflections on basic theorizing with regard to retaliation will also address the various and not always compatible concepts of order which appear to be fundamental to the disciplines united in REMEP. 
2. Further elaborations on the concept of retaliation - transdisciplinary perspectives

It would be worthwhile, we suggest, to elaborate on the concept of retaliation and to broaden our perspective in a transdisciplinary effort. Analyzing recent developments without neglecting the historical perspective, our aim is to achieve an upgraded, theoretically informed empirical understanding of the concepts and themes we addressed in the original version of the REMEP program.

Taking this transdisciplinary convergence as common ground, we are particularly interested in scalar arrangements and in the interface between, first, local variability in the ways in which retaliation informs processes of conflict settlement and, second, references to retaliation as a universal normative template at a transnational scale. Recent interventions in arenas of conflict that are affected by transscale entanglements have put discourse on retaliation back on the transnational agenda. In this context, it will be asked how the various normative registers that are inscribed in the nomosphere deal with concrete situations and moments of retaliation.

\section{Format of the Conference}

Introduction

Panel 1: Retaliation and the Human Nature: The search for universalities?

Panel 2: Faith-based Retaliation: Spirituality and normativity of the retaliatory grammar

Panel 3: Retaliation in Negotiations and Organizations of Social and Political Orders

Panel 4: Retaliation and the Social Construction of Crime and Deviance

Panel 5: International Law, Travelling Models of Retaliation, Translations

Final Discussion

Wednesday, 26 October $2011 \quad$ Arrival

19:00 Informal get-together

Thursday, 27 October 2011

\begin{tabular}{l|l}
$8: 30-8: 45$ & Registration \\
$8: 45-9: 00$ & Welcome Addresses
\end{tabular}

Hans-Jörg Albrecht, MPI for Foreign and International Criminal Law, Freiburg

Günther Schlee, MPI for Social Anthropology, Halle

Carolin Hillemanns, MPI for Foreign and International Criminal Law, Freiburg

\section{Introduction}

Chair: Keebet v. Benda-Beckmann, MPI for Social Anthropology, Halle

\begin{tabular}{c|l}
$9: 00-10: 00$ & $\begin{array}{l}\text { Introduction to the conference: } \\
\text { On Retaliation: Conceptual Plurality, Transdisciplinary Research, } \\
\text { Rifts and Translations } \\
\text { Bertram Turner, MPI for Social Anthropology, Halle }\end{array}$ \\
\hline $10: 00-10: 30$ & $\begin{array}{l}\text { Coffee Break } \\
.12\end{array}$
\end{tabular}


Thursday, 27 October 2011 cont.

\section{Panel 1A: Retaliation and the Human Nature: The search for universalities?}

Chair: Csaba Györy, MPI for Foreign and International Criminal Law, Freiburg

\begin{tabular}{|l|l}
\hline $10: 30-11: 15$ & $\begin{array}{l}\text { Violence, Retaliation and Illicit Markets } \\
\text { Hans-Jörg Albrecht, MPI for Foreign and International Criminal Law, } \\
\text { Freiburg }\end{array}$ \\
\hdashline $11: 15-12: 00$ & $\begin{array}{l}\text { Individual and Social Functions of Revenge: A justice-based approach } \\
\text { Mario Gollwitzer, University of Marburg }\end{array}$ \\
\hline $12: 00-13: 30$ & \begin{tabular}{l} 
Lunch Break \\
\hline
\end{tabular}
\end{tabular}

Panel 1B: Retaliation and the Human Nature: The search for universalities?

Chair: Stefanie Bognitz, MPI for Social Anthropology, Halle

\begin{tabular}{|c|c|}
\hline $13: 30-14: 15$ & $\begin{array}{l}\text { From Retaliation to Genocide. On Shame and Humiliation } \\
\text { as Clues for Understanding "Ethnic” Conflict in Rwanda } \\
\text { Axel Paul, University of Siegen }\end{array}$ \\
\hline $14: 15-15: 00$ & $\begin{array}{l}\text { In the Heat of the Moment: The influence of visceral factors on } \\
\text { retaliation } \\
\text { Thomas M. Tripp, Washington State University Vancouver, } \\
\text { co-authored by Robert J. Bies, Georgetown University }\end{array}$ \\
\hline $15: 00-15: 30$ & Coffee Break \\
\hline Panel 2A: & $\begin{array}{l}\text { h-based Retaliation: Spirituality and normativity of the } \\
\text { aliatory grammar }\end{array}$ \\
\hline \multicolumn{2}{|c|}{ Chair: Thomas Walter, MPI for European Legal History, Frankfurt } \\
\hline $15: 30-16: 15$ & $\begin{array}{l}\text { Nemesis. A glimpse into Christian motives of punishment in the } \\
\text { course of time } \\
\text { Mathias Schmoeckel, University of Bonn }\end{array}$ \\
\hline $16: 15-17: 00$ & $\begin{array}{l}\text { Where Official Justice Ends, Theodicy Begins: 'Curse paranoia' and } \\
\text { the rise of retaliatory shamanism in Tuva (Siberia) } \\
\text { Konstantinos Zorbas, Cambridge University }\end{array}$ \\
\hline $18: 30$ & Informal get-together \\
\hline
\end{tabular}




\begin{tabular}{|l|l|} 
Friday, 28 October 2011 & $\begin{array}{l}\text { Faith-based Retaliation: Spirituality and normativity of the } \\
\text { retaliatory grammar }\end{array}$ \\
\hdashline Chair: Fazil Moradi, MPI for Social Anthropology, Halle & $\begin{array}{l}\text { Crimes and punishments: Intentionality and diya (blood money) in } \\
\text { Algeria and Sudan } \\
\text { Yazid Ben Hounet, Lécole des Hautes Etudes en Sciences Sociales, Paris }\end{array}$ \\
\hdashline $9: 00-9: 45$ & $\begin{array}{l}\text { A threatened order? Disputing and magical retaliation in the } \\
\text { South African lowveld } \\
\text { Severin Lenart, MPI for Social Anthropology, Halle }\end{array}$ \\
\hdashline $10: 30-11: 00$ & \begin{tabular}{l} 
Coffee Break \\
\hdashline
\end{tabular}
\end{tabular}

\section{Panel 3A: $\quad$ Retaliation in Negotiations and Organizations of Social and Political Orders}

Chair: Julia Kasselt, MPI for Foreign and International Criminal Law, Freiburg

\begin{tabular}{|c|c|}
\hline $11: 00-11: 45$ & $\begin{array}{l}\text { Retaliation; Compensation and Sharia: What affects legal options? } \\
\text { Examples from Somalia and the Sudan } \\
\text { Günther Schlee, MPI for Social Anthropology, Halle }\end{array}$ \\
\hline $11: 45-12: 30$ & $\begin{array}{l}\text { Practices of Retaliation in Disputes over Cattle: An analysis of the role } \\
\text { of cattle in retaliation discourses } \\
\text { Ab Drent, MPI for Social Anthropology, Halle }\end{array}$ \\
\hline $12: 30-14: 00$ & Lunch Break \\
\hline
\end{tabular}

Panel 3B: $\quad$ Retaliation in Negotiations and Organizations of Social and Political Orders

Chair: Carolijn Terwindt, MPI for Foreign and International Criminal Law, Freiburg

\begin{tabular}{l|l}
$14: 00-14: 45$ & $\begin{array}{l}\text { Explaining the World through Retaliation, or: Why the wars did not } \\
\text { end in dispute management }\end{array}$ \\
Friederike Stahlmann, MPI for Social Anthropology, Halle
\end{tabular}

\section{Panel 4A: Retaliation and the Social Construction of Crime and Deviance}

Chair: Johanna Mugler, MPI for Social Anthropology, Halle

14:45-15:30 Violence and Retaliation in the Legal Practice of Criminal Justice between the 17th and 19th Century

Karl Härter, MPI for European Legal History 


\begin{tabular}{|c|c|}
\hline \multicolumn{2}{|c|}{ Friday, 28 October $2011 \quad$ cont. } \\
\hline $15: 30-16: 00$ & Coffee Break \\
\hline $16: 00-16: 45$ & $\begin{array}{l}\text { Crime in Motion: Predation, Retaliation, and the Spread of } \\
\text { Urban Violence } \\
\text { Richard Wright, University of Missouri - St. Louis; co-authored by } \\
\text { Volkan Topalli, Georgia State University, Scott Jacques, University of } \\
\text { Cincinnati }\end{array}$ \\
\hline \multicolumn{2}{|c|}{ Saturday, 29 October 2011} \\
\hline $\begin{array}{l}\text { Panel 4B: } \\
\text { Chair: Kerrin-Si }\end{array}$ & $\begin{array}{l}\text { Petaliation and the Social Construction of Crime and Deviance } \\
\text { Arfsten, MPI for Foreign and International Criminal Law, Freiburg }\end{array}$ \\
\hline $9: 00-9: 45$ & $\begin{array}{l}\text { A Criminal is a Victim is a Criminal? An Economic Approach to the } \\
\text { Victim-Offender Overlap } \\
\text { Horst Entorf, University of Frankfurt }\end{array}$ \\
\hline $9: 45-10: 30$ & $\begin{array}{l}\text { Laypersons' Reactions towards Deviancy are Mainly Determined by } \\
\text { Retributive Motives } \\
\text { Margit Oswald, University of Bern }\end{array}$ \\
\hline $10: 30-11: 00$ & Coffee Break \\
\hline $\begin{array}{l}\text { Panel 5A: } \\
\text { Chair: Adepeju }\end{array}$ & $\begin{array}{l}\text { ernational Law, Travelling Models of Retaliation, Translations } \\
\text { rin, MPI for Foreign and International Criminal Law, Freiburg }\end{array}$ \\
\hline $11: 00-11: 45$ & $\begin{array}{l}\text { Juridical Dimensions of Retaliation in the Doctrine of the } \\
\text { Early Modern Period between Criminal and International Law } \\
\text { Massimo Meccarelli, Università di Macerata }\end{array}$ \\
\hline $11: 45-12: 30$ & $\begin{array}{l}\text { Retaliation in Transitional Justice Scenarios: The case of Uruguay, } \\
\text { Argentina and Colombia } \\
\text { Gustavo Rojas Paez, MPI for Foreign and International Criminal Law, } \\
\text { Freiburg }\end{array}$ \\
\hline $12: 30-14: 00$ & Lunch Break \\
\hline
\end{tabular}


Saturday, 29 October 2011 cont.

\section{Panel 5B: International Law, Travelling Models of Retaliation, Translations}

Chair: Nathan Muwereza, MPI for Foreign and International Criminal Law, Freiburg

\begin{tabular}{|c|l}
\hline $14: 00-14: 45$ & $\begin{array}{l}\text { The ICC Reparation System } \\
\text { Pietro Sullo, MPI for Comparative Public Law and International Law, } \\
\text { Heidelberg }\end{array}$ \\
\hdashline $14: 45-15: 30$ & $\begin{array}{l}\text { Retaliation in a Globalizing World: Assessing the normative dimensions } \\
\text { of necropolitics } \\
\text { Shakira Bedoya Sánchez, MPI for Foreign and International Criminal } \\
\text { Law, Freiburg }\end{array}$ \\
\hdashline $15: 30-17: 00$ & $\begin{array}{l}\text { Final Discussion } \\
\text { Chair: Franz v. Benda-Beckmann, MPI for Social Anthropology, Halle }\end{array}$
\end{tabular}




\section{Application Requirements}

1. For the IMPRS REMEP at the Max Planck Institute for Foreign and International Criminal Law in cooperation with the Albert-Ludwigs-University, Freiburg, for research within the area of criminology, criminal law and sociology for the the conferral of a doctorate degree in law (Dr. jur.) and sociology (Dr. phil.):

1a. Completion of a law degree at a German university or completion at an equivalent university abroad. First or Second German State Law Exam with a minimum overall grade of "vollbefriedigend" (according to the examination regulations "JAPrO" of the State of Baden-Württemberg), or an equivalent degree with an equivalent grade ("with distinction") from abroad.

1b. Alternatively, completion of a regular university studies in social sciences with an overall duration of at least 4 years at a German or equivalent university from abroad. Master degree in sociology as major subject, or equivalent degree from Germany or abroad.

2. For the IMPRS REMEP at the Max Planck Institute for Comparative Public Law and International Law, Heidelberg, for research within the area of international law for the conferral of a doctorate degree in law (Dr. jur.):

2a. Completion of a law degree at a German university or completion at an equivalent university abroad. First or Second German State Law Exam with a minimum overall grade of "vollbefriedigend" (according to the examination regulations "JAPrO" of the State of Baden-Württemberg), or an equivalent degree with an equivalent grade ("with distinction") from abroad.

3. For the IMPRS REMEP at the Max Planck Institute for European Legal History in co-operation with the Johann Wolfgang Goethe-Universität, Frankfurt/ Main, for research within the areas of Legal History and Early Modern/Modern History for the conferral of a doctorate degree in law (Dr. jur.) or sociology (Dr. phil.):

3a. Completion of a law degree at a German university or completion at an equivalent university abroad. First or Second German State Law Exam with a minimum overall grade of "vollbefriedigend" (according to the examination regulations "JAPrO" of the State of BadenWürttemberg), or an equivalent degree with an equivalent grade (“with distinction”) from abroad.

3b. Alternatively, completion of a regular university studies in social sciences with sociology as major subject (and dissertation subject), a second major subject, and two additional minor subjects, with an overall duration of at least 4 years at a German university, or completion of an equivalent programme at an equivalent university abroad. Master degree or State Exam for second school level teachers ("Lehramt an Gymnasien"), or equivalent degree from abroad.
4. For the IMPRS REMEP at the Max Planck Institute for Social Anthropology in co-operation with the Martin-Luther-University Halle-Wittenberg for research within the areas of Anthropology of Law and Conflict Studies for the conferral of a doctorate degree in Social Anthropology (Dr. phil.):

4a. Completion of a university degree in social anthropology at a German university or completion at an equivalent university abroad.

4b. Alternatively to (4a.), completion of regular university studies in a social sciences' discipline as major subject, a second major subject, or two additional minor subjects, with an overall duration of at least 4 years at a German university, or completion of an equivalent programme at an equivalent university abroad. Master degree or equivalent degree from abroad. In exceptional cases with a background in sociology of law and interest in social anthropology empirical research, completion of a law degree at a German university or completion at an equivalent university abroad. First or Second German State Law Exam with a minimum overall grade of "vollbefriedigend" (according to the examination regulations "JAPrO" of the State of Baden-Württemberg), or an equivalent degree with an equivalent grade ("with distinction") from abroad.

5. Submission of a substantive proposal for a dissertation topic linked to the research agenda of the IMPRS REMEP.

6. Solid proficiency in the English language. In addition, students should have at least some basic knowledge of German language and demonstrate willingness to improve it.

The IMPRS REMEP seeks to reach a composition of at least 50 percent foreign doctoral students. Thus, foreign candidates with a foreign degree are explicitly encouraged to apply. Recognition of equivalence of foreign degrees is to be determined by the doctoral committee of the respective Faculty or by the respective examination committee, in accordance with the criteria laid out by the Central Office for Foreign Education at the Secretariat of the Standing Conference of the Ministers of Education and Cultural Affairs ("Zentralstelle für ausländisches Bildungswesen im Sekretariat der Ständigen Konferenz der Kultusminister der Länder").

\section{Application documents}

1. Cover sheet addressed to the 'International Max Planck Research School on Retaliation, Mediation, Punishment' at the Max Planck Institute for Foreign and International Criminal Law in Freiburg i.Br.

2. European style curriculum vitae (http://europass.cedefop.europa.eu/) in German or English. It should include information on all previous research activities.

3. Copy of Secondary Education certificate with a list of subject areas. The documents must be 
officially translated into German (preferably) or English and a copy of the original supplied.

4. Copy of certificates relating to the First and, where applicable, Second German State Law Exam(s) from lawyers or certificates relating to the University or State Exam from social scientists. From foreign graduates, copy of all university certificates with a list of all grades, including the overall grade, the average grade and the university certificate of graduation. The documents must be officially translated into German (preferably) or English and a copy of the original supplied.

5. Substantive/meaningful proposal for a research topic (5 pages), preferably in English, structured into a) relevance of the proposed topic in the context of the overall research agenda of the IMPRS REMEP, b) state of preparation, c) aim of the project, d) probable links to other disciplines, e) methodology, f) proposed timeline, g) intended time of completion of the dissertation. It is intended that doctoral students, when participating in the research program in a regular manner, will be able to complete the program within a two year period.

6. Two letters of recommendation from two senior scientists (to be written in English or German). These letters should include information as to previous research experience, and vouch for the ability of the applicant to undertake doctoral studies at the Research School.

7. Applicants who do not speak English as their native language and who are unable of demonstrating good proficiency in English language in any other way must prove their skills through language examination certificates. In particular, the International English Language Testing System (IELTS) with at least 6.0 bands or TOEFEL (at least 560 points, computer: 220 points) are recognized.

8. Applicants who do not speak German as their native language should be capable to demonstrate basic knowledge of German, e.g., through a certificate German language ("Zertifikat Deutsch", $Z D)$. Proficiency in German language is not a formal precondition for application. However, subject to university regulations, German is mandatory at some universities for the final oral doctoral exam in sociology, social anthropology and law. If necessary, access to external language courses can be arranged.

Presentation of officially authenticated copies of the original certificates etc., with regards to Nos. 3 and 4 above, is only necessary once a decision has been made to admission.

\section{Application dates and further details}

Please visit

http://www.remep.mpg.de/en/application.htm
Application documents must be submitted electronically to the following email address: imprs-remep@ mpicc.de (maximum 5 MB per E-Mail). Please refrain from sending postal applications.

Applicants will be invited to telephone or personal interviews or videoconferences in Freiburg upon prior notification. The applicants will be informed of the selection results in writing. During the selection procedure we ask applicants to refrain from contacting the Institute with regards to the results of the procedure. An absolute right to financial support does not exist. The Max Planck Society endeavors, wherever possible, to employ disabled persons and applications from such persons are expressly called for. The Max Planck Society also desires to increase the proportion of women in areas where they are underrepresented. Women are therefore expressly encouraged to apply.

\section{Financial support}

Financial support is granted in accordance with the guidelines of the Max Planck Society in the form of a doctoral contract or bursary. The financial support regarding the doctoral contract corresponds with public service organizations (up to 50 per cent of the payment group 13 degree 1 of the General Framework Agreement on Public Services, "Tarifvertrag Öffentlicher Dienst", TVöD). Financial support will be granted for a period of two years, with a possibility of two subsequent extensions, each for a duration of six months.

\section{Inquiries}

Further information on the research program of the IMPRS REMEP can be found at http://www.remep.mpg.de

For additional inquiries, please write to imprs-remep@mpicc.de.

\section{Contact Address}

Dr. Carolin F. Hillemanns

Max Planck Institute for Foreign and

International Criminal Law

Günterstalstraße 73

79100 Freiburg i. Br.

Germany

Tel.: +49 (761) 7081-250

Fax: +49 (761) 7081-316

c.hillemanns@mpicc.de

For further information regarding the International Max Planck Research Schools visit http://www.mpg.de/en/imprs 


\section{IMPRINT}

\section{Herausgeber}

Max-Planck-Gesellschaft zur

Förderung der Wissenschaften e.V.

c/o Max-Planck-Institut für ausländisches

und internationales Strafrecht

Geschäftsführender Direktor 201 1/2012

Prof. Dr. Dr. h.c. mult. Ulrich Sieber

Günterstalstraße 73

D-79100 Freiburg

Tel.: +49 (0)761-7081-0

Fax: +49 (0)761-7081-294

E-Mail: info@mpicc.de

Internet: http://www.mpicc.de

\section{Druck}

Stückle Druck und Verlag

Stückle-Straße 1

77955 Ettenheim

\section{Gesamtredaktion}

Dr. Carolin Hillemanns

\section{Satz}

Beate Lickert

\section{Bildnachweise}

Umschlagbild: Justitia - Frank Schmidt, Köln.

Silhouette hinter Gittern - Mit freundlicher Genehmigung der WDR-Internet-Redaktion Köln.

Kenya-Justice Vital to Stability/HRW Photo Galleries - (C) 2007 Noor Khamis. ICTY Judges - Mit freundlicher Genehmigung des Press Office ICTY, Den Haag.

Portraitfotos wurden von den jeweils abgebildeten Personen zur Verfügung gestellt.

\section{Gestaltung}

Lavout und Titelbild:

Justmedia Design, Köln

Alle Rechte vorbehalten. (C) 2012 Max-Planck-Institut für ausländisches und internationales Strafrecht, Freiburg i. Br. 